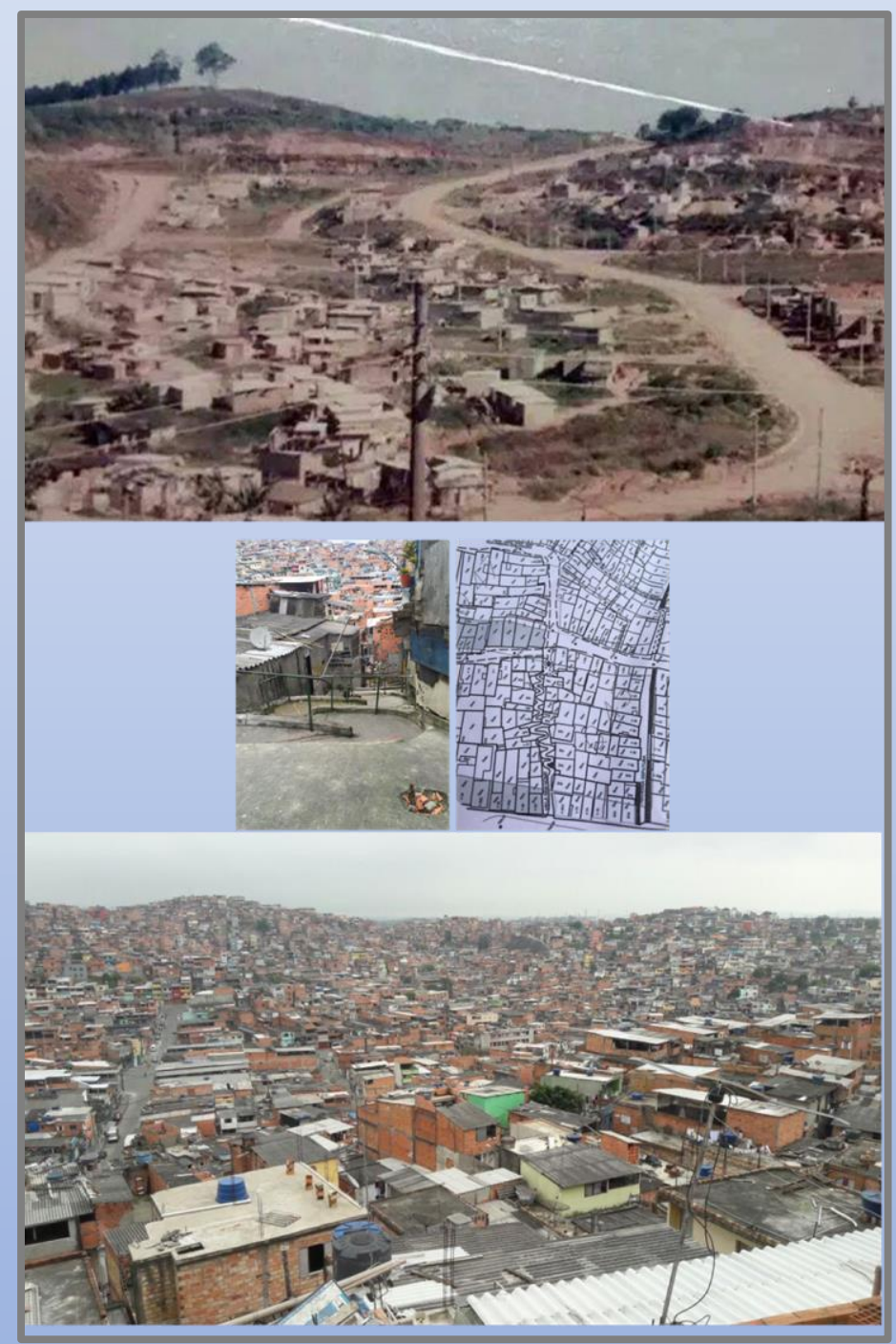

A trajetória e os conflitos da construção legislativa da Regularização Fundiária de Assentamentos Informais

UNIVERSIDADE DE SÃO PAULO

Mestrado em Arquitetura e Urbanismo Faculdade de Arquitetura e Urbanismo FAU

ROSANE DE ALMEIDA TIERNO

Orientação: Profa. Dra. Maria Lucia Refinetti Rodrigues Martins 
Capa: Jardim Paranapanema - Zona Sul de São Paulo, Região do Jardim Ângela. Primeira Imagem: anos 80, formação do assentamento. Segunda Imagem: Detalhe de intervenção de uma viela e seu respectivo levantamento planimétrico cadastral, base do projeto de regularização fundiária. Terceira Imagem: Vista panorâmica do Jardim Paranapanema em 2016. Fontes: Acervo da Associação de Moradores do Jd. Paranapanema e acervo pessoal. 
ROSANE DE ALMEIDA TIERNO

\section{A TRAJETÓRIA E OS CONFLITOS DA CONSTRUÇÃO LEGISLATIVA DA REGULARIZAÇÃO FUNDIÁRIA DE ASSENTAMENTOS INFORMAIS}

Dissertação de Mestrado apresentada à Faculdade de Arquitetura e Urbanismo da Universidade de São Paulo para obtenção de título de mestre em arquitetura e urbanismo.

Área de Concentração: Habitat

Orientação: Profa. Dra. Maria Lucia Refinetti

Rodrigues Martins

São Paulo

2020 
Autorizo a reprodução e divulgação total ou parcial deste trabalho, por qualquer meio convencional ou eletrônico, para fins de estudo e pesquisa, desde que citada a fonte

EXEMPLAR REVISADO E ALTERADO EM RELAÇÃO À VERSÃO ORIGINAL, SOB RESPONSABILIDADE DO(A) AUTOR(A) E ANUÊNCIA DO(A) ORIENTADOR(A).

A versão original, em formato digital, ficará arquivada na Biblioteca da Faculdade.

São Paulo, 20 de julho de 2020

Catalogação na Publicação

Serviço Técnico de Biblioteca

Faculdade de Arquitetura e Urbanismo da Universidade de São Paulo

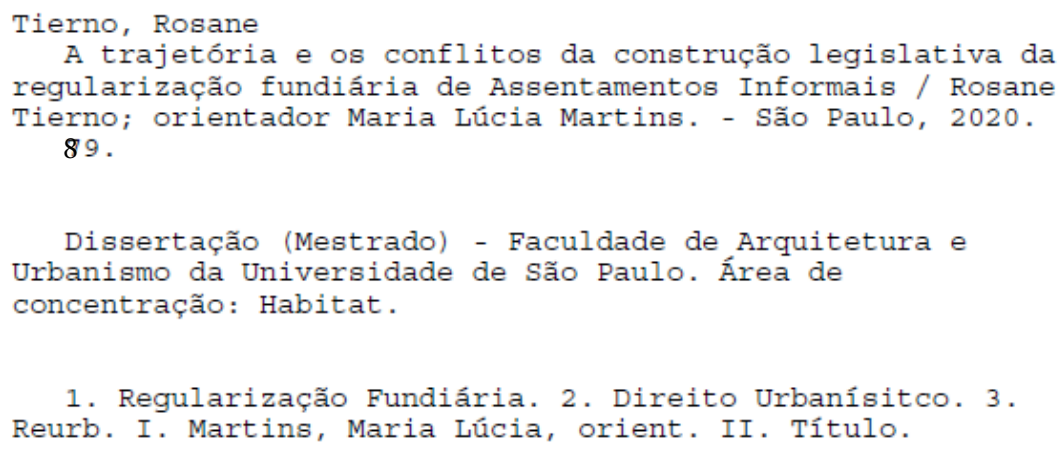




\title{
A TRAJETÓRIA E OS CONFLITOS DA CONSTRUÇÃO LEGISLATIVA DA REGULARIZAÇÃO FUNDIÁRIA DE ASSENTAMENTOS INFORMAIS
}

\author{
Relatório final, apresentado à \\ Universidade Estadual de São Paulo, \\ como parte das exigências para a \\ obtenção do título de mestre em \\ arquitetura e urbanismo.
}

Aprovado em _ _ I I

BANCA EXAMINADORA

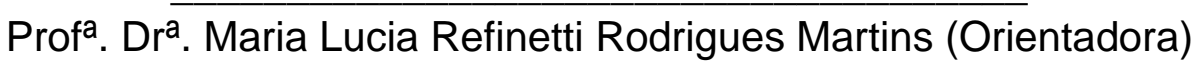

Faculdade de Arquitetura e Urbanismo da Universidade Estadual de São Paulo

Prof. Dr. Celso Santos Carvalho

Escola Politécnica da Universidade Estadual de São Paulo

Prof. Dr. Edesio Fernandes

University College London

São Paulo - SP 


\section{DEDICATÓRIA}

Dedico essa Dissertação de mestrado in memoriam aos meus avós Pelegrino Tierno e Carmen Garcia Domingues Tierno, filhos de imigrantes italianos e espanhóis, respectivamente, primeira geração nascida no Brasil, que afetuosamente me ensinaram que o valor da terra consiste no seu uso efetivo. Em linhas singelas, delinearam o sentido da função social da propriedade, que somente depois de anos, tive a real compreensão de seu alcance. 


\section{AGRADECIMENTOS}

Agradeço à imensa e carinhosa atenção e dedicação de minha orientadora, Maria Lucia Refinetti Rodrigues Martins, e, em nome dela, a todos os pesquisadores do LabHab;

Agradeço ao apoio da querida Betânia Alfonsin, jurista e amiga de todas as horas, e em nome dela, a todos os integrantes do Instituto Brasileiro de Direito Urbanístico IBDU;

Agradeço aos meus dois grandes amigos de caminhada e de LabHab: Renata Lucas e Rodrigo Carvalho Lopes de Souza;

Agradeço a todos os gestores públicos que passaram pela minha vida profissional e me ensinaram empiricamente todos os procedimentos da regularização fundiária;

Em nome da querida Gilvanete Silva, eu agradeço a todos os amigos pelas noites e conversas agradáveis, que me permitiram relaxar a cada intervalo de pesquisas;

Agradeço em especial ao maior incentivador de minha trajetória profissional na área de regularização fundiária, sem o qual eu não teria chegado aqui: Gabriel Blanco;

Agradeço aos meus filhos, Rafaela Tierno Carreta e Enzo Tierno Carreta, pela paciência em relação à enormidade de horas roubadas de seus convívios;

Agradeço às minhas irmãs e sobrinha, Simone Almeida Tierno, Sibelle de Almeida Tierno e Beatriz Tierno Wabeski, que sempre me apoiaram e incentivaram;

E por fim, emocionada, agradeço aos meus pais José Tierno e Rosângela de Almeida Tierno, pelo apoio espiritual e material, colo, abraços, e eterno incentivo à minha vida acadêmica. São meu porto seguro. 
São muitas as iniciativas que têm enfatizado a necessidade da reforma jurídica como condição de promoção da reforma urbana. Entretanto, esse movimento progressista de se repensar o direito, e assim repensar as ideologias do positivismo jurídico e do legalismo liberal que ainda estão na base da ordem jurídico-urbanística, tem sofrido ataques crescentes e gerado fortes reações. Esse é um processo cheio de perigos, na medida em que os avanços e conquistas que têm sido verificados - por exemplo, a aprovação do Estatuto da Cidade $e$ as experiências progressistas de gestão urbana municipal como a de Porto Alegre - não são inquestionáveis. A verdade é que não se pode tomar nada como garantido, porque recuos muito significativos têm acontecido, internacional e nacionalmente.

Internacionalmente, esse processo de construção de um novo paradigma do direito na promoção da reforma urbana tem sido questionado por três movimentos ideológicos inter-relacionados.

O primeiro deles é o avanço da ideologia sem base histórica que tem dado suporte ao movimento de globalização do capital e ao aumento efetivo das trocas no mercado econômico e financeiro global, qual seja, a do neoliberalismo, propondo a flexibilização da ordem jurídico-urbanística sem maiores qualificações e mesmo a desregulação plena; enfim, a retirada do Estado do domínio da 
regulação dos processos de produção econômica e da cidade, inclusive do processo de produção da legislação urbanística que regula as condições de acesso à terra e à moradia. A produção da cidade seria entregue aos processos do mercado, ignorando a verdade histórica de que o mercado por si só não oferece soluções para questões sociais fundamentais, como a questão da moradia social, bem como desconhecendo os processos históricos que mostraram que o crescimento industrial (que foi, inclusive, a razão do processo de urbanização intensiva ao longo do século $X X$ ) se deveu em grande parte a todas as medidas de regulação adotadas pelos diversos Estados nacionais.

Edésio Fernandes 


\title{
RESUMO
}

A presente pesquisa tem por escopo a análise e discussão dos principais marcos normativos que contribuíram direta ou indiretamente para a construção dos atuais normas atinentes à regularização fundiária urbana de interesse social no Brasil, que culminaram para a criação da legislação atual. Efetivamente, a irregularidade fundiária materializa-se ao longo da história como especificidade da forma de produzir territórios nos Brasil, inicialmente no meio rural, e partir da segunda metade do século $X X$, se consolidando na área urbana. Parte-se, assim, da análise da situação fundiária e de legislações que se pretendiam "corretivas", iniciando-se no Período Colonial, daí para o período do Império, da República, e, de forma sistêmica, perfaz-se uma análise que se inicia, com a edição de o Decreto-Lei №. 58, de 1937, passando pelo Decreto-Lei ํo. 271, de 1967, culminando na Lei Federal no. 6766, de 1979. Essas são referências legislativas que indiretamente foram e são aplicáveis à operacionalização da regularização fundiária urbana. Com advento da Constituição Federal, é demonstrada a mudança radical dos paradigmas que formam o novo Estado Brasileiro, com implicações estruturais no mesmo. Com a edição do Estatuto da Cidade e com a criação do Ministério das Cidades, todas as condições estão criadas para marcos normativos específicos: a Lei Federal no. 11.977, de 2009, e, recentemente, a Lei Federal №. 13.465, em 2017. Contudo, essas duas legislações, que aparentemente parecem se assemelhar, como veremos, guardam divergências, que revisitam as estruturas normativas do século XIX, da mesma forma que denotam e acirram o conflito de classe secular no Brasil.

Palavras-chave: Regularização fundiária. Direito urbanístico. REURB.

\begin{abstract}
This research's purpose is to analyze and discuss the main normative frameworks that contributed directly or indirectly to the construction of the current normative frameworks, wich are related to the social interest that dictated (and still dictates) the urban land regularization in Brazil. Effectively, the irregularity of landholdings has taken place, throughout brazilian history, in a much specific way of producing territories. It began in rural zones and, during the second half of the 20th century, it made its path
\end{abstract}


through settling in urban areas. The text starts by analyzing the Colonial Period, the situation of its land ownership and its "corrective" laws, and then does the same historical excercise to the period of the Empire and to the Republic, with the intention to do, later on, a more detailed and sistematic analysis of the "Pre-Urban" period. The latter starts, for methodological purposes, with the edition of the 58th Decree-Law, from 1937, proceeding to the 271 st Decree-Law, from 1967, and finally culminating in the Federal Law $n^{\circ} .6766$, from 1979. These are legislative references that were and still can be applied indirectly to the establishment of the urban land ownership regularization. With the arrival of the Federal Constitution, a radical change in the structural paradigms of the new Brazilian State is demonstrated, also having structural results on itself. Then, when the City Statute was edited and the Ministry of Cities was implemented, all the conditions are there for the creation of specific normative frameworks: the Federal Law no. 11.977, from 2009, and, more recently, the Federal Law no. 13.465, from 2017. Although these two laws may seem similar, we shall see that they have many structural differences, which are related to the normative laws of the 19th century, as well as they denote and intensify the longstanding class conflict in Brazil.

Keywords: Land regularization. Urban law. REURB. 


\section{LISTA DE ILUSTRAÇÕES}

Figura 1 - Jardim das Camélias passa por regularização fundiária 21

Figura 2 - Densidade populacional do município de São Paulo (1940) 23

Figura 3 - Conceitos urbanísticos estabelecidos pelo Decreto-Lei n. $\stackrel{0}{ } 30$ 217 de 1967

Figura $4-$ Características da concessão do direito real de uso 32

Figura 5 - Evolução da população de Diadema e \% da Taxa Geométrica 33 de Crescimento Anual (IBGE)

Figura 6 - Evolução das favelas e da população favelada 33

Figura 7 - Capítulos da Lei №. 6.766 de $1979 \quad 36$

Figura 8 - Íntegra do Projeto de Lei n. 3.057 de 2000 


\section{SUMÁRIO}

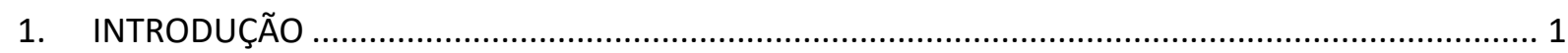

2. ANTECEDENTES: A QUESTÃO FUNDIÁRIA NO BRASIL, DA COLÔNIA À REPÚBLICA ........................ 4

3. NORMAS E REGULARIZAÇÃO FUNDIÁRIA NO BRASIL EM SEU PROCESSO DE URBANIZAÇÃO ..... 21

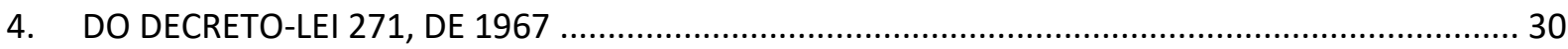

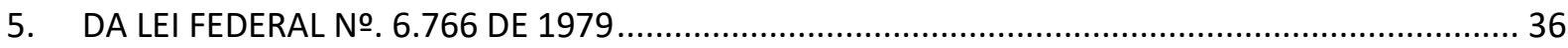

5.1 MUNICÍPIO DE SÃO PAULO COM O ADVENTO DA LEI FEDERAL №. 6.766 DE 1979 .................. 41

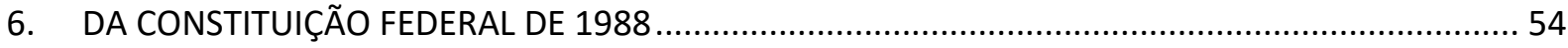

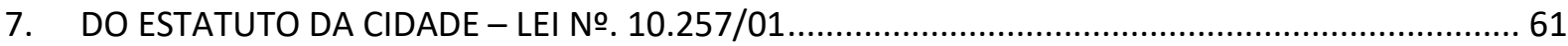

8. DO PROJETO DE LEI DE RESPONSABILIDADE TERRITORIAL URBANA E DO PROGRAMA PAPEL

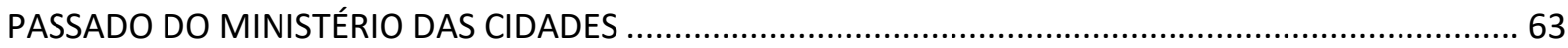

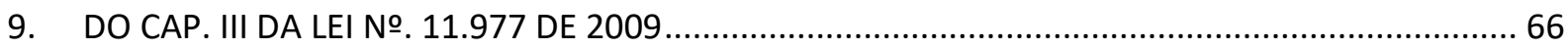

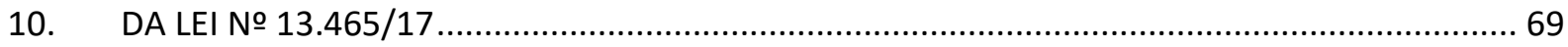

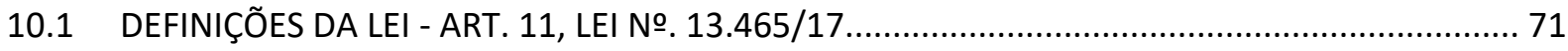

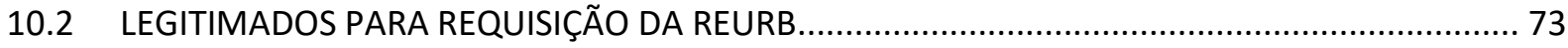

10.3 PROCESSAMENTO ADMINISTRATIVO DO REQUERIMENTO ................................................ 74

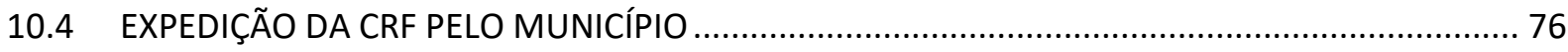

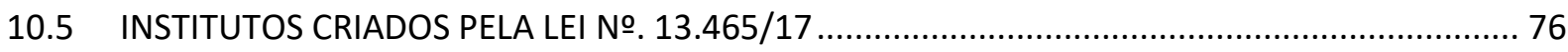

11. CONCLUSÕES

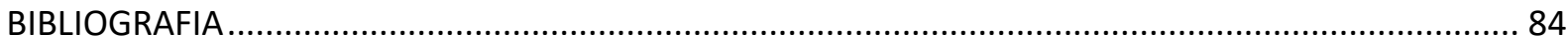




\section{INTRODUÇÃO}

O objeto central do presente estudo é a abordagem da regularização fundiária de assentamentos informais urbanos sob o prisma de sua construção legislativa ao longo das últimas décadas. Contudo, a questão de fundo ao se tratar da regularização fundiária é o próprio objeto territorial da mesma, qual seja, a irregularidade fundiária: suas origens, características, singularidades, abordagem urbanística e legal.

A presente pesquisa foi inspirada na vivência profissional da pesquisadora, que vem atuando no campo jurídico desde a década de 90.

Se por um lado, a nova ordem jurídica urbanística é fenômeno recente, os territórios populares irregulares formam e conformam a estrutura fundiária do país desde sua origem, assim, a ocupação territorial informal, longe de ser uma exceção, é regra na formação dos territórios brasileiros.

Várias razões apontam para as condições propícias ao surgimento dos territórios populares informais: desde a nefasta concentração de renda já no período colonial, como também as produções normativas, que, sob o argumento de disciplinamento da terra (tanto rural como urbana), vem elegendo o privilégio de acesso à terra formal por determinadas camadas social em detrimento de outras.

Dessa forma ocorreu com a edição da Lei de Terras de 1850, da lavra da elite cafeicultora da época, que pretendiam regularizar suas áreas e de manter o monopólio da terra em face à abolição da escravatura e do fluxo de mão de obra imigrante que se avizinhavam. Essas normas determinavam o Registro Paroquial de Terras mediante autodeclaração dos posseiros de terras ao Vigário da paróquia local. A Lei de Terras não determinava qualquer prova de dominialidade ou rigor quanto à especialização da descrição do imóvel, gerando toda sorte de grilagem, cujos efeitos ainda vêm sendo debatidos nos tribunais de modo controverso.

Ainda no século XIX, foram criadas as primeiras normas sobre hipoteca, que somente foram aperfeiçoadas ao longo do século XX, culminando na atual regulação pelo Código Civil de 2002. O aspecto preponderante ao estudo desse instituto procura demonstrar os conflitos e ambiguidades legislativas que culminaram na formação de terras irregulares, incluindo terras urbanas. 
As legislações ambíguas que pretendiam regular o acesso à terra no século XIX, somadas à expressiva desigualdade socioeconômica, presentes no final do século pelos conflitos abolicionistas e pela proclamação da República, marcaram a desigualdade territorial que se acirrou ao longo do século XX. São exemplos destas leis: o Código Civil de 1916, de inspiração napoleônica, editado no início do período republicano, cujo principal objeto tutelado era o patrimônio e sua circulação; o Decreto-Lei №. 58 de 1937, que pretensamente tinha por meta a regulação do mercado de terras parceladas, sob a marca do governo de exceção de inspiração nacionalista de Getúlio Vargas; o Decreto-Lei №. 271 de 1967, também editado em regime de exceção; a Lei №. 6.766 de 1979, ainda sob regime militar, que pontua a atividade de parcelamento do solo como atividade pública, com a União regulando o máximo de aspectos possíveis de sua atividade; chegando ao período democrático iniciado com a Constituição Federal.

A Carta Maior de 88, de forte cunho democrático, introduz uma nova ordem jurídica urbanística, construída a partir intensa participação dos movimento social de moradia, culminando na inclusão da função social da propriedade e de um Capítulo inteiro dedicado à política urbana, com atribuições claras quanto à competência dos entes federativos e elegendo o plano diretor municipal como o instrumento por excelência apto à concretização do planejamento e gestão urbana. A partir daí, iniciase o reconhecimento efetivo das "porções invisíveis" da cidade, com um passivo urbanístico que até a presente data nenhuma legislação e política pública logrou equacionar, malgrado os esforços nesse sentido com a criação do Ministério das Cidades, com toda a reforma legislativa e institucional e com a criação de políticas públicas.

Em 2016, o Brasil sofre uma ruptura no processo democrático com a ascensão da elite econômica ao poder. Com efeito, seguindo a tradição brasileira de medidas de cima para baixo nos momentos de retração democrática, alguns meses após o impeachment presidencial, é editada a Medida Provisória o․ 759, no final de dezembro de 2016, sendo convertida na Lei ㄲo. 13.465/2017, em julho do ano seguinte, cujas consequências ainda estão em curso.

Historicamente, o acesso à moradia para a população de baixa renda no Brasil se deu, em geral, de forma precária configurando-se nas maiores concentrações 
urbanas sob a forma de três tipos básicos de moradia: os cortiços, as favelas e os loteamentos periféricos, com moradia própria e autoconstrução. "Falar de favela é falar das cidades grandes e médias no Brasil no final do século XX e início do século XXI." (PASTERNAK; D'OTTAVIANO, 2016, p. 76).

A presente pesquisa, parte de alguns recortes metodológicos. O primeiro deles, é que se pretende analisar especificamente as legislações que tiveram ou têm impacto sobre as principais aglomerações urbanas em sua configuração a partir metade do século XX, momento em que, no país, a população urbana passa a superar numericamente a rural. Estabelecem regulações que, pouco sensíveis à realidade vigente, colocam na informalidade grande parte do território, ao mesmo tempo em que contêm regras e soluções legislativas que objetivam equacioná-las.

Com efeito, em 1940, a população urbana era de 26,3 \% do total. Em 2000 ela é de $81,2 \%$. Esse crescimento se mostra mais impressionante ainda se lembrarmos os números absolutos: em 1940 a população que residia nas cidades era de 18,8 milhões de habitantes, e em 2000 ela era de aproximadamente 138 milhões. Constatamos, portanto, que em 60 anos os assentamentos urbanos foram ampliados de forma a abrigar mais de 125 milhões de pessoas. Considerando apenas a última década do século $\mathrm{XX}$, as cidades brasileiras aumentaram em 22.718 .968 pessoas. Isso significa mais da metade da população do Canadá ou um terço da população da França. (MARICATO, 2018, p. 16). Hoje se estima que cerca de $84 \%$ dos habitantes do Brasil vivem na zona urbana e apenas $16 \%$ na zona rural.

O segundo recorte metodológico refere-se à perspectiva adotada na pesquisa, que objetiva analisar as normas de acesso à terra, sob o enfoque dos territórios pertencentes à população alijada por essas legislações, e, a partir daí, examinar a produção legislativa editada com as perspectivas de inclusão dessas porções na cidade formal e de garantia da segurança da posse. Centra-se nas trajetórias e conflitos da legislação com incidência na informalidade fundiária e regularização fundiária. Para tanto, optou-se pelo foco na legislação referente a terras privadas, não se aprofundando na análise da gestão de terras de propriedade pública, particularmente as da União, já que contam com características e regulações específicas, o que implicaria em trabalho de pesquisa específico, muito além do escopo ora proposto. 
O terceiro e último recorte metodológico diz respeito à abrangência temporal e territorial da presente pesquisa: o estudo se desenvolve desde as primeiras normas relativas ao acesso à terra como propriedade até o final de 2019. Não obstante a pesquisa se inserir no quadro normativo de âmbito nacional, o foco é na Região Metropolitana de São Paulo, ilustrando aspectos específicos da legislação federal.

Por fim, é fundamental consignar, que o presente trabalho, se de um lado é fruto da busca acadêmica de respostas para a angústia e indagações que emergem de uma prática profissional sempre comprometida, mas fundamentalmente intuitiva, de outro, o levantamento de questões, que se alimenta da pesquisa teórica e documental, não se encerra com a finalização do presente trabalho, haja vista a constante e conflituosa mudança legislativa acerca do tema, que prossegue na busca de reparar com regulação aquilo que estruturalmente a sociedade brasileira insiste em não enfrentar.

\section{ANTECEDENTES: A QUESTÃO FUNDIÁRIA NO BRASIL, DA COLÔNIA À REPÚBLICA}

Decerto, a questão da irregularidade da terra no Brasil é sistêmica, e remete à formação da estrutura patrimonial do estado brasileiro desde suas origens. Como veremos, a magistral gama de normas editadas referentes ao tema da terra, pretensamente objetivaram alguma regulação e controle. Contudo, acabaram por acirrar os conflitos fundiários no que atina à segregação de acesso à terra, perpetuando seus efeitos até os tempos presente.

Iniciando pelo século XIX, a Lei de Sesmarias surge após a Revolução de Avis, em meados do século IV, e fortalece a estrutura fundiária e patrimonialista do Estado Português. Esse modelo instituído por Dom Fernando na Lei de Sesmarias, em Portugal, no ano de 1375, foi transferido e aplicado ao ordenamento de terra na colônia em condições totalmente diversas das existentes em Portugal, produzindo um efeito contrário ao pretendido para as terras portuguesas: a formação de latifúndios. As colônias - e, dentre elas, o Brasil - eram constituídas para fornecer açúcar, tabaco, e alguns outros gêneros; mais tarde o café, para o comércio europeu. Esse aspecto foi determinante para o estabelecimento da estrutura social, bem como as atividades 
econômicas do país. Nessas circunstâncias, as sesmarias assumiram grandes extensões territoriais, constituindo a base do ordenamento da terra para a implantação de monoculturas.

De acordo com Costa Neto (2006), a aplicação da Lei de Sesmarias na distribuição de terras do imenso território brasileiro, no período de 1500 a 1822 , caracteriza uma primeira etapa da acumulação de conflitos e irregularidades no ordenamento e na documentação da terra. A colônia foi estruturada com a extensão do poder patrimonialista da monarquia portuguesa, que manteve o domínio do território por meio do sistema de distribuição de terra em grandes propriedades, por meio da violência que se fazia presente desde a costa africana - pelo mar e interior do continente - e, ainda, por meio da pilhagem em larga escala dos recursos naturais, os quais se transformaram em produtos de venda no mercado europeu. Um dos fatores preponderantes é que a aplicação da Lei de Sesmarias no Brasil foi acompanhada de imprecisões no tamanho e na localização das áreas. Para Silva (1995), as dificuldades de identificação resultaram nas delimitações vagas descritas nas cartas de doação. $O$ estabelecimento formal de limites para as sesmarias foi iniciado no século XVII, com utilização de métodos de medição e demarcação rudimentares, que permaneceram os mesmos até o século XIX (SILVA, 1995).

Note-se que a imprecisão da demarcação de terras serviu para que os donatários pudessem cultivar terras além de suas sesmarias e, assim, se esquivar da gana tributária da coroa. Além disso, a fuga do pagamento de tributos motivou a apropriação informal de grandes áreas florestadas, pois a concessão de sesmarias no Brasil era acompanhada de exigências excessivas e, de tal modo, onerosas, de forma que os sesmeiros abandonavam suas terras para se situarem em terras devolutas, sem título algum, a salvo das obrigações com o governo (LACERDA, 1960, p. 870).

Já no final do século XVII, diversos dispositivos jurídicos foram editados visando a distribuição de terras pela Coroa. A Carta Régia de 1695 instituiu a cobrança de foros na concessão de sesmarias, que foi extinta em 1831 sem estabelecer nenhum efeito prático enquanto importância fiscal. Outros dispositivos, como a fixação da dimensão máxima das sesmarias, pelas Cartas Régias de 1701 e 1729, surgiram da preocupação da Coroa em relação às grandes áreas que vinham sendo apropriadas (SMITH, 1990). Malgrado as tentativas de regulação normativa da 
distribuição de terras da colônia, as investidas da Coroa em estabelecer normas para o ordenamento jurídico da terra no fim do período colonial fracassaram, o que favoreceu a consolidação do regime de apossamento da terra. Com o adensamento da população, os problemas se desdobram em conflitos envolvendo interesses da Coroa, dos sesmeiros - que ocupavam terras sem a legitimação da Coroa - e dos posseiros - que produziam em terras sem documentação.

A incapacidade de adoção de medidas concretas para a definição física das sesmarias, tanto na descrição de limites da documentação referente à concessão quanto na demarcação e fiscalização de divisas em campo, fez com que a consolidação da documentação dos domínios ficasse descolada da realidade existente em campo. Nesse contexto, ocorre o desinteresse dos produtores na formalização e na fixação precisa do limite de domínio de terras, resultando no apossamento de grandes extensões de terras florestadas e na fuga dos encargos impostos pela Coroa.

O período de 1822 a 1891, no qual ocorreu a formulação e a primeira fase da aplicação da Lei de Terras - Lei no. 601, de 18 de setembro de 1850 -, caracteriza uma segunda etapa de acumulação de conflitos e irregularidades no ordenamento da terra, aos quais foram adicionadas irregularidades no registro da propriedade imobiliária. A Resolução de 17 de julho de 1822 e o Ofício de 6 de outubro de 1823 suspenderam a concessão de sesmarias, dando início à fase da grande apropriação de terras no Brasil e da estruturação efetiva do latifúndio com base no poder local, permanecendo o Estado praticamente ausente. Com a dissolução da Constituinte em 1823 por D. Pedro I e com a outorga da Constituição de 1824, a questão da propriedade fundiária deixa de ser abordada, deixando um vazio a respeito do assunto.

O período entre a suspensão da concessão de sesmarias, em 1822, e a promulgação da primeira Lei de Terras do Brasil, em 1850, ficou conhecido - de acordo com Costa Neto (2006, p. 14) - como a fase áurea do posseiro. Em continuidade, o autor também afirma:

Nesse período, alguns fatos relacionados à situação política e socioeconômica, interna e externa ao Brasil, constituem referência para o entendimento da permanência e do agravamento da situação do ordenamento jurídico da terra. 
Em 4 de setembro de 1850, com maioria conservadora, é aprovada a lei que extingue o tráfico de escravos e, em 18 do mesmo mês, a Lei de Terras. Esta lei caracterizou a primeira fase do processo de transição do regime escravocrata para o sistema de trabalho assalariado no Brasil entre os anos de 1840 e 1870, conjugando a perspectiva final do tráfico de africanos à necessidade crescente de mão de obra para a cafeicultura (MENDES, 2009).

BOSI (1988, p. 07), ao analisar semântica e historicamente o termo "liberalismo" na formação do estado brasileiro, aponta para ao sentido do termo a partir de 1850, assinalando que é aquele "capaz de adquirir novas terras em regime de livre concorrência, alterando assim o estatuto fundiário da Colônia no espírito capitalista da Lei de Terras de 1850". Para o autor, o vocábulo se consolida, pela chamada "classe fundadora do império", em prerrogativas econômicas - como o comércio, a produção escravista e a compra de terras - e políticas - como as eleições indiretas e censitárias. Sobre as prerrogativas, "(...) umas e outras davam um conteúdo concreto ao seu liberalismo. Que se tornou, por extensão e diferenciação grupal, o fundo mesmo do ideário corrente nos anos 40 e 50 (BOSI, 1988, p. 07). Assim, o acesso a terras agrícolas passava a se dar exclusivamente por meio de compra e venda, não mais por concessão gratuita em nome do sesmeiro ou do posseiro, como ocorria desde o tempo colonial. De acordo com a Lei no

Art. $1^{\circ}$ : Ficam proibidas as aquisições de terras devolutas por outro título que não seja o de compra. (...) Art. $3^{\circ}$, IV: São terras devolutas: (...) as que não se acharem ocupadas por posse que, apesar de não se fundarem em título legal, foram legitimadas por esta lei. (Brasil, 1850, p. 03).

O objetivo desse dispositivo foi de impedir que imigrantes empobrecidos ou escravos libertos conseguissem adquirir propriedades rurais, mantendo, assim, os privilégios da elite cafeeira como grande proprietária de terras e definindo o papel social do imigrante como mão-de-obra agrícola a se empregar nos latifúndios.

A Lei de Terras veio a ser regulamentada quatro anos depois, por meio do Decreto $\mathrm{n}^{\circ} 1.318$, de 1854 , que propiciou os instrumentos legais para iniciar-se o processo de medição, arrematação e legitimação da propriedade. Com isso, a lei separou as terras de domínio público daquelas de domínio particular, apressou a expulsão dos pequenos posseiros e se revelou, por excelência, como instrumento de concentração da propriedade. Warren Dean, em estudo sobre a cidade de Rio Claro 
(SP), demonstrou que grande parte dos proprietários daquela região, entre 1855 e 1857, não puderam pagar a quantia de 2 a $3 \$ 000$ que importava o registro das propriedades, tendo sido muitos deles expulsos. Outros continuaram a trabalhar em suas antigas terras, cujos domínios foram transferidos para outros donos. Nesse ponto, observa-se que a expulsão da população vulnerável por meio de legislação claramente protecionista do capital não é exclusividade dos séculos XX e XXI, pois já apresentam incidência no século XIX.

Outro aspecto a salientar, o qual gera reflexos jurídicos até a presente data, é o denominado Registro Paroquial, ou Registro do Vigário, que surge com a Lei de Terras. Ele também é regulamentado pelo Decreto ํㅡ. 1.318 de 1854, segundo o qual todos os possuidores de terras, qualquer que fosse o título de sua propriedade ou posse, eram obrigados a registrar as terras que possuíssem no interregno de tempo delineado pela norma junto aos vigários de cada paróquia. O Registro Paroquial de Terras era composto pelos seguintes dados: o nome do possuidor, a designação da freguesia em que estivessem situadas, o nome particular da situação, sua extensão se fosse conhecida - e seus limites.

Alguns autores compreendem que a previsão normativa do Registro Paroquial de Terras configura-se como uma espécie de embrião do princípio da territorialidade do registro, tal como conhecemos pela demarcação das circunscrições competentes para o registro imobiliário (KÜMPEL, 2013). É importante circunscrever que o Registro Paroquial não exigia qualquer prova de domínio da área declarada ou de sua forma de aquisição. Além disso, o Decreto №. 1.318, de 1854 possibilitava, inclusive, a omissão de informações por parte dos declarantes, e até mesmo sua inveracidade, conforme se depreende da leitura do Art. 102:

Art. 102. Se os exemplares não contiverem as declarações necessarias, os Vigarios poderão fazer aos apresentantes as observações convenientes a instrui-los do modo, por que devem ser feitas essas declarações, no caso de que lhes pareção não satisfazer ellas ao disposto no Art. 100, ou de conterem erros notorios: se porêm as partes insistirem no registro de suas declarações pelo modo por que se acharem feitas, os Vigarios não poderão recusa-las. (Brasil, 1854).

Por força da ausência de confiabilidade dos dados contidos nos Registros Paroquiais, severas críticas têm sido efetuadas por historiadores no que concerne à 
quantificação desses dados ou à aproximação com a estrutura fundiária do período. No entanto, estes documentos podem, teoricamente, se prestar como instrumentos de investigação fundiária em uma dada região. Garcia (2011) esclarece que, apesar das omissões e imprecisões apresentadas nas informações dos Registros Paroquiais, essas as características não impedem que tias registros sejam usados para o estudo de estruturas fundiárias. O autor afirma que o impede seu uso para este fim é a natureza da produção da fonte.

Os registros paroquiais, segundo o próprio decreto que os regulamentou: "não conferem direito algum aos possuidores", ou seja, "não foram títulos de propriedade, apenas eram um dos passos a sua consecução" (CRISTILLINO, 2004 , p. 123). Pelo fato e a declaração ao registro ser um ato ao interessado, que muitas vezes revelava uma estratégia de expansão de domínios por parte dos declarantes, esta não é uma fonte apropriada para uma aproximação com a estrutura fundiária do período. Entretanto, segundo crítica feita por Márcia Motta, "muitos historiadores, ao estudarem uma determinada região, quantificaram os dados daqueles que declararam (...) e generalizaram - a partir daí - suas conclusões". (GARCIA, 2011, p. 66).

Com efeito, a questão dos Registros Paroquiais de Terras se encontra distante de estar pacificada. Conforme decisão colacionadas abaixo, podemos inferir com segurança que os tribunais hodiernamente se debatem de forma não unânime sobre a segurança jurídica e natureza de tais títulos:

No ano de 2000 o STF se posicionou diante de uma demanda judicial originada no Tribunal Regional Federal 3ạ. Região - SP, em uma ação de usucapião extraordinário, em que a União se insurgiu alegando que a área tratava de terra devoluta.

(...) As terras, objeto do usucapião, não eram devolutas, posto que adquiridas pela Coroa de Portugal, no início do século XVIII (1.711), como próprio nacional, reservado para povoação em que se cuidava da colonização de indígenas. Com a extinção dos aldeamentos, nos meados do século XIX (1850), as terras foram desafetadas ao fim a que se destinavam e incorporadas aos Próprios Nacionais. III - Pelo Registro Paroquial ㄲo 53, datado de 1856, a área, objeto do usucapião, aparece adquirida por compra e doação, pela Mitra Diocesana de Santos. Também, quando da discriminatória promovida pelo Estado de São Paulo, em 1916, foram 
reconhecidas como particulares as terras da Aldeia de São João do Peruybe e, em 1946 a Mitra vendeu tais terras ao Dr. Leão Novaes, réu no presente feito e cujo domínio foi declarado pela r. sentença recorrida, em nome de seu espólio. IV - A União Federal, que se manteve alheia ao imóvel pelo menos desde o ano de 1856, não pode negar boa-fé ao Registro Paroquial, efetivado de acordo com as solenidades legais, previstas para a época, de molde a tornar inoperante a posse imperturbada da área pela Mitra Diocesana de Santos, sob o argumento de que os bens de seu patrimônio não são usucapíveis. O Código Civil estabeleceu a não usucapibilidade dos bens dominiais da União. Porém, tal diploma legal não atinge direitos adquiridos, caso dos autos, visto que, desde 1856, o imóvel encontra-se na posse do contestante vencedor da ação, por si e por seus antecessores e sucessores e contra o qual nada de consistente se logrou articular. V - A Súmula 340 do C. Supremo Tribunal Federal delimita o tempo a partir do qual não se adquirem tais bens por usucapião, dando pela imprescritibilidade aquisitiva, desde o advento do Código Civil. Contrario sensu, se a prescrição aquisitiva operou-se antes da vigência do Código Civil, impõe-se o reconhecimento do usucapião, mesmo que sobre bens dominiais. VI - No caso, não há dúvida quanto a individualização do imóvel e a sua identificação com a área objeto do registro paroquial, em 1856, como adquirida por compra e doação pela Mitra Diocesana, que, em 1946,viria a vendê-la ao Sr. Leão Novaes. Desta forma, mesmo que se reconheça ao registro paroquial apenas valor de prova de posse declarada e não impugnada, esta é idônea para assinalar, na sua data, o termo inicial da prescrição aquisitiva quarentenária, indiscutível, se consumada antes do Código Civil VII (...). (STF, 2000, on-line, grifo nosso).

Contudo, como já informado, essa não é a posição majoritária de nossos tribunais a respeito do Registro Paroquial. Recentemente, o posseiro de uma ilha em Santa Catarina ingressou com ação judicial junto ao Tribunal Regional Federal da $4^{a}$. Região visando adquirir a propriedade plena da mesma com fundamento em uma ampla cadeia dominial, que se originava em Registro Paroquial. Contudo, ele teve seu pleito indeferido pelo Superior Tribunal de Justiça em 2009, sob o seguintes fundamentos articulados pela $4^{\mathrm{a}}$ turma do STJ:

O autor da ação alegou ser dono da ilha desde 1953, conforme escritura pública de compra e venda, registrada em cartório. Em 1990, julgando abusiva a taxa de aforamento cobrada, ele encaminhou petição à Delegacia do Patrimônio da União no estado - órgão da Secretaria de Patrimônio da 
União, vinculada ao Ministério do Planejamento - para que houvesse reconhecimento do domínio pleno sobre a ilha. O pedido foi indeferido porque, segundo o órgão, não estava provada a cadeia sucessória e a alienação das terras pela União. $O$ órgão superior manteve a decisão e acrescentou que o registro feito no livro do vigário em Porto Belo, para legitimar a propriedade, era um simples cadastro. $\mathrm{O}$ ocupante da área recorreu, alegando que a Lei de Terras - a Lei 601 de 1850 - legitimou a posse de João da Cunha, primeiro proprietário, sobre a terra, e que ele levou o imóvel ao registro paroquial, o qual, segundo o autor da ação, comprova a titularidade do domínio. $\mathrm{O}$ juízo da $4^{\mathrm{a}}$ Vara da Circunscrição Judiciária de Florianópolis julgou improcedente o pedido. O ocupante da ilha recorreu ao STJ, alegando que houve violação da Lei de Terras (...). Por unanimidade, porém, os ministros não acolheram o recurso, seguindo as considerações do relator, ministro Luis Felipe Salomão. Ele afirmou que a cadeia dominial do imóvel não é completa porque haveria nos autos apenas indícios de que João da Cunha tentou legitimar a posse. Segundo o relator, o registro paroquial não tem o poder de atribuir o domínio ao ocupante da terra, pois não confere publicidade aos registros. (...) Quanto à questão de o registro paroquial dar direito de propriedade, o ministro Luis Felipe Salomão argumentou que, por qualquer ângulo que se analise a questão, seja considerando-o apenas como cadastro estatístico ou simplesmente meio de prova do fato da posse, não há como conferir o alcance pretendido, já que esse registro não pode completar a cadeia dominial, viciada desde a origem. (STJ, 2009, on-line, grifo nosso).

Como se pode concluir, é legítimo supor que as consequências das disposições imprecisas e ambíguas contidas na Lei de Terras, de 1850, ainda vêm sendo objeto de celeumas jurídicas e de imprecisões quanto à sua dominialidade, repercussões estas que transpassam os séculos XIX e XX, se mantendo, ainda, no século XXI.

Entretanto, alguns estudos feitos apontam para a relevância da edição da Lei de Terras de 1850, que ocorreu no sentido de determinar que ex-escravos - pois, por pressão da Inglaterra, previa-se que o fim da escravatura estaria próximo. Ledo engano! -, e imigrantes europeus de baixa renda não se tornassem proprietários de terras. Isto foi realizado de modo a garantir mão de obra farta e barata por alguns anos àqueles latifundiários cafeicultores que, graças à Lei de Terras, passaram a monopolizar as propriedades fundiárias legais no Brasil Império, mesmo que a origem das mesmas tenha se dado por meios obscuros. Nesse sentido, Gadelha (1989) 
afirma que a Lei de Terras se mostra urgentemente fundamental, porém tendo seu foco deslocado da questão fundiária em si para a necessidade de substituir a mão de obra dos escravos, que eram considerados apenas instrumentos de trabalho - ao invés de serem vistos como trabalhadores.

Procurava-se, assim, contrabalançar os efeitos da abolição, incentivando a colonização através da possibilidade que teriam os colonos imigrantes, da aquisição de lotes de terras devolutas. Possibilidade que se apresentaria com o retalhamento dos terrenos pertencentes ao Estado, em pequenas propriedades, tomadas acessíveis à poupança dos colonos, após alguns anos de trabalho nas lavouras de proprietários que os pudesse remunerar. (GADELHA, 1989, p. 09).

Com isso, a venda destes lotes - que eram propriedades do Estado e, posteriormente, foram divididos em pequenas porções de terra concedidas aos colonos - serviriam como incentivo à colonização e, assim, assegurariam a abundância de mão de obra barata, dado que, por vezes, os trabalhadores que eram filhos de ex-escravos mas nasceram em liberdade eram desprezados como força de trabalho assalariada. Em seguida, o autor esclarece:

Marcam o início da era capitalista no Brasil dois diplomas: $\left.1^{\circ}\right)$ A Lei que aboliu o Tráfico (04/09/1850); 2º) A Lei de Terras ํํ 601 (18/09/1850).

Era finalidade principal da Lei de Terras "destruir as antigas formas de apropriação do solo". O fato é que a terra, até então, quase nenhum valor possuía entre nós. "A terra deve adquirir valor e os proprietários renda", argumentava o Deputado Barbosa, representante do Rio de Janeiro, porém, no sistema, para explorar e dominar o trabalho.

A Lei fixaria, portanto, o preço da terra para os posseiros, mas desconsideraria os roçados simples como característica da posse. Restringia-se, assim, a possibilidade da pequena propriedade, preservandose, ao mesmo tempo, a estrutura da propriedade.

Quanto aos escravos - e a Lei alegava também a necessidade de substituição dos braços escravos -, tratava-se de resolver o novo fator de irracionalidade que atingira o sistema escravagista, encarecendo o custo do escravo e de sua exploração, consequência maior da abolição do tráfico africano. Porém, os objetivos capitalistas dos proprietários só seriam alcançados se o acesso do solo aos ex-escravos e aos trabalhadores nativos fosse dificultado. 
Assim, conforme a Lei de Terras, os trabalhadores tiveram que ser: $1^{\circ}$ ) Afastados da terra e dos meios de subsistência; $2^{\circ}$ ) Afastados da propriedade desses meios. Num país em que a posse representava não somente o meio mais fácil de ocupação do solo, como também, a única forma de subsistência do homem livre não proprietário, restringia-se a possibilidade de existência da pequena propriedade, preservando-se a estrutura latifundiária da terra.

Digressões como esta são fundamentais para compreendermos a questão da ausência de solo regular destinado à massa da mão de obra, que foi substancialmente acompanhada pelo processo de urbanização do país a partir da segunda metade do século XX. Neste momento, por efeito acumulativo, a massa de ex-escravos "semterra" passa a ocupar os centros urbanos nas mesmas condições fundiárias de meados do século XIX, quais sejam, sem acesso à terra, essencialmente porque o processo de abolição da escravatura não foi seguido de qualquer reparação material.

Vejamos aqui outros objetivos da Lei oㅡ 601 , de 1850, os quais nos interessam particularmente. Primeiramente, a lei garantiu o domínio de todo possuidor de terra que tivesse título legítimo de aquisição. Em segundo lugar, ela definiu normas não somente para a revalidação das terras possuídas por títulos de sesmarias e outras concessões do Governo Geral Provincial, como também para a legitimação de posses mansas e pacíficas adquiridas por ocupação primária, ou havidas do primeiro ocupante. A revalidação e a legitimação dessas terras estavam condicionadas à medição e à demarcação dentro de prazos a serem estabelecidos pelo Governo (COSTA NETO, 2006). Entretanto, estes domínios, mesmo sendo cultivados e servindo como morada habitual dos titulares, não haviam cumprido com as condições legais da respectiva concessão anteriormente citadas.

Sem dúvida, a Lei de Terras de 1850, pode-se dizer, pretendeu ser uma das primeiras normas de regularização fundiária do país. Conforme Tierno (2019):

(...) Guardadas as devidas proporções históricas, podemos asseverar que a legitimação trazida pela Lei de Terras de 1850 a caracterizava como clara legitimação de posse, na medida que pressupunha o reconhecimento do Império do exercício da posse por seus titulares. Vejamos o disposto sobre a matéria na Lei ํo. 601/50:

Art. 5o Serão legitimadas as posses mansas e pacíficas, adquiridas por occupação primaria, ou havidas do primeiro occupante, que se acharem 
cultivadas, ou com princípio de cultura, e morada, habitual do respectivo posseiro, ou de quem o represente, guardadas as regras seguintes:

§ $1^{\circ}$ Cada posse em terras de cultura, ou em campos de criação, comprehenderá, além do terreno aproveitado ou do necessario para pastagem dos animaes que tiver o posseiro, outrotanto mais de terreno devoluto que houver contiguo, comtanto que em nenhum caso a extensão total da posse exceda a de uma sesmaria para cultura ou criação, igual ás ultimas concedidas na mesma comarca ou na mais vizinha.

$\S 2^{\circ}$ As posses em circumstancias de serem legitimadas, que se acharem em sesmarias ou outras concessões do Governo, não incursas em commisso ou revalidadas por esta Lei, só darão direito à indemnização pelas bemfeitorias.

(...) Art. 6ำ Não se haverá por principio do cultura para a revalidação das sesmarias ou outras concessões do Governo, nem para a legitimação de qualquer posse, os simples roçados, derribadas ou queimas de mattos ou campos, levantamentos de ranchos e outros actos de semelhante natureza, não sendo acompanhados da cultura effectiva e morada habitual exigidas no artigo antecedente. (TIERNO, 2019, p. 431, grifo nosso).

Nesse sentido, o instituto da legitimação de posse - que, podemos inferir, assumiu conotação e aplicabilidade similar na Lei n․ 11977 de 2009 nas áreas urbanas, como veremos adiante - pode ser compreendido como o primeiro instrumento de regularização fundiária do Brasil já em 1850, conforme apontado por Magalhães (1997):

Nisto creio que se resume o primeiro momento da evolução do instituto da legitimação de posse, um instituto que não foi feito para durar, mas, precisamente para desaparecer, posto que se resolvia com a titulação dominial dos que a requeressem. Ao cobrir as posses existentes com o manto da legalidade, fazendo com que passassem do plano empírico ao plano jurídico (vale dizer, ao exercício de poderes jurídicos conferidos a particulares observadas certas condições formais prescritas em lei), a Lei de Terras promove a primeira "Regularização Fundiária" de que se tem notícia em nossa história, sendo certo que esta consiste precisamente no processo pelo qual busca-se trazer aquele que encontra-se em situação precária, instável, anormal e irregular em sua relação com a terra de que se utiliza, para o mundo da certeza, previsibilidade e estabilidade do ordenamento jurídico, o que se processará por meio de sua titulação como proprietário - ou, na pior 
das hipóteses, como detentor de um direito real, portanto, derivado da propriedade. (MAGALHÃES, 1977, on-line).

Com o fim do império, algumas terras devolutas passaram ao domínio público dos estados. Outras legislações a nível federal vieram a tratar da matéria com outros contornos, tais como: o Decreto no 19.924 de 1931, que trata das terras devolutas; 0 Decreto-Lei no $9.760^{1}$ de 1946, que dispõe sobre terras da união; o Estatuto da Terra (Lei Federal no 4.504 de 1964²); a Lei Federal no. 6.383 de 1976, que dispõe sobre o processo discriminatório de terras devolutas da União; e a Lei Federal no 9.636 de 1998, que dispõe sobre a regularização, administração, aforamento e alienação de bens imóveis de domínio da União.

Conforme consignado por Costa Neto, a edição de normas fundiárias visando o disciplinamento fundiário se reproduzirá em diversos momentos da nossa história, de maneira cíclica: a expedição de leis que buscam a resolução de problemas relacionados ao ordenamento da terra ou à execução de trabalhos técnicos de mapeamento, demarcação e cadastramento de terras foram condenadas ao fracasso. No mesmo sentido - sobre o imbróglio fundiário no Brasil, que ainda hoje se configura como o "nó da terra" - Maricato (2002) com propriedade, afirma:

Os conflitos sociais que marcam todo o século XIX revelam a forte e evidente relação que articula acesso à terra, mão-de-obra e colonização. O latifúndio resiste, mais de quatro séculos, a todos os debates e propostas de mudança. O processo de urbanização será marcado fortemente por essa herança. Embora a urbanização da sociedade brasileira se dê praticamente no século $\mathrm{XX}$, sob o regime republicano, as raízes coloniais calcadas no

\footnotetext{
1 Posteriormente alterado pela Lei Federal №. 11.481, de 2007, que incluiu dispositivos específicos sobre regularização fundiária de interesse social e que foi, em parte, incorporada à Lei Federal ํㅡ. 11.977, de 2009.

${ }^{2}$ Curiosamente, essa Lei, que foi editada em regime político de exceção, já dispôs sobre a função social da propriedade em seu art. $2^{\circ}$ :

É assegurada a todos a oportunidade de acesso à propriedade da terra, condicionada pela sua função social, na forma prevista nesta Lei.

$\S 1^{\circ} \mathrm{A}$ propriedade da terra desempenha integralmente a sua funcão social quando, simultaneamente: a) favorece o bem-estar dos proprietários e dos trabalhadores que nela labutam, assim como de suas familias;

b) mantém níveis satisfatórios de produtividade;

c) assegura a conservação dos recursos naturais;

d) observa as disposições legais que regulam as justas relações de trabalho entre os que a possuem e a cultivem. (Grifo nosso).
} 
patrimonialismo e nas relações de favor (mando coronelista) estão presentes nesse processo. A terra é um nó na sociedade brasileira... também nas cidades. A legislação é ineficaz quando contraria interesses de proprietários imobiliários ou quando o assunto são os direitos sociais. (MARICATO, 2002, p. 15).

Outro instituto importante, criado e regulamentado diversas vezes no século XIX é a hipoteca. A relevância da análise desse instituto cível para este trabalho deve ser circunscrita pelas consequências da imprecisão que a cadeia dominial gerou, criando um imbróglio jurídico até os dias atuais, como veremos adiante.

Com a Lei no 317 de 1843 foi criada a hipoteca, por meio de um singelo dispositivo incluído nesta lei, cujo objeto principal era a fixação da despesa e o orçamento da Receita para os exercícios de 1843-1844 e de 1844-1845: "Art. 35 Fica creado um Registro geral de hypothecas, nos lugares e pelo modo que o Governo estabelecer nos seus Regulamentos." (Brasil, 1843).

Em 1846, a Lei no. 317 foi regulamentada por meio do Decreto № 482 de 1846, que estabeleceu o regime geral das hipotecas, arrolando os legitimados para requerer o registro, os locais e as formas: "Art. 4ํㅡㄹ Deverão ser registradas no Cartorio do Registro geral todas as hypothecas convencionaes, quer geraes, quer especiaes." Este regulamento também previu o disciplinamento geral das hipotecas - ou seja, atos de registro e averbação, além de cartórios competentes para a prática de cada ato -, bem como o registro de hipotecas de toda variedade de bens patrimoniais, inclusive hipoteca de escravos:

Art. $2^{\circ}$ As hypothecas deverão ser registradas no Cartorio do Registro geral da Comarca onde forem situados os bens hypothecados. Fica porêm exceptuada desta regra a hypotheca que recahir sobre escravos, a qual deverá ser registrada, no registro da Comarca em que residir o devedor. (Brasil, 1846).

Por sua vez, o Código Comercial de 1850 ampliou a regulação das hipotecas. $\mathrm{Na}$ sequência, foi editada a Lei no 1.237 de 1864, dispondo sobre a reforma da Legislação Hypothecaria e estabelecendo as bases das sociedades de crédito real. Essa lei foi regulamentada pelo Decreto no 3.453, de 1865, também chamado de Registro Geral ou de Registro de Hipotecas. Por meio dessa lei tornou-se obrigatória 
a transcrição dos contratos de transmissão de propriedade nos cartórios de Registro Geral, para que a operação tivesse segurança jurídica e para que também fosse possível a emissão de certidões negativas de alienação. Estas últimas interessavam aos capitalistas que operavam com hipotecas, gerando efeito multiplicador sobre as vendas de terras às elites da época. Importante salientar que, embora a medida gerasse publicidade ao negócio, a transcrição não tinha por efeito prova de domínio. Contudo, ela ampliava a segurança negocial.

Por meio da Lei no 3.272 de 1885 tornou-se obrigatória a inscrição de todas as hipotecas, inclusive as legais. Embora a regulação do instituto da hipoteca se iniciou no século XIX, sua regulamentação ocorreu somente com o advento do Código Civil de 1916, sendo aperfeiçoada pela Lei dos Registros Públicos - Lei no 6.015 de 1973 - que especificou o tratamento da hipoteca no Registro de Imóveis e criou a matrícula imobiliária. Finalmente, foi normatizada pelo Código Civil de 2002, atual norma regulamentadora da hipoteca no Brasil.

Contudo, importa consignar que o disciplinamento do instituto da hipoteca no século XIX gerou efeitos nefastos ao mosaico fundiário das terras ali transcritas, resultando em insegurança jurídica e propiciando grilagem de terras. Isto, inclusive, ocorreu com terras urbanas, como bem esmiúça a questão Holston (1993) ao analisar as origens fundiárias de assentamento informal na zona leste de São Paulo, no Jardim das Camélias. O autor começou a analisar pelo ano de 1890, quando o governo republicano concedeu ao engenheiro Ricardo Medina 50 mil hectares de terras devolutas divididas em duas partes iguais - cada qual em uma das margens do rio Tietê, no leste de São Paulo - sob algumas obrigações. São elas: fundar, num período de dois anos, uma colônia agrícola com 500 famílias de cada lado do rio; fazer um levantamento da área a fim de discriminar as terras devolutas daquelas já adquiridas por outros, e sobre as quais ele não tinha direitos; e pagar um preço fixo pelas primeiras, as quais poderia revender aos imigrantes, tudo isso sob pena de reversão ao governo.

Em 1891, Medina transferiu sua concessão, com todas as suas condições, para o Banco Evolucionista do qual era o fundador e que era um dos muitos precários bancos de empreendimentos imobiliários que surgiram com a nova política de terras. 
O banco não conseguiu colonizar as áreas no tempo exigido e, com isso, perdeu o contrato. Ele conseguiu, no entanto, fazer um levantamento da parcela mais ao sul e chegou a oferecer pagamento por ela, mas não discriminou, dentro dessa parcela e muito significativamente, as terras devolutas daquelas que não eram. Nestas condições, em 1892, o governo republicano concedeu ao banco o título de 25 mil hectares. Apesar de isso estabelecer os direitos de propriedade do banco, as terras ficavam subordinadas a todas as condições estipuladas na concessão original. Um ano mais tarde, o Banco Evolucionista hipotecou esse título condicional ao Banco de Crédito Real do Brasil, o qual ficou definitivamente com o título quando o primeiro foi à falência em 1900. Apesar do Banco de Crédito Real também ter falido em 1909, seu presidente, Eugênio Hanold, comprou o título em leilão realizado durante a liquidação do banco. Vendeu-o em 1917 para a Predial, uma companhia imobiliária. Nesse interregno, todavia, outros credores do Banco Evolucionista entraram com processos pedindo as partes das propriedades do banco que Ihes cabiam. O estado de São Paulo também interveio, alegando que ele, e não o banco falido, de acordo com a Constituição de 1891 , detinha as terras devolutas em questão. $\mathrm{O}$ caso foi para 0 Supremo Tribunal Federal.

Todavia, sua decisão em 1928 mais pareceu complicar do que resolver a disputa: apesar de o Supremo reafirmar a validade dos direitos do Banco Evolucionista, negando que a Constituição os havia esvaziado, ela estabeleceu, com base na cláusula da reaquisição - constante no contrato inicial de 1890 - que o estado de São Paulo tinha direitos sobre a metade dos 25 mil hectares. A Corte definiu o Estado, e não a União, o beneficiado com a devolução da propriedade, argumentando, para tanto, que na época em que o banco rompeu o contrato já estava em vigor a Constituição que determinava que as terras devolutas eram dos estados. Assim, o Supremo Tribunal Federal reconhecia que o banco e o Estado tinham, cada um, direito sobre 12.500 hectares, os quais estavam sujeitos à mesma condição original, qual seja, a discriminação das terras devolutas daquelas que não o eram.

A decisão judicial gerou, entre outros, dois efeitos importantes: Primeiro, ela deu o fundamento originário aos interesses de propriedade do estado de São Paulo em lugares como o Jardim das Camélias. Segundo, ela possibilitou o reconhecimento do título do banco por parte do Supremo, e, apesar de o documento valer apenas 
para a metade da área total anteriormente compreendida, permitiu que seus herdeiros continuassem a usar esse mesmo título em transações bancárias e comerciais. Porque as terras nunca foram claramente discriminadas e porque havia muitos herdeiros, o título foi envolvido sempre de maneira ambígua, às vezes de modo fraudulento em inúmeras transações. Assim, em 1958, quando a Predial o vendeu para Nagib Jafet, um ex-presidente da Adis, constava no contrato uma cláusula que dizia o seguinte: "o vendedor não é responsável por qualquer perda de direitos". Nesse mesmo espírito, em 1966, Jafet vendeu para Garzouzi que, por sua vez, em 1968, assim que se tornou seu único acionista, transferiu-o para a Adis.

Dessa maneira, ao longo de todo um século, uma infinidade de bancos, firmas imobiliárias e terceiros estiveram utilizando-se desse título para completar várias transações de propriedades - algumas envolvendo o próprio título juntamente com outras tantas terras de fato, mas todas, fundamentalmente, comprometidas por sua natureza condicional. Os negociantes desse quase fetiche dependeram de dois fatores para levar adiante sua transação: fraudes e o acúmulo de complicações que permeavam o título. Sua força vem de sua complexidade, a qual impossibilita aos Tribunais resolver uma das disputas sem resolver todas as outras. Como isso é praticamente impossível, nunca declararam o esgotamento da validade do título. É dessa maneira que se multiplicam as oportunidades para a prática da grilagem. A única solução é regularizar, através de intervenção extrajudicial, todo hectare citado no título, de tal forma que esse mesmo título perca seu poder - já que, assim, fica sem objeto, a saber, terras devolutas ou de posse duvidosa. A comissão de procuradores do Estado convocada em 1986 para examinar o problema chegou exatamente a essa conclusão, encomendando nada menos que um decreto presidencial para resolver as disputas de terras no Jardim das Camélias.

Em continuidade, Holston consegue demonstrar o processo pouco idôneo que todo esse procedimento gerou:

Ao investigar a perpetuação do título do Banco Evolucionista, encontrei dezesseis tipos diferentes de fraudes. Algumas são gritantes, como a falsificação de documentos, adulteração de marcas de divisões, corrupção de funcionários e destruição de registros. Outras são sutis, estratagemas de longo prazo que se utilizam da lei para estabelecer precedentes a favor do 
grileiro. Por exemplo, um grileiro se utiliza de documentos falsos, relativos a um pedaço de terra, para abrir um processo para reaver sua posse; um cúmplice, todavia, faz as vezes de ocupante ilegal. Ele se defende de maneira pouco convincente e é expulso da terra. Resultam disso tudo muitas ações no Tribunal e uma série de precedentes constituindo uma espécie de jurisprudência, a qual o grileiro apresentará mais tarde para sustentar suas alegações de propriedade. A fraude mais impressionante, contudo, talvez tenha ocorrido justamente quando tudo começou. Ao executar a hipoteca do Banco Evolucionista, o Banco de Crédito Real alegou ter adquirido com isso um imóvel especificado em uma "carta de adjudicação" extrajudicial. O problema é que a hipoteca só podia se referir a possíveis direitos sobre hectares ideais, e não a direitos reais sobre terras discriminadas um detalhe que, de minha perspectiva, condena tanto as alegações de propriedade da União quanto as do Estado. No entanto, a referida "carta" incluía um levantamento que definia uma área de 21.600 hectares. Essa transformação mágica do ideal em real é um exemplo de um tipo de trapaça envolvendo a hipoteca um tanto quanto comum entre grileiros bem relacionados. De um jeito ou de outro, o grileiro acaba obtendo documentos que the dão direito sobre terras ideal ou vagamente definidas. Ele então as hipoteca a um parceiro como garantia de um empréstimo que, deliberadamente, não é cumprido. Como a execução da hipoteca requer um inventário de bens, o parceiro contrata um inspetor para produzir um levantamento da propriedade hipotecada, o qual, todavia, é impossível de ser verificado em função de sutis omissões técnicas. Esse levantamento torna-se parte de uma carta de acordo privado ou de leilão para a liquidação da dívida, a partir da qual a negociação é resolvida juridicamente. Como os documentos são agora parte de um procedimento judicial, os grileiros têm pouca dificuldade para obter a escritura das terras estas que talvez nem existam, mas que foram por eles definidas a partir de uma rede de operações perfeitamente legais. Nos documentos da Adis e de seus predecessores, esse tipo de alquimia envolvendo hipotecas, cartas de acordos e levantamentos aparece sistematicamente na origem de suas alegações. (HOLSTON, 1993, p. 82-83).

Quanto ao status fundiário do Jardim das Camélias, em 2016 se teve notícias que estava em processo de regularização fundiária pela SEHAB - Secretaria de Habitação de São Paulo, pasta da Prefeitura do Município de São Paulo, conforme matéria divulgada na imprensa em 31 de março de 2016, demonstrando os efeitos tardios de uma política fundiária marcada por legislações ineficientes. 
Figura 1 - Jardim das Camélias passa por regularização fundiária

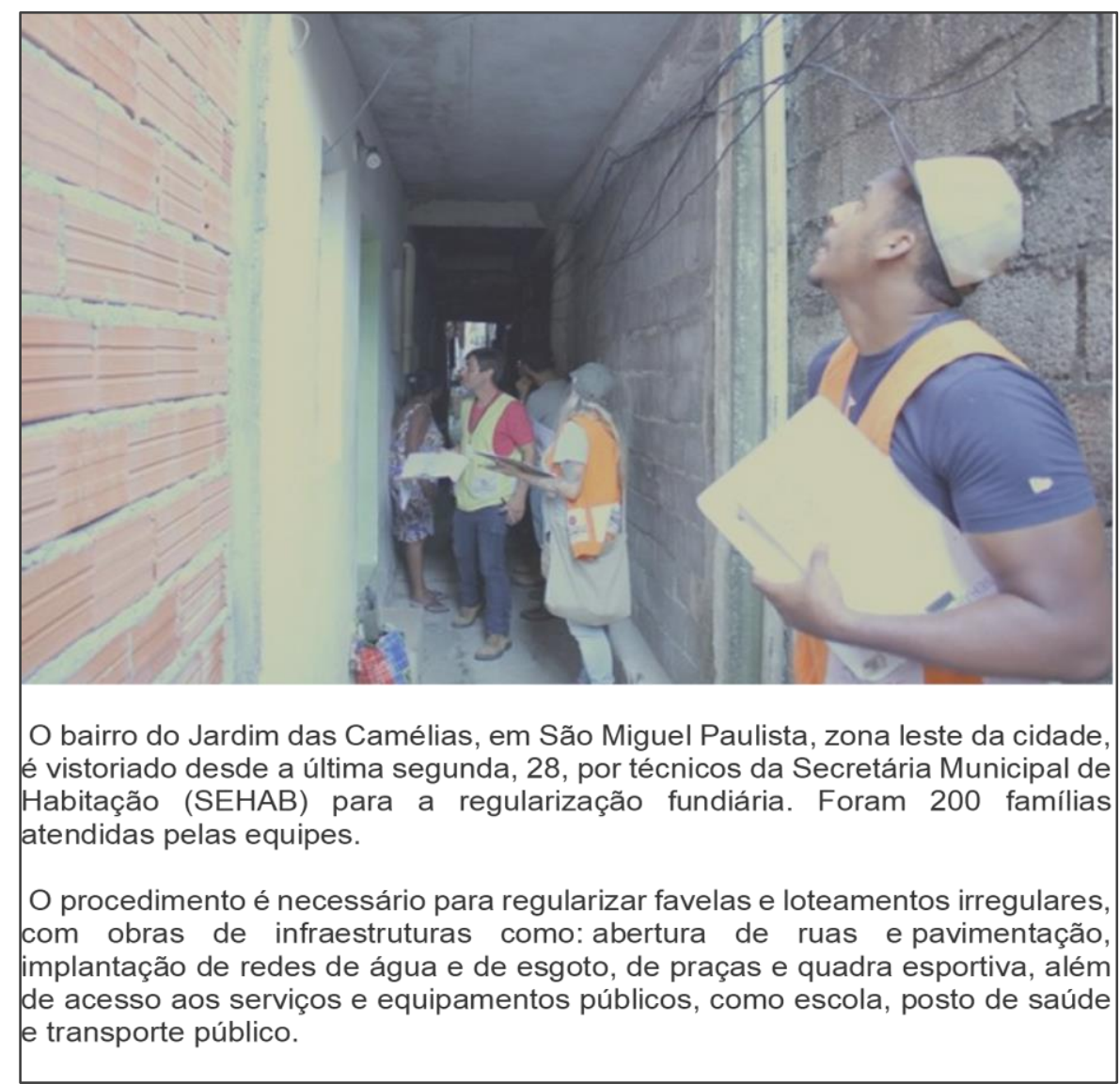

Fonte: http://www.centrallestenoticias.com.br/alro/noticia/sao-miguelpaulista/3258/jardim-das-camelias-passa-por-regularizacao-fundiaria-

Como veremos ao longo da presente dissertação, o ciclo do (in)disciplinamento fundiário referido por Costa Neto (2006) se repete hodiernamente no Brasil, retroalimentando e tornando rijo o atamento do nó da terra (MARICATO, 2002), célebre alegoria que representa cabalmente as tentativas e fracassos das inciativas legislativas pertinentes à questão fundiária no Brasil.

\section{NORMAS E REGULARIZAÇÃO FUNDIÁRIA NO BRASIL EM SEU PROCESSO DE URBANIZAÇÃO}

A nova era da república e a pujança da economia cafeeira promoveram profundas transformações no campo, com reflexos de monta na cidade. A formação predominantemente edilícia de taipa de São Paulo, construída por escravos, passa a ser substituída gradativamente por palacetes, construídos sob encomenda por 
trabalhadores livres italianos. Conforme Tone e Ferrara, a produção urbana passa a ser tornar altamente rentável,

(...) com fundamentos no monopólio da propriedade da terra e na produção manufatureira no canteiro de obras, além de constituir forma de domínio social. Com o crescimento dessa produção para o mercado, o trabalhador italiano bem remunerado foi gradualmente substituído pela classe operária da construção civil em formação, mediante conflitos entre classes sociais; as figuras do proprietário e do empreiteiro-construtor uniam-se, pressionando o salário do trabalhador. (TONE; FERRARA, 2011).

A desigualdade sócio territorial assolava os centros urbanos da República recente, de tal modo que uma das poucas modalidades de moradia para a população de baixa renda - formada especialmente por imigrantes europeus pobres, escravos e seus descendentes - eram as vilas operárias e habitações operárias, os cortiços e outras formas de habitação coletiva. Tais condições nas quais moravam os pobres eram abundante na Capital e em São Paulo, por exemplo.

A crise habitacional brasileira se tornou mais preponderante a partir das décadas de 30 e 40 do século XX. Como apontado por Martins (2006) vários fatores desencadearam o agravamento da crise habitacional da classe trabalhadora em São Paulo. Por exemplo: obras do Plano de Avenidas do Prefeito Prestes Maia, ocasionando a demolição de numerosas residências, a expulsão da população e também o aumento do preço dos terrenos das regiões envoltórias dessas obras; e os efeitos da lei do inquilinato de 1942, que, ao congelar os preços dos alugueis, diminuiu a disponibilidade de habitações

(...) retraindo o mercado de habitações de aluguel e ampliando o de compra e venda. Para a maioria da população, cuja renda era insuficiente para aquisição de imóveis em áreas centrais, tornou-se impossível também o aluguel, restando a possibilidade de a casa própria autoconstruída em loteamentos periféricos. (MARTINS, 2006, p. 56-57).

Documento igualmente interessante foi produzido pelo geógrafo Pierre Monbeig. Ele, na época professor da USP (membro de missão francesa) realizou vários estudos sobre o crescimento da cidade de São Paulo e nos legou alguns mapas demográficos, como o que segue (OLIVA; PADOVESI, 2016). 
Figura 2 - Densidade populacional do município de São Paulo (1940)

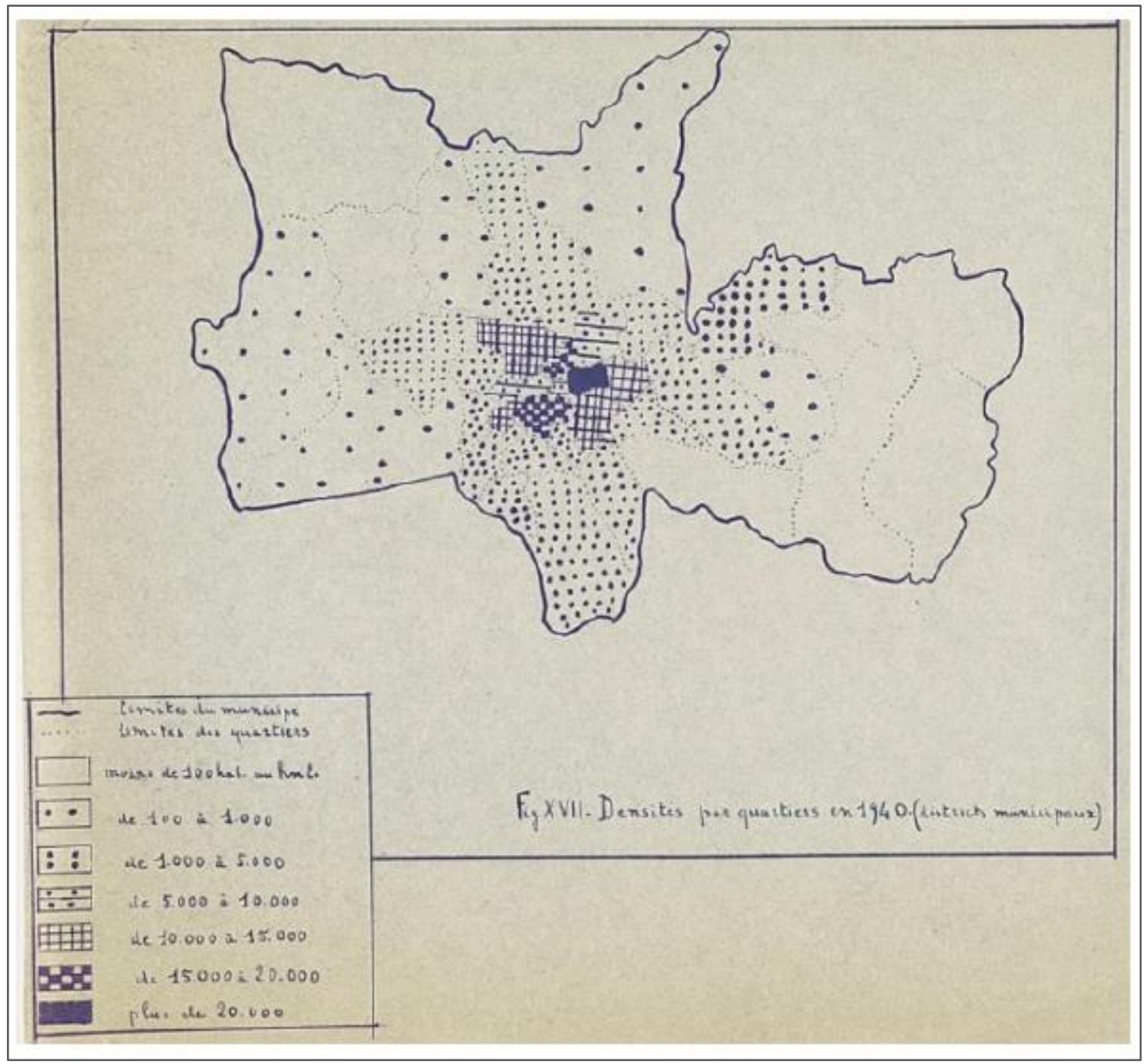

Fonte: Arquivo do IEB/USP, acervo Pierre Monbeig

$\mathrm{Na}$ tentativa de mais uma vez disciplinar e tornar as transições imobiliárias seguras, em 1937 é editado o Decreto-Lei no. 58 de 1937. Essa norma surgiu da necessidade de regulação da atividade comercial de parcelamento do solo, e foi a primeira lei nacional a fazer isso nos âmbitos territoriais urbano e rural. Seu principal objetivo era a regulamentação da venda de terrenos a prazo, conforme visto. Antes do Decreto-lei nํ. 58, o compromisso de compra e venda de imóveis conferia aos adquirentes apenas direitos obrigacionais. Findos os pagamentos das parcelas, extinta a obrigação, se o imóvel não fosse entregue ao adquirente, apenas lhe restaria a via indenizatória.

Contudo, é importante salientar que, muito embora o Decreto-Lei no. 58 de 1937 se pretendesse regular o parcelamento do solo, a natureza dessa norma era 
eminentemente consumerista, posto que se tratava de conjunto de normas tendentes à proteção do adquirente de lotes que o fizesse a prazo. Assim, encontramos pouquíssimos dispositivos urbanísticos visando à regulação do solo ou ao planejamento urbano. A leitura atenta da motivação da norma, logo no início da mesma nos fornece essa dimensão:

O Presidente da República dos Estados Unidos do Brasil, usando da atribuição que Ihe confere o artigo 180 da Constituição:

Considerando o crescente desenvolvimento da loteação de terrenos para venda mediante o pagamento do preço em prestações;

Considerando que as transações assim realizadas não transferem o domínio ao comprador, uma vez que o art. 1.088 do Código Civil permite a qualquer das partes arrepender-se antes de assinada a escritura da compra e venda;

Considerando que êsse dispositivo deixa pràticamente sem amparo numerosos compradores de lotes, que têm assim por exclusiva garantia a seriedade, a boa fé e a solvabilidade das emprêsas vendedoras;

Considerando que, para segurança das transações realizadas mediante contrato de compromisso de compra e venda de lotes, cumpre acautelar o compromissário contra futuras alienações ou onerações dos lotes comprometidos;

Considerando ainda que a loteação e venda de terrenos urbanos e rurais se opera frequentemente sem que aos compradores seja possível a verificação dos títulos de propriedade dos vendedores. (Brasil, 1937).

Nesse aspecto destacam-se os apontamentos de Leonelli (2017) acerca da matéria, que corroboram para o sentido iminentemente consumerista e de raras inserções urbanísticas e para a não exigência de prévia implantação de infraestrutura no parcelamento, o que ocorreu apenas em diplomas legais algumas décadas posteriores, conforme mencionado abaixo:

Para estudo, destacam-se alguns trabalhos que definem uma periodização da regulação do parcelamento do solo no Brasil. Bonduki, (2007), em um breve histórico sobre a regulamentação do parcelamento do solo no Brasil, pontua três grandes momentos:

1 - Década de 30: momento em que a legislação tinha como objetivo garantir a segurança do lote à prestação. Trata-se do início da expansão urbana pelo padrão periférico, via proliferação de lotes. O combate à ilegalidade e 
qualidade urbanística não era o escopo da regulação desse período (o DF 48/1937 é a legislação vigente referente a esse assunto no país.

2 - Década de 70: o foco da legislação era o controle do loteamento clandestino e a garantia da qualidade urbanística com exigências de implantação de infraestrutura e doação de área públicas (aprovação da LF 6.766/79).

3 - Início século XXI - discussão atual sobre a revisão da LF 6766/79. A discussão está pautada na regularização dos parcelamentos e assentamentos legais e da necessidade de uma nova tipologia de condomínios fechados. (LEONELLI, 2017, p. 38).

Contudo, há um aspecto no Decreto-Lei 58 de 1937 que merece análise mais detida: as disposições acerca da destinação de áreas públicas no interior do parcelamento: "Art. 3ํ A inscrição torna inalienáveis, por qualquer título, as vias de comunicação e os espaços livres constantes do memorial e da planta." (Brasil, 1937). Este singelo dispositivo, embora imbuído do sentido protetivo das áreas de uso comum do povo nos planos de parcelamento do solo, foi alvo de inúmeras discussões sobre o real alcance teleológico ao longo das décadas seguintes. Isso por razão de sua dubiedade.

Como se pode inferir da leitura do Decreto no. 58 de 1937, não há qualquer dispositivo que exija a destinação de áreas públicas nos planos de loteamentos à título de vias públicas ou espaços livres. Contudo, de forma lacônica, foi inserido o art. 3ํㅡ, o que denota que provavelmente legislações municipais ou estaduais já deveriam prever tal exigência ${ }^{3}$.

Outro aspecto de extrema relevância que gerou efeitos fáticos e jurídicos na conformação das cidades se refere à titularidade de domínio das vias públicas e dos

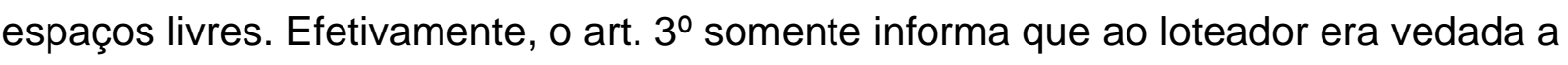

\footnotetext{
${ }^{3}$ O Código Arthur Saboya, Código de Obras do Município de São Paulo, editado em 19 de novembro de 1929, disciplina a destinação de área públicas em seu art. 518:

Art.733 - Quando o terreno a arruar tiver superfície igual ou superior a quarenta mil metros quadrados, o espaço ocupado por vias de comunicação (ruas, avenidas, etc) não poderá ser inferior a vinte por cento da superfície total do terreno. Deverá além disso, ser deixada para espaços livres (praças, jardins, squares, etc), de domínio público uma área correspondente, pelo menos, a: Cinco por cento da área total - na zona urbana; Sete por cento da área total - na zona suburbana; Dez por cento da área total - na zona rural.
} 
alienação dessas áreas, mas é silente sobre a indicação da propriedade das mesmas a partir do registro mediante inscrição do loteamento junto ao cartório de registro de imóveis. A regra de ouro do direito civil que infere que só é dono quem registra era o argumento de autoridade de loteadores que praticavam a diminuição ou a supressão total dos espaços livres durante o processo de implantação do loteamento. Alegavam que esses espaços livres jamais foram transferidos à municipalidade, posto que não foi transferida a titularidade de domínio dos mesmos. Essa questão foi amplamente tratada pela doutrina jurídica. Segundo Meirelles (1977):

Não há, nem pode haver vias e logradouros públicos como propriedade particular. Toda área de circulação ou de recreação pública é bem de uso comum do povo e, portanto, bem do domínio público por destinação, dispensando titulação formal para o reconhecimento de tal dominialidade. (MEIRELLES, 1977, p. 621).

Conforme Ferreira (1938), o proprietário, ao retalhar o imóvel, deixou os espaços destinados à circulação e ao uso comum. $E$ isso foi levado em conta na celebração dos contratos objetivando a alienação ou aquisição dos lotes. É fora de controvérsia, observa, que,

(...) tendo sido o plano de loteamento, em seu conjunto e nos seus pormenores, parte predominante na formação da vontade dos compradores de lotes, não deve ser essa situação modificada de tal forma que, se outra fosse, ou eles não teriam feito a compra ou somente a teriam realizado mediante o pagamento de menor preço. (FERREIRA, 1938, p. 116).

Outro aspecto ressaltado pelo autor é que, "declarando inalienáveis, por efeito do registro do memorial e da planta, as vias de comunicação e os espaços livres deles constantes, colocou-os a lei fora do comércio, com torná-los inegociáveis." Ainda sobre o tema esclareceu Miranda (1957):

Tem-se pretendido que as vias de comunicação e os espaços livres somente se tornem públicos por atos dos interessados entregando-os à Prefeitura Municipal. De modo nenhum. A aprovação do loteamento faz públicas as vias de comunicação e públicos os espaços livres, com a exigência de serem ultimadas pelos loteadores as obras das vias de comunicação e os espaços livres e da modificabilidade segundo o Dec-lei no 58. (MIRANDA, 1957, p. 89).

Em outro de seus estudos, o jurista afirma: 
(...) Tem-se pretendido que as vias de comunicação e os espaços somente se tornem públicos por atos dos interessados, entregando-os à Prefeitura Municipal. De modo nenhum. A aprovação do loteamento faz públicas as vias de comunicação e públicos os espaços livres. (MIRANDA, 1955, p. 57).

Ao longo das décadas, o entendimento de que, muito embora o loteador não tenha transferido o domínio à Municipalidade das áreas públicas, o poder público não se subsumi às regras de direito privado - e sim às de direito público - foi se consolidando. O mesmo ocorreu com a compreensão de que a destinação de áreas públicas pelo loteador foi parte do plano do loteamento e, portando, de destinação intrínseca ao ato. Essa posição doutrinária foi denominada concurso voluntário, instituto oriundo do direito francês offre de concurs e acolhido pelo direito administrativo como forma de aquisição da propriedade por parte da municipalidade, pela transferência do domínio das áreas destinadas às ruas e praças de determinado loteamento, sendo essa a solução conforme o melhor direito ${ }^{4}$.

À guisa de elucidação da celeuma acerca da destinação das áreas públicas oriundas de parcelamentos do solo, vale destacar um julgado do Supremo Tribunal Federal, de 1972. Esse julgado é assim ementado:

Desapropriação. Área loteada. Espaços livres. Praças e ruas. Aprovação do loteamento pela prefeitura. Efeitos. Direito de receber o preço de indenização das áreas reservadas ao domínio público. Verificado o concurso voluntario, com a aprovação do loteamento pelo poder público, inscrito, após, opera-se pleno juris. Face ao direito administrativo, o domínio áreas reservadas ao uso público. Aplicação do art. 3 do decreto-lei n. 58/37. Exegese firmada nos tribunais, inclusive na suprema corte. Recurso provido. (RE 73044, Relator(a): Min. THOMPSON FLORES, Segunda Turma, julgado em 28/04/1972, DJ 05-06-1972 PP-03536 EMENT VOL-00876-02 PP-00370 RTJ VOL-00062-03 PP-00465). (STJ, 1972, on-line).

Este caso é referente a um processo de desapropriação pelo Estado de São Paulo de uma área para fins de construção de uma escola. No curso da ação, apresentaram-se coproprietários interessados outros na área, figurando entre eles o

\footnotetext{
${ }^{4}$ Definição contida no julgado: TJ-PR - AC: 675330 PR Apelação Cível - 0067533-0, Relator: Sidney Mora, Data de Julgamento: 02/12/1998, 2ª Câmara Cível, Data de Publicação: 21/12/1998 DJ: 5292
} 
Município de São Paulo e a Sociedade Construtora Mont Kemel Ltda. O juízo de primeiro grau excluiu o município na pretensão deduzida, por falta de prova de seu domínio de parte da área compreendida no loteamento da sociedade citada. Houve recursos dos interessados, até que, por fim, o caso foi apreciado pelo STF. Em 1972, a decisão foi pelo provimento do Recurso Extraordinário do Município, concluindo que, efetivamente, a área pertencia ao Município de São Paulo, por força da teoria do concurso voluntário. Vejamos trecho transcrito do relatório do Ministro Thompson Flores:

Quando apelou da decisão de Primeira Instância, a municipalidade instruiu seu recurso com cópias do processo de aprovação do loteamento, formado com o pedido da sociedade loteadora, e da inscrição final do loteamento no registro de imóveis. Dentre os documentos está o memorial descritivo que servindo para a aprovação da planta, atribuindo ao loteamento a área total de 480.080 metros quadrados (fls. 519 e 542). Ora, esse memorial reserva expressamente $10 \%$ da área loteada para jardins, na extensão de 45.012,40 metros quadrados (fls. 519) e se reporta-se nos termos da lei à planta do loteamento, autuado a fls. 524, onde estão representados esses mesmos 45.012,40 metros quadrados de jardins - com indicação gráfica pela qual se verifica que uma parcela da área reservada para o uso público constitui parte da quadra 20 do loteamento atingida pela desapropriação, tal como sustenta a municipalidade na fundamentação do pedido. O memorial e a planta mencionados. foram aprovados pela municipalidade, que assim aceitou 0 plano neles apresentado e, automaticamente, assumiu o domínio das áreas reservadas para ruas e jardins. Ora, como é da doutrina pacífica e da jurisprudência uniforme, invocada pela recorrente, com a aprovação do loteamento pelo poder público, as áreas reservadas passaram para o domínio público, independentemente de transcrição imobiliária, e o certo é que, no caso, a inscrição do loteamento no registro de imóveis fez-se a desapropriação, só ocorreu mais tarde, em 1961. Evidente, portanto, data venia, que o acórdão desatendeu à regra do artigo $3^{\circ}$ do Decreto-lei ํo. 58, de contrariar a jurisprudência do colendo Supremo Tribunal Federal (particularmente o acórdão da R.T.J. 50/686, indicado a fls. 595), quando indeferiu a pretensão da municipalidade à indenização devida pela área de 2.704,70 m². (STJ, 1972, on-line).

Como se conclui do presente caso, a ação expropriatória se iniciou em 1961 e somente teve seu desfecho em 1972 - passados 11 anos da edição do decreto 
expropriatório e 35 anos do Decreto-lei 58, de 1937, quando finalmente houve o entendimento pela dominialidade do município da área pública em questão. Isto denota a insegurança jurídica vivida pela imprecisão dos dispositivos do Decreto-Lei no. 58 de 1937 acerca da matéria. Com o decorrer dos anos, a teoria do concurso voluntário veio se tornando majoritária em nossos tribunais, quando finalmente foi incorporada ao ordenamento jurídico junto ao Decreto-Lei no. 271 de 1967 e, posteriormente, pela Lei 6.766 de 1979, pacificando a questão para os parcelamentos implantados a partir de 1967. Contudo, o imbróglio jurídico para as áreas públicas ocupadas ou suprimidas anteriormente a essa data continuou.

Com o acelerado processo de urbanização do Brasil a partir da década de 50, por certo, as áreas públicas dos parcelamentos não foram poupadas da ocupação da massa empobrecida em busca de solo barato nas cidades. Daí que a questão da identificação da titularidade de domínio dos espaços livres é quesito essencial para os procedimentos de regularização fundiária, como veremos adiante. Tal questão, para fins de regularização fundiária, só foi equacionada com a edição da Lei no. 12.424, de 2011, que introduziu o art. 195-A na Lei nacional de Registros Públicos, Lei nº. 6.015, de 1973, claramente informando:

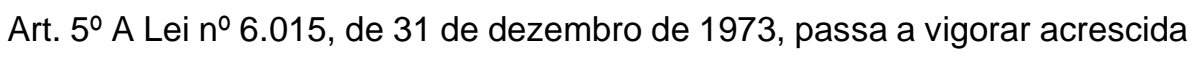
dos seguintes arts. 195-A e 195-B e do Capítulo XII do Título V, com os arts. 288-A, 288-B, 288-C, 288-D, 288-E, 288-F e 288-G: [...]

art. 195A, § 3‥ Não será exigido, para transferência de domínio, formalização da doação de áreas públicas pelo loteador nos casos de parcelamentos urbanos realizados na vigência do Decreto-Lei no 58 , de 10 de dezembro de 1937. (BRASIL, 2011, grifo nosso).

Assim, de 1937 a 2011, durante 74 anos, a ambiguidade da redação do Decreto-Lei no. 58 de 1937 gerou consequências devastadoras para os assentamentos informais que se formaram em áreas públicas e, também, para aqueles casos nos quais o loteamento foi inscrito e não foi implantado, sendo posteriormente ocupado ou implantado de forma distinta do plano registrado. Nesse último caso, a discussão jurídica era a seguinte: se seria possível, juridicamente, a desafetação das áreas públicas para fins de regularização fundiária. Decerto, tal questionamento levou décadas para ser equacionado, daí a importância de trazermos 
o tema. O Decreto-Lei 58, de 1937 foi regulamentado pelo Decreto №. 3.079 de 1938, na época sem trazer alterações significativas.

\section{DO DECRETO-LEI 271, DE 1967}

O Decreto-Lei no. 271, de 28 de fevereiro de 1967, que dispôs sobre "loteamento urbano, responsabilidade do loteador concessão de uso e espaço aéreo" (Brasil, 1967), efetivamente, foi a primeira norma que mais incisivamente regulou o território URBANO parcelado, antes mesmo da Lei Federal no․ 6766/79. A norma estabeleceu conceitos urbanísticos inéditos à época:

Figura 3 - Conceitos urbanísticos estabelecidos pelo Decreto-Lei nํ. 217 de 1967

Loteamento urbano - a subdivisão de área em lotes destinados à edificação de qualquer natureza que não se enquadre no disposto no $\S 2^{\circ}$ deste artigo (art. $1^{\circ}$. $\$ 1^{\circ}$ ).

Desmembramento - a subdivisão de área urbana em lotes para edificação na qual seja aproveitado o sistema viário oficial da cidade ou vila sem que se abram novas vias ou logradouros públicos e sem que se prolonguem ou se modifiquem os existentes. (art. 1ํ. $\S 2^{\circ}$ ).

Zona Urbana - a da edificação contínua das povoações, as partes adjacentes e as áreas que, a critério dos Municípios, possivelmente venham a ser ocupadas por edificações contínuas dentro dos seguintes 10 (dez) anos (art. $\left.1^{\circ} . \S 3^{\circ}\right)$.

Analogia: loteamentos e condomínios - aplica-se a Lei ํo 4.591, de 16 de dezembro de 1964, equiparando-se o loteador ao incorporador, os compradores de lote aos condôminos e as obras de infraestrutura à construção da edificação (art. $3^{\circ}$ ).

Como se pode observar, o Decreto-Lei no. 271 de 1967 tem uma feição muito próxima da Lei Federal 6766, de 1979, que será decretada somente 12 anos depois.

No que tange o tratamento jurídico das áreas públicas provenientes do parcelamento do solo urbano, o Decreto-Lei nํ. 271 resolveu a questão com seu art. $4^{\circ}$., dirimindo a polêmica questão da titularidade das áreas públicas, a qual motivou acalorados debates ao longo das décadas que antecederam à sua edição:

"Art 4ํㅡㄹ Desde a data da inscrição do loteamento passam a integrar o domínio público de Município as vias e praças e as áreas destinadas a edifícios 
públicos e outros equipamentos urbanos, constantes do projeto e do memorial descritivo." (Brasil, 1967).

Contudo, a grande contribuição da norma anteriormente citada para a regularização fundiária foi a criação do instituto da concessão do direito real de uso. A redação original do art. $7^{\circ}$. praticamente definiu a natureza jurídica do instituto, tornando-o apto a ser aplicado:

"Art 7ํ É instituída a concessão de uso de terrenos públicos ou particulares, remunerada ou gratuita, por tempo certo ou indeterminado, como direito real resolúvel, para fins específicos de urbanização, industrialização, edificação, cultivo da terra, ou outra utilização de interêsse social." (Brasil, 1967).

Posteriormente, o art. 7ํ. ganhou nova redação por meio da Lei n 11.481 de 2007, que dispôs sobre regularização de terras da União, assim definindo a redação atual do art. $7^{\circ}$.:

"Art. 7º. É instituída a concessão de uso de terrenos públicos ou particulares remunerada ou gratuita, por tempo certo ou indeterminado, como direito real resolúvel, para fins específicos de regularização fundiária de interesse social, urbanização, industrialização, edificação, cultivo da terra, aproveitamento sustentável das várzeas, preservação das comunidades tradicionais e seus meios de subsistência ou outras modalidades de interesse social em áreas urbanas." (Brasil, 2007).

Essa alteração possibilitou a utilização da concessão do direito real de uso para fins de regularização fundiária, voltada ao aproveitamento sustentável das várzeas, à preservação das comunidades tradicionais e seus meios de subsistência e a outras modalidades de interesse social em áreas urbanas. Desta forma, a ampliação do espectro de utilização do instrumento foi fundamental para o programa de regularização fundiária de terras na União, ou seja, voltada para os assentamentos urbanos de baixa renda. Os parágrafos do art. 7ํ.5 complementam as características da concessão do direito real de uso, que, sucintamente, são as seguintes:

${ }^{5}$ Redação do art. $7^{\circ}$ do Decreto-Lei 271 de 1967 dada pela Lei no 11.481 de 2007:

Art. $7^{\circ} \dot{E}$ instituída a concessão de uso de terrenos públicos ou particulares remunerada ou gratuita, por tempo certo ou indeterminado, como direito real resolúvel, para fins específicos de regularização fundiária de interesse social, urbanização, industrialização, edificação, cultivo da terra, aproveitamento 
Figura 4 - Características da concessão do direito real de uso

Forma: Instrumento público, ou particular, ou termo administrativo.

Registro: Inscrita ou cancelada em livro especial no Cartório de Registro de Imóveis.

Prerrogativas do titular: Poder de fruição, responde por encargos civis, administrativos e tributários que venham a incidir sobre o imóvel e suas rendas.

Rescisão: Se o titular der destinação diversa àquela do contrato.

Consequência da Rescisão: O titular perde as benfeitorias de qualquer natureza.

Transmissão: inter vivos ou causa mortis, salvo disposição em contrário.

Um dos municípios pioneiros a utilizar a concessão do direito real de uso foi Diadema, cidade pertencente à região metropolitana de São Paulo. Decerto, a cidade de Diadema carecia urgentemente de uma solução frente ao crescimento hiper acelerado da população, seguido da formação de favelas em seu território. Em 1960, o Município contava com população de 12.308 habitantes, sendo que, em 1980, esse número salta para 228.660 habitantes. Ou seja, a população de Diadema cresceu $1.758 \%$ em vinte anos. O número de favelas também aumentou: de 31, em 1970, para 128, em 1980 - aumento este de 313\% (BALTRUSIS, 2003).

sustentável das várzeas, preservação das comunidades tradicionais e seus meios de subsistência ou outras modalidades de interesse social em áreas urbanas.

$\S 1^{\circ}$ A concessão de uso poderá ser contratada, por instrumento público ou particular, ou por simples têrmo administrativo, e será inscrita e cancelada em livro especial.

$\S 2^{\circ}$ Desde a inscrição da concessão de uso, o concessionário fruirá plenamente do terreno para os fins estabelecidos no contrato e responderá por todos os encargos civis, administrativos e tributários que venham a incidir sôbre o imóvel e suas rendas.

$\S 3^{\circ}$ Resolve-se a concessão antes de seu têrmo, desde que o concessionário dê ao imóvel destinação diversa da estabelecida no contrato ou têrmo, ou descumpra cláusula resolutória do ajuste, perdendo, neste caso, as benfeitorias de qualquer natureza.

$\S 4^{\circ}$ A concessão de uso, salvo disposição contratual em contrário, transfere-se por ato inter vivos, ou por sucessão legítima ou testamentária, como os demais direitos reais sôbre coisas alheias, registrando-se a transferência. 
Figura 5 - Evolução da população de Diadema e \% da Taxa Geométrica de Crescimento Anual (IBGE)

\begin{tabular}{|c|c|c|c|c|}
\hline Ano & População & Domicílios & \multicolumn{2}{|c|}{ TGCA \% } \\
\hline 1960 & 12.308 & 2.490 & & \\
\hline 1970 & 78.914 & 15.468 & $1970 / 60$ & 20,42 \\
\hline 1980 & 228.660 & 52.364 & $1980 / 70$ & 11,23 \\
\hline 1991 & 305.000 & 82.055 & $1991 / 80$ & 2,66 \\
\hline 2000 & 357.064 & 83.775 & $1991 / 2000$ & 1,77 \\
\hline
\end{tabular}

Fonte: BALTRUSIS, Nelson. Instrumentos urbanísticos e o acesso à terra urbana em Diadema: o caso das AEIS. Ambiente construído, v. 3, no. 4, p. 5, 2003.

Figura 6 - Evolução das favelas e da população favelada

\begin{tabular}{|c|c|c|}
\hline Ano & N. $^{\circ}$ Núcleos & População \\
\hline 1968 & 02 & Sem informação \\
\hline 1970 & 31 & 12.271 \\
\hline 1980 & 128 & 79.271 \\
\hline 1995 & 197 & $95.000 *$ \\
\hline 2001 & 207 & $100.000 *$ \\
\hline
\end{tabular}

Fonte: BALTRUSIS, Nelson. Instrumentos urbanísticos e o acesso à terra urbana em Diadema: o caso das AEIS. Ambiente construído, $v$. 3, no. 4, p. 5, 2003.

Em 1988, foi editada a Lei municipal no. 975, que assim dispôs: "Desafeta áreas municipais e autoriza a outorga de concessões de direito real de uso independentemente de prévio procedimento licitatório à moradores de favelas e dá outras providências." (Brasil, 1988). Trinta e um assentamentos informais foram beneficiados por essa Lei Municipal, via outorga de forma gratuita de concessão de direito real de uso por 99 anos aos seus moradores. Tais territórios somam 130.000,00 $\mathrm{m}^{2}$. Efetivamente, a arrojada iniciativa, pouco antes da Constituição Federal de 1988, só foi possível pela pressão social, dos movimentos sociais da época, conforme esclarece Baltrusis:

O reconhecimento do direito à posse da terra dos favelados de Diadema remonta ao movimento de 84, quando os favelados tomaram a Câmara 
Municipal e pressionaram os vereadores a aprovar o instrumento de Concessão de Direito Real de Uso (CDRU), por 90 anos. A aprovação desse instrumento foi de grande importância para a luta do movimento dos favelados, não só para Diadema, mas para todo o país, inclusive para o movimento de reforma urbana. O reconhecimento do direito de posse, pela CDRU, tornou-se um marco histórico para a luta dos favelados contra a remoção, garantindo o direito da terra para quem nela mora. Para Alfonsin (1997), a concepção do programa de regularização fundiária no município é bastante abrangente, envolvendo um trabalho prévio de urbanização e melhorias no assentamento, imediatamente seguido de regularização jurídica. [...] a regularização jurídica só procede quando já tem pronta a recuperação urbana. De acordo com Mourad (2000, p. 66), "a discussão da Concessão do Direito Real de Uso - CDRU vinha sendo debatido pelo MDDF desde 1982. Em Diadema, a Associação dos Favelados de Diadema incorporou a proposta no $2^{\circ}$ Encontro de Favelas, realizado em junho de 1984. O Projeto de Lei de CDRU foi elaborado entre os técnicos da prefeitura e as lideranças dos movimentos de luta pelos direitos dos favelados de Diadema, com o objetivo de reconhecimento e legitimação do direito à terra para quem nela mora.

Para a aprovação, o movimento organizou uma enorme passeata no dia da votação do projeto de CDRU, o que pressionou os vereadores. Os arredores da Câmara Municipal foram tomados pelo movimento organizado, e o plenário, todo ocupado pela população, que exibia faixas e cartazes com o slogan. A terra é nossa. (BALTRUSIS, 2003, p. 06).

É imprescindível ainda mencionar uma característica fundamental em relação ao processo de regularização fundiária em Diadema nos anos 80: a titulação por meio da concessão do direito real de uso era atrelada tanto ao processo de planejamento urbano municipal, vez que as áreas eram gravadas como AEIS - Área de Especial Interesse Social, como também ao processo de urbanização (Baltrusis, 2003).

Contudo, deve ser lembrado que a experiência de Diadema não foi única. Os grandes centros urbanos desde 1970 viviam a experiência de expulsões e remoções violentas a nível nacional, criando assim uma esfera sócio legislativa para a geração de mecanismos que tendessem ao reconhecimento das áreas de exclusão territorial. Nesse sentido, a ausência de planos ou normas gerais de regularização fundiária, verteu para criação de soluções municipais. Conforme Fernandes: 
Em várias cidades como Belo Horizonte, Recife e Porto Alegre, dada a crescente mobilização social dos favelados clamando pelo reconhecimento de seus direitos e pela urbanização das favelas, as políticas públicas municipais evoluíram ao longo de várias décadas, no sentido de reconhecer, em alguma medida, o direito dos favelados a terem um lugar mais adequado no espaço da cidade. A partir da década de 1970, em vários municípios as expulsões violentas e remoções forçadas foram sendo gradualmente substituídas pela relativa tolerância dessas formas de ocupação ilegal, culminando com o reconhecimento oficial de algumas das áreas de favelas e dos direitos das comunidades que nelas vivem. De modo geral, o quadro jurídico em vigor naquele período - anterior à promulgação da Constituição Federal de 1988 - era adverso e não dava suporte pleno aos programas de regularização de favelas.

Os propositores dos programas tiveram de combinar diversos argumentos jurídicos e políticos para justificar as estratégias inovadoras adotadas para que os primeiros programas pudessem ser implementados. Em que pesem as importantes implicações sociais do fenômeno de invasão de terras urbanas, em termos estritos, até recentemente a questão dos direitos dos favelados era inequívoca: enquanto invasores, eles não tinham direitos, já que havia pouco suporte nos princípios jurídicos e legais existentes para uma justificativa de natureza socioeconômica ou política de um ataque tão radical aos direitos de propriedade. (FERNANDES, 2006, p. 38).

No bojo da demarcação de áreas de interesse social, Belo Horizonte e Recife tiveram papel de destaque como cidades pioneiras, as quais, já na década de 80 , se debruçaram no enfrentamento da questão da regularização fundiária de assentamentos informais urbanos. Em conclusão quanto a esse tópico, deve ser reconhecida, portanto, a contribuição do Decreto-Lei o․ 271 de 1967 como a primeira norma que categoriza efetivamente a atividade de parcelamento do solo como atividade pública, mesmo quando executada pela iniciativa privada, daí a exigência da chancela do Poder Público e o estabelecimento de requisitos materiais e formais em lei.

Além disso, do Decreto-Lei no. 271 cria o instituto de concessão do direito real de uso, que possibilitou experiências inéditas de regularização fundiária em algumas cidades, aliada à urbanização de favelas e à demarcação como território de especial interesse social. Tal instituto, longe de se tornar obsoleto, foi reformulado e previsto 
como instrumento da política pública pelo Estatuto da Cidade, Lei no. 10.257 de 2001, e regulado pela Medida Provisória no. 2220 de 2001. Ele também foi usado, inclusive, ao lado da Concessão de Uso Especial para fins de Moradia (CUEM) ao longo dos anos 2000, como um dos principais instrumentos de regularização fundiária de interesse social aplicável em áreas públicas urbanas ocupadas.

\section{DA LEI FEDERAL №. 6.766 DE 1979}

Também chamada de Lei Lehmann, a Lei nํ. 6.766 de 1979, no contexto de abertura política, surge em um momento de intensa urbanização, pelo qual o país passou a partir da década de 50 - com forte êxodo rural e oportunidades de empregos nos centros urbanos, mas, acima de tudo, calcado em um modelo de desenvolvimento econômico desigual em âmbito nacional e com pouca oferta de lotes formais. Reforçando a atividade de parcelamento do solo como atividade pública, a Lei nº. 6.766 de 1979 se esforça para abarcar as diversas faces da atividade de parcelamento do solo. Exemplo é a diversidade das matérias ali disciplinadas:

Figura 6 - Capítulos da Lei no. 6.766 de 1979

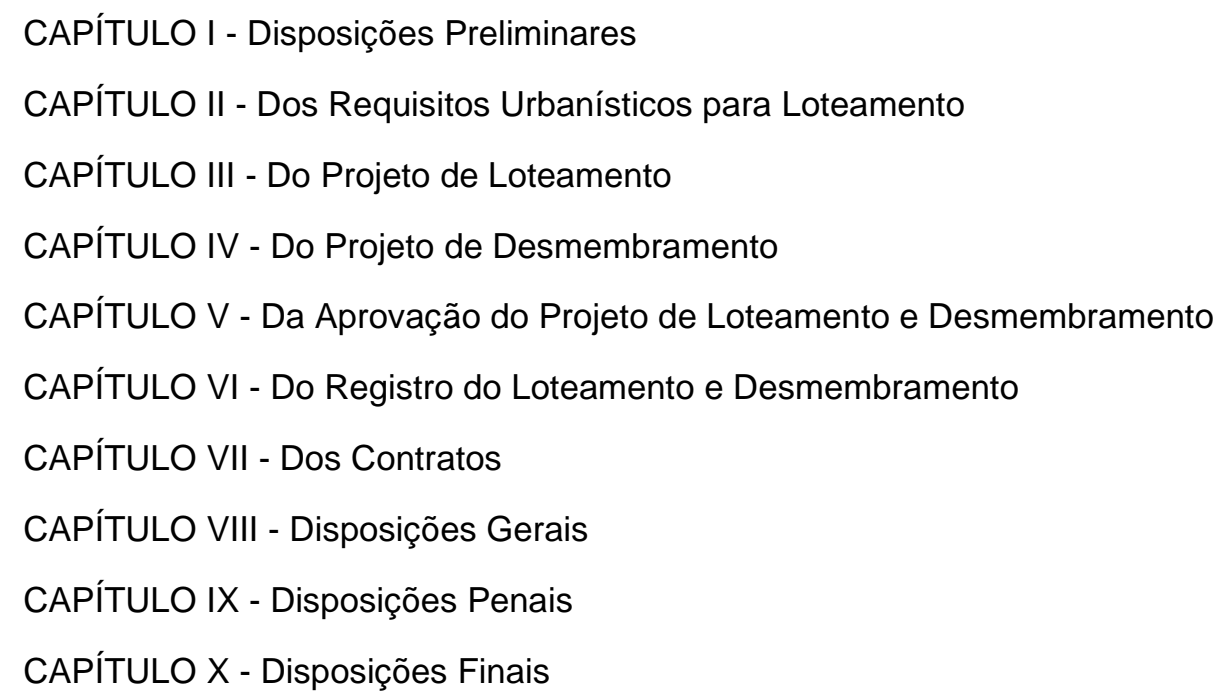

Como se nota, a Lei ㄲo. 6.766 de 1979 se apresenta quase como uma codificação da atividade de parcelamento do solo, disciplinando desde requisitos urbanísticos até projetos de parcelamento solo, de aprovação, de registro imobiliário, de contratos, de disposições criminais, e de intervenção do estado para garantir a 
regularização fundiária, mesmo que por meio de um viés consumerista, como veremos a seguir.

Seguindo a toada do Decreto-Lei nº. 58, de 1937, essa lei informa conceitos importantíssimos, padronizando a linguagem jurídica, tais como Gleba, Lote, Loteamento, Desmembramento:

Art. 2o. O parcelamento do solo urbano poderá ser feito mediante loteamento ou desmembramento, observadas as disposições desta Lei e as das legislações estaduais e municipais pertinentes.

$\S 10$ Considera-se loteamento a subdivisão de gleba em lotes destinados a edificação, com abertura de novas vias de circulação, de logradouros públicos ou prolongamento, modificação ou ampliação das vias existentes.

$\S 20$ Considera-se desmembramento a subdivisão de gleba em lotes destinados a edificação, com aproveitamento do sistema viário existente, desde que não implique na abertura de novas vias e logradouros públicos, nem no prolongamento, modificação ou ampliação dos já existentes. (...)

$\S 40$ Considera-se lote o terreno servido de infraestrutura básica cujas dimensões atendam aos índices urbanísticos definidos pelo plano diretor ou lei municipal para a zona em que se situe. (Brasil, 1979).

A Lei 6.766 de 1979 passa se ser um marco fundamental no trato da questão urbana, uma vez que determina, pela primeira vez na história, que os parcelamentos do solo devem ser antecedidos pela realização da infraestrutura mínima nela informada:

Art. $2^{\circ}$. (...) § 5‥ A infraestrutura básica dos parcelamentos é constituída pelos equipamentos urbanos de escoamento das águas pluviais, iluminação pública, esgotamento sanitário, abastecimento de água potável, energia elétrica pública e domiciliar e vias de circulação. (Brasil, 1979).

Além disso, ela timidamente descentraliza procedimentos, imputando a outros entes federativos competências específicas no trato do parcelamento do solo:

Art. 2․ O parcelamento do solo urbano poderá ser feito mediante loteamento ou desmembramento, observadas as disposicõos desta Lei $e$ as das legislacõos estaduais e municipais pertinentes. 
[...] $\S 4^{\circ}$ Considera-se lote o terreno servido de infraestrutura básica cujas dimensões atendam aos índices urbanísticos definidos pelo plano diretor ou lei municipal para a zona em que se situe.

Art. 6․ Antes da elaboração do projeto de loteamento, o interessado deverá solicitar à Prefeitura Municipal, ou ao Distrito Federal quando for o caso, que defina as diretrizes para o uso do solo, traçado dos lotes, do sistema viário, dos espaços livres e das áreas reservadas para equipamento urbano e comunitário (...).

Art. 7‥ A Prefeitura Municipal, ou o Distrito Federal quando for o caso, indicará, nas plantas apresentadas junto com o requerimento, de acordo com as diretrizes de planejamento estadual e municipal (...).

Art. 12. O projeto de loteamento e desmembramento deverá ser aprovado pela Prefeitura Municipal, ou pelo Distrito Federal quando for o caso, a quem compete também a fixação das diretrizes a que aludem os arts. $6^{\circ}$ e $7^{\circ}$ desta Lei, salvo a exceção prevista no artigo seguinte.

Art. 13. Aos Estados caberá disciplinar a aprovação pelos Municípios de loteamentos e desmembramentos nas seguintes condições:

I - quando localizados em áreas de interesse especial, tais como as de proteção aos mananciais ou ao patrimônio cultural, histórico, paisagístico e arqueológico, assim definidas por legislação estadual ou federal;

II - quando o loteamento ou desmembramento localizar-se em área limítrofe do município, ou que pertença a mais de um município, nas regiões metropolitanas ou em aglomerações urbanas, definidas em lei estadual ou federal;

III - quando o loteamento abranger área superior a $1.000 .000 \mathrm{~m}^{2}$.

Parágrafo único - No caso de loteamento ou desmembramento localizado em área de município integrante de região metropolitana, o exame e a anuência prévia à aprovação do projeto caberão à autoridade metropolitana.

Art. 14. Os Estados definirão, por decreto, as áreas de proteção especial, previstas no inciso I do artigo anterior.

Art. 15. Os Estados estabelecerão, por decreto, as normas a que deverão submeter-se os projetos de loteamento e desmembramento nas áreas previstas no art. 13, observadas as disposições desta Lei. 
Parágrafo único - Na regulamentação das normas previstas neste artigo, $\underline{0}$ Estado procurará atender às exigências urbanísticas do planejamento municipal. (Brasil, 1979, grifo nosso).

A lei também é responsável por muitos outros fatores notáveis, citados a seguir. Ela determina que o parcelamento do solo para fins urbanos seja realizado em zonas urbanas, de expansão urbana ou de urbanização específica, assim definidas pelo plano diretor ou aprovadas por lei municipal.

Art. 3․ Somente será admitido o parcelamento do solo para fins urbanos em zonas urbanas, de expansão urbana ou de urbanização específica, assim definidas pelo plano diretor ou aprovadas por lei municipal. (Brasil, 1979).

Ela veda o parcelamento do solo em terrenos alagadiços, aterrados com material nocivo à saúde, com declividade maior que 30\%, com condições geológicas inadequadas e em terreno de preservação ecológica.

Art. 3ํ. (...) Parágrafo único - Não será permitido o parcelamento do solo:

I - em terrenos alagadiços e sujeitos a inundações, antes de tomadas as providências para assegurar o escoamento das águas;

II - em terrenos que tenham sido aterrados com material nocivo à saúde pública, sem que sejam previamente saneados;

III - em terrenos com declividade igual ou superior a $30 \%$ (trinta por cento), salvo se atendidas exigências específicas das autoridades competentes;

IV - em terrenos onde as condições geológicas não aconselham a edificação;

V - em áreas de preservação ecológica ou naquelas onde a poluição impeça condições sanitárias suportáveis, até a sua correção. (Brasil, 1979).

Ela prevê a tipificação da atividade de parcelamento do solo quando não atendido os requisitos na lei, criminalizando essa conduta (art. 50 a 52). Além de todos esses principais aspectos, ela cria o Registro Especial, disciplinando o processo de registro do parcelamento do solo junto ao Cartório de Registro de Imóveis (art. 18 a 24), e também disciplina a formulação dos contratos do loteador com o adquirente, de modo a conferir segurança jurídica ao negócio (art. 25 a 36).

Porém, para a regularização fundiária, os principais dispositivos são aqueles que reconhecem a possibilidade de atividade irregular de parcelamento do solo, e estabelecem os procedimentos de intervenção do município, a fim de garantir os 
padrões urbanísticos e de segurança ao adquirente. Denominou-se essa modalidade de regularização fundiária ex officio, posto que a municipalidade passa a ser competente para, após notificado o loteador desidioso, efetuar todos os atos que caberia a este, tais como elaborar projetos, submeter à aprovação, implantar as obras de infraestrutura faltantes e registrar o parcelamento. Concomitantemente, o valor das prestações seria depositado pelo Cartório de Registro de Imóveis em uma conta judicial e sacado pelo Município após a realização de cada etapa do procedimento. (art. 37 a 49).

Deve ser registrada a ausência histórica de diálogo entre a legislação de parcelamento do solo e a legislação ambiental, que foi acirrada aos longos das décadas de 80 e 90 com a intensificação das atividades de parcelamento do solo urbano, precipuamente irregulares. A Lei nº 6.766 de 1979, por exemplo, determina faixa non aedificandi de 15 metros, ao passo que o Código Florestal que vigorou até 2012 - a Lei Federal no. 4.771 de 15 de setembro de 1965 - determinava a faixa mínima de 30 metros como área de preservação permanente (art. $2^{\circ}$., letra a, item 1). Salienta-se que as faixas mínimas de preservação permanente foram introduzidas no Código Florestal de 1965 pela Lei no 7.511, de 7 de julho de 1986, que vedava qualquer espécie de intervenção como, por exemplo, a regularização fundiária.

A vedação radical a qualquer tipo de construção em áreas ambientalmente protegidas foi um dos principais fundamentos de suporte às inúmeras ações de "desfazimento de loteamentos" intentadas pelo Ministério Público, sem oferta de qualquer solução habitacional à população de baixa renda. A posição jurisdicional era unânime no sentido de demolição, inclusive da doutrina jurídica à época:

"Outros efeitos de um loteamento irregular, sem condições de ser regularizado (loteamento feito em cima de mangue ou em área preservada, etc...) é o da Administração Pública poder embargar não só loteamento como qualquer obra construída em cima do referido loteamento mesmo que essas obras tenham obtido alvará de licença, esse alvará foi obtido a partir de um loteamento irregular no mais alto arrepio, daí não gerar direito adquirido, pois não existe direito adquirido em cima de qualquer ato ilícito". (BUCCI, 1998, p. 14, grifo nosso).

"O ato ilegal do particular que constrói sem licença rende ensejo a que a Administração use do poder de polícia que lhe é reconhecido para embargar, 
imediata e sumariamente, o prosseguimento da obra, e efetivar a demolição do que estiver irregular com seus próprios meios sem a necessidade de um procedimento formal anterior, porque não há licença ou alvará a ser invalidado. Basta a constatação da clandestinidade da construção, pelo auto de infração, para o imediato embargo e a ordem de demolição". (MEIRELLES, 1996, p. 185).

Conforme se pode concluir, os assentamentos informais urbanos, até o final da década de 90, eram tratados pela doutrina, pela jurisprudência e pelo poder judiciário como ato ilícito - por vezes contra o meio ambiente, por vezes em desfavor da administração pública - e, portanto, estavam sujeitos a penalidades demolitórias. A perspectiva era que a coibição administrativa ou judiciária dos assentamos informais desestimularia a formação de novos parcelamentos populares, desconsiderando os componentes do déficit de moradia formal e a impossibilidade de a população de baixa renda adquirir um lote regular.

A par dessa posição quase majoritária de ausência de reconhecimento da cidade informal, o Município de São Paulo rapidamente se estruturou para fazer frente aos desafios de uma cidade acentuadamente urbana e com um passivo de enorme gama de irregularidade fundiária.

\subsection{MUNICÍPIO DE SÃO PAULO COM O ADVENTO DA LEI FEDERAL №. 6.766 DE 1979}

O primeiro plano diretor de São Paulo, instituído por meio da Lei Municipal no․ 7.688 de 30 de dezembro de 1971, e o primeiro zoneamento da cidade como um todo, advindo da Lei Municipal nº 7.805 de 1ํ․ de novembro de 1972, se constituíram como normas estruturantes à regularização do passivo instalado, garantindo direito a usos e atividades não conformes que comprovassem anterioridade àquela data.

Em 1979 foi criada a Supervisão Especial de Regularização de Loteamentos e Arruamentos (SERLA) a fim de liquidar a demanda de regularização fundiária acumulada até então em caráter ex officio, isto é, promovida pelo Poder Público. Enquanto eram procurados e julgados criminalmente os loteadores, sem o êxito esperado, o ônus dos investimentos urbanísticos acabou sendo socializado com todos os contribuintes. Contudo, as esperanças eram depositadas nos novos dispositivos 
da Lei no. 6.766 de 1979, que permitia a intervenção dos municípios de forma ativa, admitindo a regularização fundiária dos mesmos:

Com a promulgação da Lei $6.766 / 79$, as prefeituras se viram munidas do instrumental legislativo necessário e adequado, que, havendo irregularidade nos loteamentos, elas assumissem a posição ativa de promover a regularização. Os dispositivos legais que constituem esse equipamento são os artigos 38, incisos segundo e quinto, 40 e 41, da mencionada lei. Evidentemente, haverá várias formas de utilização desses dispositivos, ao sabor das várias municipalidades e de acordo com as peculiaridades locais (VALENTE, 2003, p. 10).

Entretanto, um dos principais empecilhos encontrados pelos municípios para a execução de um programa em escala de regularização fundiária se encontrava na própria Lei №. 6.766 de 1979, a mesma que havia conferido competência aos municípios para proceder à regularização ex officio. A Lei Federal n‥ 6.766, ao estabelecer certos requisitos urbanísticos e a modalidade de Registro Especial, tinha em mira loteamentos novos, planejados - e não ocupações ou loteamentos irregulares, muitas vezes implantados por grileiros - em total desacordo com as posturas municipais e, no mais das vezes, sem a reserva de área pública, que, até 1999, era de 30\% da área loteada. O maior empecilho que logo se apresentou foi decorrente da exigência de apresentação de certidões negativas de débitos e outros documentos, previstos no art. 18 da Lei Federal nำ6.766, que inviabilizariam o prévio registro de parcelamentos parcelados junto à Serventia competente:

Há, pois, que examinar o que se deve entender como regularização do loteamento pela municipalidade. Deixado que foi para a municipalidade, fazer a exigência da execução pelo loteador, de obras, que no mínimo compreendam a abertura das vias de circulação, a demarcação dos lotes e a execução de galerias para escoamento de águas pluviais (art.18, inc. V, Lei 6.766/79), cumpre saber se nessa regularização está ou não a municipalidade obrigada a depositar em cartório o pedido de registro do loteamento, com todos os documentos a que alude o artigo 18 citado, cumprindo-se todo o processo, inclusive com a publicação de editais.

A resposta, evidentemente, há de ser negativa, considerando o fim social objetivado e que essa regularização, pela prefeitura municipal, é forma anômala de fazer o loteamento ingressar no registro imobiliário. 
Não se há que exigir, portanto, do poder público, que comprove a inexistência de ações contra o loteador ou a inocorrência de protesto de títulos de sua responsabilidade, ou que faça o memorial descritivo, ou que demonstre não haver débitos fiscais que, onerando a gleba, possa prejudicar os compradores, nem que apresente o modelo do contrato-padrão.

A dispensa desse procedimento é consequência de um fato simples: o loteamento irregular já foi executado e os lotes compromissados, de tal forma que não se busca prevenir futuros prejuízos, mas reparar faltas antes cometidas.

Por consequência, basta que a prefeitura requeira, com fundamento no artigo 41 da Lei 6.766/79, o registro do loteamento, e este, uma vez comprovada a propriedade do loteador sobre a gleba, matriculada esta, deverá ser registrado pelo cartório, sem a apresentação dos documentos referidos no artigo 18 da lei citada em publicação dos editais.

O título, para fins dos artigos 167, inciso I, no 19, e 221, inciso II, da Lei de Registros Públicos, é o requerimento da prefeitura municipal. O cartório fará um único registro, consignando que é feito a requerimento da prefeitura municipal e com esteio no artigo 41 citado, abrindo, em seguida, ficha auxiliar para controle dos registros dos compromissos e dos títulos de transmissão definitiva dos lotes, a exemplo do que faz quando o loteamento é registrado a pedido do loteador. (VALENTE, 2003, p. 12).

Assim, era dispensada a apresentação de documentos e certidões, sendo que os mesmos eram expressamente requeridos no texto da lei de parcelamento do solo. A solução foi a edição de Provimentos, que na época eram da lavra da Vara Corregedora dos Cartórios da Comarca de São Paulo e que, posteriormente, emprestaram seu texto às normas da Corregedoria Geral de Justiça do Estado de São Paulo. Portanto, a "adequação" da Lei №. 6.766/79 aos casos concretos de regularização fundiária era feita por meio de Provimentos do Tribunal de Justiça. Vejamos:

Provimento da $1^{\text {a }}$ Vara RP/SP disciplina registro de loteamentos e desmembramentos regularizados pela Prefeitura - Provimento no 02/82

O doutor José de Mello Junqueira, Juiz de Direito da 1a. Vara de Registros Públicos da Comarca da Capital e Corregedor-Permanente dos Cartórios de Registro de Imóveis da Capital, no uso das atribuições que Ihe são conferidas por lei, 
Considerando o que dispõem os artigos 40 e 41 da Lei nํ. 6.766, de 19 de dezembro de 1979;

Considerando o que ficou decidido no Processo 338/81;

Considerando a necessidade de disciplinar o registro de loteamento e desmembramentos regularizados pela Prefeitura Municipal de São Paulo; Considerando a necessidade de fixar a documentação que deve ser exigida pelos Cartórios para o registro desses loteamentos e desmembramentos;

Determina:

Artigo $1^{\circ}$ - Não se aplica o disposto no artigo $18 \mathrm{~d}$ a Lei 6.766, de 19 de dezembro de 1979, aos registros de loteamentos ou desmembramentos requeridos pela Prefeitura Municipal de São Paulo, com base no artigo 40 da mesma lei.

Artigo $2^{\circ}$ - O loteamento ou desmembramento deverá ser submetido ao Cartório de Registro de Imóveis, nos casos a que se refere o artigo anterior, por requerimento da Prefeitura Municipal de São Paulo, acompanhado dos seguintes documentos:

I - Planta do loteamento ou desmembramento contendo as subdivisões das quadras, as dimensões e numeração dos lotes, logradouros, espaços livres e outras áreas com destinação específica.

- Quadro indicativo das áreas ocupadas pelos lotes, logradouros e espaços livres e outras áreas com destinação específica.

- Certidão de propriedade com alienações e ônus nos casos em que o imóvel tenha passado para outra Circunscrição Imobiliária.

Artigo $3^{\circ}-$ A escrituração do registro a que se refere este Provimento obedecerá às normas da Lei 6.766, de 19 de dezembro de 1979, e Provimento desta Vara, dispensada a publicação de editais a que se refere 0 artigo 19 da referida lei.

Artigo $4^{\circ}$ - Nos loteamentos ou desmembramentos regularizados pela Prefeitura Municipal valerá como título hábil para a transmissão da propriedade dos lotes o contrato de compromisso de venda e compra devidamente firmado antes daquela regularização, desde que o adquirente comprove o pagamento ou depósito de todas as prestações do preço avençado e pagamento dos tributos devidos inter vivos. 
Parágrafo único - Terá a mesma validade o contrato de cessão de compromisso de venda e compra desde que firmado em instrumento apartado, estiver acompanhado do instrumento de compromisso de compra e venda. Nesta hipótese, serão ambos registrados.

Artigo $5^{\circ}$ - A comprovação do pagamento de todas as prestações a que alude o artigo anterior deverá ser feita perante o próprio Oficial do Cartório do Registro de Imóveis.

Artigo 6 - O Oficial, após examinar a documentação, achando-a conforme, procederá ao registro da transmissão da propriedade, arquivando uma via do título e comprovantes do pagamento.

Parágrafo único - Se a documentação for microfilmada poderá ser devolvida. Artigo $7^{\circ}$. - Este Provimento entrará em vigor na data de sua publicação.

Dado e passado nesta Comarca de São Paulo, a 3 de março de 1982.

Cumpra-se

Encaminhe-se cópia à Corregedoria Geral da Justiça.

José de Mello Junqueira

Juiz de Direito e Titular da 1a Vara de Registros Públicos"

Da mesma forma o Provimento ํ‥ 03/82:

Provimento da $1^{\text {a }}$ Vara RP/SP determina que não se aplica o art. 18 da Lei $6.766 / 79$ aos registros de loteamentos e desmembramentos requeridos pela Prefeitura - Provimento n‥ 3/82

O doutor José de Mello Junqueira, Juiz de Direito da 1a Vara de Registros Públicos e Corregedor-Permanente dos Cartórios de Registro de Imóveis da Capital, no uso das atribuições que Ihe são conferidas por lei,

Considerando as dificuldades ocorridas na regularização dos loteamentos pela Prefeitura Municipal de São Paulo;

Considerando os problemas sociais que possam acarretar a aplicação rígida do Provimento no 02/82 desta Vara,

Determina:

Artigo $1^{\circ}$ - Não se aplica o disposto no artigo $18 \mathrm{~d}$ a Lei 6.766, de 19 de dezembro de 1979, aos registros de loteamentos e desmembramentos requeridos pela Prefeitura Municipal de São Paulo, com base no artigo 40 da mesma lei. 
Artigo $2^{\circ}$ - O loteamento ou desmembramento deverá ser submetido ao Cartório de Registro de Imóveis, nos casos a que se refere o artigo anterior, por requerimento da Prefeitura Municipal de São Paulo, acompanhado dos seguintes documentos:

I - Planta do loteamento ou desmembramento contendo as subdivisões das quadras, as dimensões e numeração dos lotes, logradouros, espaços livres e outras áreas com destinação específica.

- Quadro indicativo das áreas ocupadas pelos lotes, logradouros e espaços livres e outras áreas com destinação específica.

- Certidão de propriedade com alienações e ônus nos casos em que o imóvel tenha passado para outra Circunscrição Imobiliária.

Artigo $3^{\circ}$ - A escrituração do registro a que se refere este Provimento obedecerá às normas da Lei 6.766, de 19 de dezembro de 1979, e Provimentos desta Vara, dispensada a publicação de editais a que se refere o artigo 19 da referida lei.

Artigo $4^{\circ}$ - $\mathrm{Na}$ impossibilidade de se proceder ao registro, o Cartório promoverá a averbação de abertura dos logradouros e outras áreas de destinação específica, passando a controlar a disponibilidade pelos registros efetuados, servindo a planta (artigo $2^{\circ}$, item I) como roteiro e aprovação do desmembramento das áreas.

Artigo 5o - Nos loteamentos ou desmembramentos regularizados pela Prefeitura Municipal, por registro ou averbação, valerá como título hábil para a transmissão da propriedade dos lotes o contrato de compromisso de venda e compra devidamente firmado antes daquela regularização, desde que o adquirente comprove o pagamento ou depósito de todas as prestações do preço avençado e pagamento dos tributos devidos inter vivos.

Parágrafo único - Terá a mesma validade o contrato de cessão de compromisso de venda e compra desde que firmado no próprio instrumento de compromisso de compra e venda ou, embora firmado em instrumento apartado, estiver acompanhado do instrumento de compromisso de compra e venda. Nesta hipótese, serão ambos registrados.

Artigo 60 - A comprovação do pagamento de todas as prestações a que alude o artigo anterior deverá ser feita perante o próprio Oficial do Cartório de Registro de Imóveis. 
Artigo $7^{\circ}$ - O Oficial, após examinar a documentação, achando-a conforme, procederá ao registro da transmissão da propriedade, arquivando uma via do título e comprovante do pagamento.

Parágrafo único - Se a documentação for microfilmada a poderá ser devolvida.

Artigo 8ㅇ - Regularizado o loteamento poderá o Cartório efetuar registros de novas alienações e de compromissos de compra e venda.

Artigo 9ำ - Este Provimento entrará em vigor na data de sua publicação.

Artigo $10^{\circ}$ - Ficam revogadas as disposições em contrário e o Provimento no $02 / 82$.

Dado e passado nesta Comarca de São Paulo, a 2 de j unho de 1982.

Cumpra-se.

Encaminhe-se cópia à E. Corregedoria-Geral da Justiça.

José de Mello Junqueira - Juiz de Direito

Prefeitura do Município de São Paulo (Brasil, 1982).

Como se pode deduzir, já em 1982 a experiência de regularização de loteamentos implantados à margem da lei já demonstrava que a Lei Federal ㄲo. 6.766 de 1979 não se adequava às necessidades dos procedimentos de regularização fundiária, carecendo, assim, de flexibilização da legislação federal. Isso revela a importância da edição dos Provimentos acima para conformar a norma federal aos casos concretos e para flexibilizar os imperativos da norma.

Mas não foi apenas o aspecto acima abordado que foi solucionado pelas normas editadas pelo juízo corregedor dos Cartórios da Comarca de São Paulo. Havia uma questão premente que clamava por uma solução rápida, ágil e de caráter protetivo aos adquirentes de lotes: o tratamento jurídico a ser adotado nos casos em que os adquirentes, durante o processo de regularização fundiária, estavam pagando prestações ao loteador faltoso.

Os arts. 38 a 40 da Lei Federal 6.766 disciplinam, dentre outras matérias, a suspensão do pagamento das prestações pelos adquirentes, o depósito das mesmas e a possibilidade de a prefeitura vir a obter judicialmente o levantamento das prestações depositadas a título de ressarcimento pelas importâncias despendidas 
com equipamentos urbanos ou as expropriações necessárias para regularizar o loteamento ou desmembramento. Nesta esteira, disciplinaram os Provimentos os procedimentos necessários à consecução dos objetivos cominados nos dispositivos informados da Lei Federal no 6.766 de 1979. Destaquemos trechos de alguns deles:

Provimento $n^{\circ}$. 09/80

O doutor Narciso Orlandi Neto, Juiz de Direito em exercício na 1a Vara de Registros Públicos, usando das atribuições que lhe são conferidas por lei,

Considerando a impossibilidade material de ser feito tal depósito diretamente nos cartórios de registro de imóveis;

Considerando que a Prefeitura Municipal de São Paul o e a Caixa Econômica do Estado de São Paulo, em convênio, se propõem a fornecer meios materiais e humanos, assumindo essa prestação de serviço público;

Considerando que o pagamento das prestações em agências bancárias, através de carnê, facilitará o cumprimento do $§ 10 \mathrm{~d}$ o art. no 38 da Lei 6.766/79,

Determina:

Art. $1^{\circ}-\mathrm{O}$ depósito a que se refere o $\S 10$ do art. no 38 da Lei 6.766/79 será feito na Caixa Econômica do Estado de São Paul o, em uma das 29 agências relacionadas no anexo no 1 deste Provimento, à escolha do interessado, através de carnê individual, em seu no me expedido pela Secretaria da Habitação da Prefeitura Municipal de São Paulo.

Art. $2^{\circ}-$ O depósito previsto no artigo anterior só será possível quando o loteamento ou desmembramento não se achar regularmente registrado, ou quando não for regularmente executado pelo loteador.

$1^{\circ}$ - Em qualquer das duas hipóteses, o depósito será condicionado à apresentação de prova de que o loteador foi notificado por adquirente de lote, pela Prefeitura ou pelo Ministério Público. T al prova será dispensada se 0 interessado demonstrar que foi notificado pela Prefeitura para suspender o pagamento das prestações restantes.

2ํ - Em se tratando de loteamento ou desmembramento não registrado, o depósito dependerá da apresentação do contrato de compromisso de venda e compra, ou de cessão, e de prova de que o imóvel está transcrito ou registrado em nome do promitente-vendedor, ou de que o promitente-cedente tem seu título registrado 
Art. 3ำ - Antes de efetuar o primeiro depósito, deverá o interessado retirar, junto à Secretaria da Habitação da Prefeitura Municipal de São Paulo, o "carnet" de recolhimento, provando, para tanto, o preenchimento das condições mencionadas no art. $2^{\circ}$ e seus parágrafos.

Parágrafo único - De cada carnê de recolhimento constará obrigatoriamente: número da conta; agência escolhida para os depósitos; nome do compromissário-comprador; nome do cessionário, se houver; denominação do loteamento ou desmembramento; cartório da circunscrição a que pertence o imóvel; valor total do contrato, número de prestações devidas quando da emissão do carnê e valor de cada prestação, tudo de acordo com o modelo constante do anexo no 2 deste Provimento.

Art. $4^{\circ}$ - A conta aberta em nome do adquirente do lote quando da apresentação, pela primeira vez, do carnê na agência escolhida vencerá juros e correção monetária e só será movimentada com autorização do Juiz de

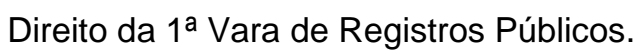

Art. 5o - O adquirente do lote, de posse do carnê, poderá fazer os pagamentos independentemente do pagamento de juros ou quaisquer acréscimos, mesmo que as prestações estejam atrasadas e ainda que não as atualize.

Art. $6^{\circ}$ - Ocorrendo o reconhecimento judicial da regularidade do loteamento antes do vencimento de todas as prestações, uma vez notificado pelo loteador através do cartório de registro de imóveis, o adquirente do lote passará a pagar as prestações diretamente àquele, retendo consigo o carnê como prova do pagamento das prestações depositadas.

Parágrafo único - O levantamento dos depósitos feitos dependerá do processo previsto no $\S 3^{\circ}$ do art. 38 da Lei 6.766/79.

Art. $7^{\text {o }}$ - O registro de propriedade previsto no art. 41 da Lei 6.766/79 dependerá da apresentação, no cartório competente, do contrato de compromisso, dos comprovantes dos pagamentos feitos diretamente ao promitente-vendedor ou promitente-cedente, do carnê com a autenticação mecânica de todas as demais prestações, e do comprovante de recolhimento do imposto de transmissão, sem prejuízo do cumprimento das outras exigências constantes da Lei de Registros Públicos.

Parágrafo único - O cartório de registro de imóveis só fará o registro previsto no caput ante a apresentação de certidão expedida pela Prefeitura de que 
conste que o loteamento foi por ela regularizado na forma prevista no art. 40 da Lei 6.766/79.

Art. 8 - Cada cartório de registro de imóveis terá um servidor apto a prestar as informações necessárias aos adquirentes de lotes, inclusive em relação à documentação necessária para obtenção do carnê.

Art. 9o - Tendo em vista que a Prefeitura dependerá sempre do prévio levantamento da situação de cada loteamento, os cartórios de registro de imóveis a ela fornecerão, independentemente de qualquer pagamento, as certidões que Ihe forem solicitadas para esse fim.

Art. $10^{\circ}$ - Este provimento entrará em vigor no dia 14 de dezembro de 1980, revogados os artigos 24 e 25 do Provimento 6/80 deste Juízo.

Cumpra-se, na forma e sob as penas da lei.

Dado e passado nesta cidade de São Paulo, aos 10 de dezembro de 1980. Narciso Orlandi Neto Juiz de Direito (Brasil, 1980).

Do mesmo modo previa o Provimento no $58 / 89$ da Corregedoria Geral de Justiça de São Paulo:

Nos loteamentos ou desmembramentos regularizados pelas Prefeituras Municipais, valerá, como título hábil a o registro dos lotes, o contrato de compromisso de venda e compra celebrado antes da regularização, desde que o adquirente comprove, perante o oficial, o pagamento ou o depósito de todas as prestações do preço avençado, bem como do imposto de transmissão devido, sem prejuízo do cumprimento de outras exigências previstas na Lei dos Registros Públicos. (Brasil, 1989).

As digressões acima sobre as normas extrajudiciais de regularização fundiária são importantes para entendermos que o grande problema social quanto à irregularidade fundiária que assolava a cidade era encontrar respaldo legal para o depósito das prestações dos lotes e para a operacionalização da regularização ex officio, a qual foi - e ainda é - fortemente impulsionada pela Prefeitura de São Paulo.

A partir da edição da Lei Federal №. 11.977 de 2009, outros Provimentos foram lançados pela Corregedoria Geral de Justiça do TJ/SP como, por exemplo, o Provimento no. 18/2012, o Provimento no. 21/2013 e o Provimento n‥ 37/2013. Com a edição da Lei №. 13.465/2017, foi editado o Provimento $n^{\circ}$. 51/2017 e, mais 
recentemente, foi editado o Provimento nº. 56/2019 da Corregedoria Geral de Justiça de SP com a atualização das Normas de Serviço para o extrajudicial, disciplinando a REURB de seu item 267 ao 448.

Em 1999, a Lei Federal nº. 6766 de 1979 foi objeto de um conjunto de alterações visando à adequação constitucional de seu texto, refletindo, outrossim, as tendências modernas de planejamento do solo urbano. De fato, a Lei nº 9.785 de 1999, essa ilustre desconhecida, não teve o prestígio que mereceu, pois introduziu notáveis dispositivos, especialmente no que concerne à regularização fundiária voltada à população de baixa renda. Ela promoveu alterações em algumas leis, a fim de possibilitar o registro de imissão provisória na posse para constituir título de domínio em nome do ente expropriante no início do processo de desapropriação. São exemplos destas leis: a Lei Nacional de Registros Públicos, Lei Federal nº 6.015 de 1973; a Lei de Desapropriação, Decreto-Lei no. 3.365 de 1941; e a própria Lei de Parcelamento do Solo Urbano, Lei nํ. 6.766, de 1979. O art. 5․ do Decreto-Lei no 3.365, modificado pela Lei no 6.602 de 7 de dezembro de 1978, passa a vigorar com as seguintes alterações:

Art. 5o (...) i) a abertura, conservação e melhoramento de vias ou logradouros públicos; a execução de planos de urbanização; o parcelamento do solo, com ou sem edificação, para sua melhor utilização econômica, higiênica ou estética; a construção ou ampliação de distritos industriais; (...)

§ 30 Ao imóvel desapropriado para implantação de parcelamento popular, destinado às classes de menor renda, não se dará outra utilização nem haverá retrocessão. (Brasil, 1999).

O inciso I do art. 167 da Lei no 6.015 de 1973, alterado pelas Leis $n^{\circ} 6.216$ de 1975 e $n^{\circ} 9.514$ de 1997, passa a vigorar acrescido do seguinte item 36:

Art. 167 (...) I - (...) 36) da imissão provisória na posse, e respectiva cessão e promessa de cessão, quando concedido à União, Estados, Distrito Federal, Municípios ou suas entidades delegadas, para a execução de parcelamento popular, com finalidade urbana, destinado às classes de menor renda. (Brasil, 1999).

A Lei no 6.766, de 19 de dezembro de 1979, passa a vigorar com as seguintes alterações: 
Art. 18 (...) $\S 4^{\circ} \mathrm{O}$ título de propriedade será dispensado quando se tratar de parcelamento popular, destinado às classes de menor renda, em imóvel declarado de utilidade pública, com processo de desapropriação judicial em curso e imissão provisória na posse, desde que promovido pela União, Estados, Distrito Federal, Municípios ou suas entidades delegadas, autorizadas por lei a implantar projetos de habitação. $\S 5^{\circ}$ No caso de que trata o $\S 40$, o pedido de registro do parcelamento, além dos documentos mencionados nos incisos V e VI deste artigo, será instruído com cópias autênticas da decisão que tenha concedido a imissão provisória na posse, do decreto de desapropriação, do comprovante de sua publicação na imprensa oficial e, quando formulado por entidades delegadas, da lei de criação e de seus atos constitutivos.

Art. 26. (...) $\S 3^{\circ}$ Admite-se, nos parcelamentos populares, a cessão da posse em que estiverem provisoriamente imitidas a União, Estados, Distrito Federal, Municípios e suas entidades delegadas, o que poderá ocorrer por instrumento particular, ao qual se atribui, para todos os fins de direito, caráter de escritura pública, não se aplicando a disposição do inciso II do art. 134 do Código Civil. $\S 4^{\circ}$ A cessão da posse referida no $\S 3^{\circ}$, cumpridas as obrigações do cessionário, constitui crédito contra o expropriante, de aceitação obrigatória em garantia de contratos de financiamentos habitacionais. $\S 5^{\circ} \mathrm{Com}$ o registro da sentença que, em processo de desapropriação, fixar o valor da indenização, a posse referida no $\S 3^{0}$ converter-se-á em propriedade e a sua cessão, em compromisso de compra e venda ou venda e compra, conforme haja obrigações a cumprir ou estejam elas cumpridas, circunstância que, demonstradas ao Registro de Imóveis, serão averbadas na matrícula relativa ao lote. $\S 6^{\circ}$ Os compromissos de compra e venda, as cessões e as promessas de cessão valerão como título para o registro da propriedade do lote adquirido, quando acompanhados da respectiva prova de quitação. (Brasil, 1999).

Essas alterações significativas acabaram por proporcionar o registro de inúmeras áreas em nome da Prefeitura de São Paulo no início dos anos 2000, cujas desapropriações tramitavam há décadas. Antes dessas alterações legislativas, o processo de regularização fundiária só podia ser iniciado quando o ente público adjudicava para si a área, ou seja, após décadas de tramitação processual, e com o pagamento integral do preço, finalizado com o pagamento dos precatórios. Essa pesquisadora teve a oportunidade de participar desse processo de registro de autos 
de imissão na posse de algumas áreas ocupadas, como, por exemplo, no Tiro ao Pombo, na Casa Blanca, em Miguel Ackel, na Vila Mara, no Jardim Paranapanema, no Conjunto Lidiane, no Casarão do Carmo, no Conjunto Cingapura Jardim dos Lagos, dentre outros.

Além das importantes alterações acima, a Lei no. 9.785 de 1999 introduziu o $§$ $6^{\circ}$. junto ao art. $3^{\circ}$. da lei $n^{\circ}$. 6.766/79, que, de certa forma, reconhece a peculiaridade dos territórios consistentes em assentamentos informais e passa a exigir infraestrutura mais econômica em áreas gravadas como ZHIS, o que certamente foi providencial para os programas de urbanização de favelas:

Art. $3^{\circ}$ (...) $\S 6^{\circ}$. A infraestrutura básica dos parcelamentos situados nas zonas habitacionais declaradas por lei como de interesse social (ZHIS) consistirá, no mínimo, de:

I - vias de circulação;

II - escoamento das águas pluviais;

III - rede para o abastecimento de água potável; e

IV - soluções para o esgotamento sanitário e para a energia elétrica domiciliar. (Brasil, 1999).

Sobre a lei em questão, são oportunas as lições de Lopes:

(...) Constatamos que as alterações introduzidas pela Lei no 9.785/99 na Lei no $6.766 / 79$, no tocante à flexibilização das normas quando o Estado promover empreendimentos imobiliários, tiveram como intuito minimizar a ausência, por longos anos, de investimentos em programas habitacionais. Isso em um quadro de profundas mudanças econômicas, que ocasiona o aumento de pessoas que não conseguem obter, mesmo com o trabalho, a garantia de habitação digna. O Estado, ao perceber que o modelo de acesso à terra no Brasil privilegia apenas determinadas classes sociais, o que não conseguiu atender a uma classe numerosa de miseráveis, promove alterações na legislação, instituindo um modelo dual de acesso a lotes: um para os pobres e outro para a classe média, já reproduzido em outros momentos da História. Uma legislação de parcelamento do solo que exclui determinadas classes sociais do acesso legal à terra causa grande impacto na produção dos espaços urbanos. A parcela da sociedade que não consegue obter habitação pelo modo tradicional de aquisição de lotes fica sujeita a outras formas de apropriação do espaço urbano. Dessa forma, são 
criados os espaços das favelas, dos cortiços, dos loteamentos clandestinos e irregulares e espaços mais privilegiados, como os loteamentos regulares, sem falar daqueles que não têm acesso a nenhuma dessas formas de moradia, vivendo em ruas, praças, marquises e viadutos. (LOPES, 2001, p. 94-95).

\section{DA CONSTITUIÇÃO FEDERAL DE 1988}

A Constituição Federal de 1988 representou uma mudança radical de paradigmas à atividade de reconhecimento dos assentamentos informais urbanos, mesmo que não tenha sido imediatamente após sua proclamação. Dentre os fundamentos da República está elencado a dignidade da pessoa humana e nos objetivos fundamentais temos a construção de uma sociedade livre, justa e solidária, com redução de desigualdade social. Estes são os fundamentos basilares que se constituem como fundamento de validade da regularização fundiária de assentamentos informais.

Tão fundamental quanto os princípios e objetivos acima é a introdução da relativização do exercício do direito real de propriedade, introduzido pela função social da propriedade no art. 5․ Inciso XXIII, junto ao Título II - Dos Direitos e Garantias Fundamentais e a seu Capítulo I - Dos Direitos e Deveres Individuais e Coletivos. A função social da propriedade urbana é cumprida quando atende às exigências fundamentais de ordenação da cidade expressas no plano diretor, nos termos do $\S 2^{\circ}$. do art. 182 da Constituição Federal. A função social da propriedade rural, enquanto isso, se dá com o aproveitamento racional e com a utilização adequada dos recursos naturais disponíveis e preservação do meio ambiente, segundo critérios e graus de exigência estabelecidos em lei, conforme determinado no art. 186 da Constituição Federal. A Constituição Federal (CF) previu ainda um sistema de repartição de competências entre os entes federais, administrativas e legislativas, inadmitindo, assim, qualquer espécie de hierarquia entre os entes, como se vislumbrou em legislações anteriores. Assim, a Constituição Cidadã, de forte cunho democrático e imbuída do espírito de fortalecimento e de descentralização dos entes federados, previu a sistemática de repartição de competências. 
Nessa toada, o critério preponderante adotado pela Constituição de 1988 é o do interesse. O princípio geral que norteia a repartição de competência entre as entidades do Estado federal é o da preponderância do interesse, segundo qual à União caberão aquelas matérias de predominante interesse geral, nacional; aos Estados os de interesse regional; e aos Municípios os de interesse local. Nisso, tendo a Constituição abandonado o conceito peculiar de interesse local, que em um século de existência nunca logrou uma conceituação satisfatória. Esse sistema busca realizar o equilíbrio federativo segundo uma técnica de repartição de competências, a qual se fundamenta na técnica da enumeração de poderes da União (arts. 21 e 22), com poderes remanescentes para os Estados (art. 25, $\S 1^{\circ}$ ) e poderes definidos indicativamente para os Municípios (art. 30).

A União dispõe de competência material ou administrativa exclusiva (art. 21 da $\mathrm{CF}$ ); de competência legislativa privativa (art. 22 da CF); de competência comum com os Estados, Distrito Federal e Municípios (art. 23 da CF); e de competência legislativa concorrente com os Estados (art. 24 da CF). A competência material ou administrativa refere-se ao exercício das funções governamentais, podendo ser tanto exclusiva da União, com a característica da indelegabilidade, quanto comum, que pode ser cumulativa, concorrente administrativa ou paralela. A Constituição de 1988 foi a primeira a tratar expressamente de Direito Urbanístico, atribuindo competência concorrente para a União, para os Estados e para o Distrito Federal, de modo a legislar sobre normas gerais nesse campo. Assim, considerando que os Municípios, por mandamento do art. 182, caput, devem executar a política de desenvolvimento urbano e ordenar o pleno desenvolvimento das funções sociais da cidade, é imperioso afirmar que aos Municípios foi conferida pela Constituição Federal ampla liberdade para tratar da matéria urbanística.

A União, no exercício de sua competência legislativa para dispor sobre normas gerais em matéria de direito urbanístico, editou as seguintes legislações: o Estatuto da Cidade, Lei Federal no. 10.257, de 2001; o Sistema Nacional de Habitação de Interesse Social (SHNIS) e o Fundo Nacional de Habitação de Interesse Social (FNHIS), criados por meio da Lei Federal no. 11.124, de 2005; a Política Nacional de Saneamento, Lei Federal no. LEI № 11.445 de 2007; o Programa Minha Casa Minha Vida (PMCMV), que foi um marco normativo da regularização fundiária participativa - 
instaurado pela Lei Federal no. 11.977 de 2009; a Política Nacional de Resíduos Sólidos, Lei Federal nº. 12.305 de 2010; a Política Nacional de Mobilidade, Lei Federal nº. 12.587 de 2012; o Estatuto da Metrópole, Lei Federal no. 13.089 de 2015; e a Regularização Fundiária e Alienação de Terras da União, Lei Federal nº 13.465 de 2017.

No que tange os Municípios, foi conferida ampla autonomia aos mesmos na Constituição Federal de 1988. Isso pode ser traduzido em autonomia de autogoverno, de administração própria e de legislação própria do âmbito de sua competência. $O$ Município passa a ser definido como pessoa jurídica de direito público interno, dotado de autonomia assegurada na capacidade de autogoverno e da administração própria. Assim, foram atribuídas as seguintes competências pela Constituição de 1988 aos Municípios: art. 30, I (competência municipal sobre assuntos de interesse local); art. 30, VIII (competência municipal sobre o adequado ordenamento territorial, mediante planejamento e controle do uso, do parcelamento e da ocupação do solo urbano); art. 182 (competência executiva em matéria urbanística atribuída ao poder público municipal, e competência normativa atribuída ao Plano Diretor); e art. 183 (requisitos e vedações para usucapião, como modo originário de aquisição do direito real de propriedade).

Um aspecto que se destaca no texto constitucional, por seu caráter expresso, se refere à competência executiva em matéria urbanística atribuída ao poder público municipal e à competência normativa atribuída exclusivamente ao Plano Diretor aprovado pela Câmara Municipal, nos termos do art. 182 da Constituição Federal. Conforme Silva:

(...) A Constituição de 1988 estruturou um sistema que combina
competências exclusivas, privativas e principiológicas com competências
comuns e concorrentes, buscando reconstruir o sistema federativo segundo
critérios de equilíbrio ditados pela experiência histórica. (SILVA, 2017, p.
481).

Tem-se, deste modo, que a política urbana constitucional confere um papel preponderante ao Município como ente federativo para atuar nos campos legislativo, administrativo e econômico, na promoção das políticas de desenvolvimento urbano, no planejamento e no ordenamento de uso e de ocupação de seu território (urbano e 
rural), e na promoção de políticas públicas que propiciam o pleno desenvolvimento das funções sociais da cidade e da propriedade e do bem-estar de seus habitantes . É ao Município que compete planejar e executar sua política de desenvolvimento urbano. Essa atribuição não retira responsabilidades e competências da União ou dos Estados, mas as delimita, até mesmo porque o ente federal e o estadual não seriam capazes de elaborar ou gerir o planejamento de cada um dos municípios brasileiros. À União e aos Estados não é dado conhecer as particularidades e interesses locais, os recursos disponíveis ou a concretude do território e de suas relações jurídicas. Também não estão aptos a perceber as consequências de certas determinações para o atendimento das necessidades e direitos dos habitantes de dada cidade. Neste cenário, cada ente federativo possui seu papel e nível de abrangência quando se trata da política urbana, de seus instrumentos e de sua interlocução com demais direitos, garantias e sistemas jurídicos. À União, por exemplo, cabe editar normas gerais de direito urbanístico e diretrizes para o desenvolvimento urbano, enquanto ao Município cabe promover adequado ordenamento territorial, mediante planejamento e controle do uso, do parcelamento e da ocupação do solo urbano.

Cabe destacar que, mesmo com a prevalência do interesse social, o planejamento urbano não pode nem deve coagir pessoas públicas ou privadas a determinado uso de seu imóvel ou mesmo a seu perdimento fora das hipóteses normativas constitucionais que regem a possibilidade de apropriação na forma da

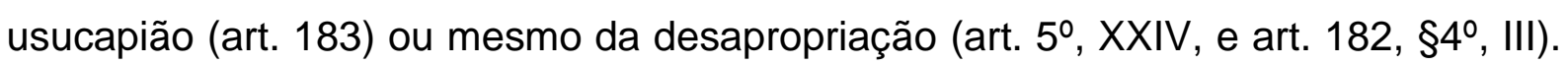
Deve haver, portanto, o equilíbrio entre os valores constitucionalmente postos.

Como visto, a política urbana constitucional possui como fundamentos: (1) a função social da propriedade (art. 5ำ XXIII; art. 170, III); (2) o planejamento urbano (art. 182, caput); (3) o bem-estar dos habitantes das cidades (art. 182, caput); (4) 0 direito à cidade (art. 182, caput); (5) o modelo de repartição de competências com papel predominante conferido ao Município (art. 24, I; art. 30, I e VIII; art. 182, caput); (6) a competência normativa do Plano Diretor (art. 182, §1ํ); (7) a vinculação da função social da propriedade urbana o atendimento das exigências do plano diretor (art. 182, $\S 2^{\circ}$ ); e (8) os limites impostos pelo direito de propriedade (art. 5ำ XXII e XXIV, art. 170, II; art. 182, §§ 3ํe 4ํㅜ ; art. 183). De modo geral, esse é o panorama do modelo de cidade escolhido e fixado pelo constituinte, assentado em novos critérios 
econômicos, sociais e ambientais, a ser respeitado e promovido pelas normas e políticas federais, estaduais e municipais que disserem respeito à urbanística.

Outro aspecto fundamental é o Direito Social à Moradia. O direito à moradia digna foi reconhecido e implantado como pressuposto para a dignidade da pessoa humana desde 1948, com a Declaração Universal dos Direitos Humanos, e foi recepcionado e propagado na Constituição Federal de 1988, por advento da Emenda Constitucional $n^{\circ} 26$, de 2000, em seu art. 6º, caput. Em razão do texto constitucional, o Estado Brasileiro (União, Estado, DF e Município) tem obrigação de: (a) definir metas e programas para a concretização ao Direito à Moradia, incluindo o planejamento urbano (cuja competência é do município); (b) adotar instrumentos financeiros, legais e administrativos para promover e efetivar uma política habitacional; e (c) garantir direito de acesso à justiça, para proteção à moradia. Conforme esclarece Saule Jr., a compreensão do alcance do conceito de moradia comporta componentes estruturais de observância obrigatória pelo Estado Brasileiro (União, Estado, DF e Município), originados de os comentários gerais da Comissão de Direitos Econômicos, Sociais e Culturais da ONU sobre o tema. Para que se promova moradia digna de maneira efetiva na sociedade é necessário observar seus componentes:

a. Segurança da posse: a moradia não é adequada se os seus ocupantes não têm um grau de segurança de posse que garanta a proteção legal contra despejos forçados, perseguição e outras ameaças.

b. Disponibilidade de serviços, materiais, instalações e infraestrutura: a moradia não é adequada se os seus ocupantes não têm água potável, saneamento básico, energia para cozinhar, aquecimento, iluminação, armazenamento de alimentos ou coleta de lixo.

c. Economicidade: a moradia não é adequada se o seu custo ameaça ou compromete o exercício de outros direitos humanos dos ocupantes, como, por exemplo, quando o aluguel é tão alto que acaba comprometendo mais de $30 \%$ do orçamento familiar.

d. Habitabilidade: a moradia não é adequada se não garante a segurança física e estrutural, proporcionando um espaço adequado, bem como a proteção contra frio, umidade, calor, chuva, vento, outras ameaças à saúde e, no limite, se gera risco à vida de seus moradores. 
e. Acessibilidade: a moradia não é adequada se as necessidades específicas dos grupos desfavorecidos, marginalizados e precarizados não são levados em conta.

f. Localização: a moradia não é adequada se for isolada de oportunidades de emprego, serviços de saúde, escolas, creches e outras instalações sociais, ou se localizada em áreas poluídas ou perigosas.

g. Adequação cultural: a moradia não é adequada se não respeitar e levar em conta a expressão da identidade cultural.

Assim, a Constituição Federal de 1988 é a norma mais importante que garante o fundamento de validade para todas as normas e ações atinentes à regularização fundiária pelos Municípios, e sua proclamação foi essencial para o suporte jurídico às legislações que sobrevieram. Contudo, até a edição do Estatuto da Cidade, não havia instrumentos infraconstitucionais ou norma geral que inovasse a ordem jurídica urbanística de modo a garantir a execução da política urbana de forma plena, tal qual conhecemos hoje. Uma excelente ilustração da "ginástica jurídica" que se fazia para lograr-se o mínimo de justiça urbana pode ser constatada por meio da decisão judicial abaixo, que data de 1995, da justiça federal da $8^{2}$. Vara de Belo Horizonte, que vale ser transcrita na íntegra:

Várias famílias (aproximadamente 300 - fls. 10) invadiram uma faixa de domínio ao lado da Rodovia BR 116, na altura do km 405,3, lá construindo barracos de plástico preto, alguns de adobe, e agora o DNER quer expulsálos do local. "Os réus são indigentes", reconhece a autarquia, que pede reintegração liminar na posse do imóvel. E aqui estou eu, com o destino de centenas de miseráveis nas mãos. São os excluídos, de que nos fala a Campanha da Fraternidade deste ano. Repito, isto não é ficção. É um processo. Não estou lendo Graciliano Ramos, José Lins do Rego ou José do Patrocínio. Os personagens existem de fato. E incomodam muita gente, embora deles nem se saiba direito o nome. É Valdico, José Maria, Gilmar, João Leite (João Leite ???). Só isso para identificá-los. Mais nada. Profissão, estado civil (CPC, artigo 282, II) para quê, se indigentes já é qualificação bastante? Ora, é muita inocência do DNER se pensa que eu vou desalojar este pessoal, com a ajuda da polícia, de seu moquiços, em nome de uma mal arrevesada segurança nas vias públicas. 
O autor esclarece que quer proteger a vida dos próprios invasores, sujeitos a atropelamento. Grande opção! Livra-os da morte sob as rodas de uma carreta e arroja-os para a morte sob o relento e as forças da natureza. Não seria pelo menos mais digno - e menos falaz - deixar que eles mesmos escolhessem a maneira de morrer, já que não Ihes foi dado optar pela forma de vida?

O Município foge à responsabilidade "por falta de recursos e meios de acomodações" (fls. 16 v). Daí, esta brilhante solução: aplicar a lei. Só que, quando a lei regula as ações possessórias, mandando defenestrar os invasores (artigos 920 e seguintes do CPC), ela - COMO TODA LEI - tem em mira o homem comum, o cidadão médio, que, no caso, tendo outras opções de vida e de moradia diante de si, prefere assenhorar-se do que não é dele, por esperteza, conveniência, ou qualquer outro motivo que mereça a censura da lei e, sobretudo, repugne a consciência e o sentido do justo que os seres da mesma espécie possuem. Mas este não é o caso no presente processo. Não estamos diante de pessoas comuns, que tivessem recebido do Poder Público razoáveis oportunidades de trabalho e de sobrevivência digna. Não. Os "invasores" (propositadamente entre aspas) definitivamente não são pessoas comuns, como não são milhares de outras que "habitam" as pontes viadutos e até redes de esgoto de nossas cidades. São párias da sociedade (hoje chamados excluídos, ontem de descamisados), resultado do perverso modelo econômico adotado pelo país. Contra este exército de excluídos, o Estado (aqui, através do DNER) não pode exigir a rigorosa aplicação da lei (no caso, reintegração de posse), enquanto ele próprio - o Estado - não se desincumbir, pelo menos razoavelmente, da tarefa que Ihe reservou a Lei Maior. Ou seja, enquanto não construir - ou pelo menos esboçar - "uma sociedade livre, justa e solidária“ (CF, artigo $\left.3^{\circ}, \mathrm{I}\right)$, erradicando "a pobreza e a marginalização" (n. III), promovendo "a dignidade da pessoa humana" (artigo $1^{\circ}$, III), assegurando "a todos existência digna, conforme os ditames da Justiça Social" (artigo 170), emprestando à propriedade sua "função social" (art. 5으, XXIII, e 170, III), dando à família, base da sociedade, "especial proteção" (art. 226), e colocando a criança e o adolescente "a salvo de toda forma de negligência, discriminação, exploração, violência, maldade e opressão" (art. 227), enquanto não fizer isso, elevando os marginalizados à condição de cidadãos comuns, pessoas normais, aptas a exercerem sua cidadania, o Estado não tem autoridade para deles exigir - diretamente ou pelo braço da Justiça - o reto cumprimento da lei.

Num dos braços a Justiça empunha a espada, é verdade, o que serviu de estímulo a que o Estado viesse hoje a pedir a reintegração. Só que, no outro, 
ela sustenta a balança, em que pesa o direito. $E$ as duas - lembrou RUDOLF VON IHERING há mais de 200 anos - hão de trabalhar em harmonia: "A espada sem a balança é força brutal; a balança sem a espada é a impotência do direito. Uma não pode avançar sem a outra, nem haverá ordem jurídica perfeita sem que a energia com que a justiça aplica a espada seja igual à habilidade com que maneja a balança"

Não é demais observar que o compromisso do Estado para com o cidadão funda-se em princípios, que têm matriz constitucional. Verdadeiros dogmas, de cuja fiel observância dependem a eficácia e a exigibilidade das leis menores.

Se assim é - vou repetir o raciocínio - enquanto o Estado não cumprir a sua parte (e não é por falta de tributos que deixará de fazê-lo), dando ao cidadão condições de cumprir a lei, feita para o homem comum, não pode de forma alguma exigir que ela seja observada, muito menos pelo homem "incomum". Mais do que deslealdade, trata-se de pretensão moral e juridicamente impossível, a conduzir - quando feita perante o Judiciário - ao indeferimento da inicial e extinção do processo, o que ora decreto nos moldes dos artigos 267, I e VI; 295, I, e parágrafo único, III, do Código de Processo Civil, atento à recomendação do artigo $5^{\circ}$ da LICCB e olhos postos no artigo 25 da Declaração Universal dos Direitos do Homem, que proclama:

"Todo ser humano tem direito a um nível de vida adequado, que lhe assegure, assim como à sua família, a saúde e o bem estar e, em especial, a alimentação, o vestuário e a moradia ".

Quanto ao risco de acidentes na área, parece-me oportuno que o DNER sinalize convenientemente a rodovia, nas imediações. Devendo ainda exercer um policiamento preventivo a fim de evitar novas "invasões". (PEREIRA, 1998, on-line).

\section{DO ESTATUTO DA CIDADE - LEI №. 10.257/01}

O Estatuto da Cidade vem regulamentar os arts. 182 e 183 da Constituição Federal de 1988. É a norma geral de política urbana. Ele estabelece diretrizes gerais para o desenvolvimento da política urbana, relaciona e disciplina os instrumentos a serem utilizados pelos Municípios para ordenar o pleno desenvolvimento das funções da cidade e da propriedade urbana (art. $2^{\circ}$ ). 
O Estatuto da Cidade tem como pressuposto a incumbência do Município, responsável pela execução da política urbana, de dispor de forma global e abrangente sobre o desenvolvimento urbano, de acordo com as particularidades do seu território, considerando o interesse local e tendo como base as normas gerais do Estatuto da Cidade.

A regularização fundiária permeia todo o Estatuto da Cidade. É uma de suas principais diretrizes. Nos termos do art. $2^{\circ}$. Inciso XIV, é indicado nominalmente como um instrumento e instituto jurídico político (art. $4^{\circ}$., Inc. V, "q"); como uma das causas motivadoras das utilização do direito de preempção (art. 26, Inc. I); como autorizador da transferência do direito de construir (art. 35, Inc. III); como de conteúdo obrigatório (ao menos as diretrizes) no plano diretor dos Municípios incluídos no cadastro nacional de municípios com áreas suscetíveis à ocorrência de deslizamentos de grande impacto, inundações bruscas ou processos geológicos ou hidrológicos correlato (art. 42-A, Inc. V); e como uma das condições para o estabelecimento de consórcio imobiliário (art. 46 caput e $\S 1^{\circ} \stackrel{\circ}{\circ}$.). Além disso, ele prevê dois instrumentos de regularização fundiária: a concessão de uso especial para fins de moradia e o conceito de concessão de direito real de uso (reformulado), previamente instituído pelo Decreto-Lei ํo. 271 de 1967.

Embora tenham sido os dois instrumentos acima previstos originalmente na redação do Estatuto da Cidade, estes foram vetados. Além disso, a Medida provisória no. 2.200/01 foi editada em setembro de 2001, estabelecendo regramento para a concessão de uso especial para fins de moradia e de forma parcimônia, para a concessão de direito real de uso, ambos de utilização em áreas públicas.

Contudo, apesar do status alcançado pela regularização fundiária junto ao Estatuto da Cidade, ainda faltava uma norma geral específica de regularização fundiária, vez que até então se utilizava subsidiariamente a Lei Federal №. 6.766 de 1979, que trata de parcelamento do solo para fins urbanos. Assim, desde a edição do Estatuto da Cidade em 2001 até a Lei 11.977 de 2009, os únicos instrumentos de regularização fundiária urbana que se poderia lançar mão eram a concessão de uso especial para fins de moradia e a concessão de direito real de uso para áreas públicas, e a usucapião em suas diversas modalidades para área privadas. 


\section{DO PROJETO DE LEI DE RESPONSABILIDADE TERRITORIAL URBANA E DO PROGRAMA PAPEL PASSADO DO MINISTÉRIO DAS CIDADES}

Em 2000, o então deputado federal Bispo Waderval apresentou o Projeto de Lei $n^{\circ}$. 3.057, que acabou por reunir cerca de 20 propostas apensadas tramitadas em conjunto. Quando uma proposta apresentada é semelhante a outra que já está tramitando, a Mesa da Câmara determina que a mais recente seja apensada à mais antiga. Se um dos projetos já tiver sido aprovado pelo Senado, este encabeça a lista, tendo prioridade.

O PL n․ 3.057 de 2000 pretendia apenas alterar o art. 41 da Lei Federal no. 6.766/79, cuja redação proposta evidencia um dos grandes entraves enfrentados pelos Municípios do Estado de São Paulo, que exigia a aprovação de os loteamentos junto ao GRAPROHAB.

Figura 8 - Íntegra do Projeto de Lei $\mathrm{n}^{\circ} .3 .057$ de 2000

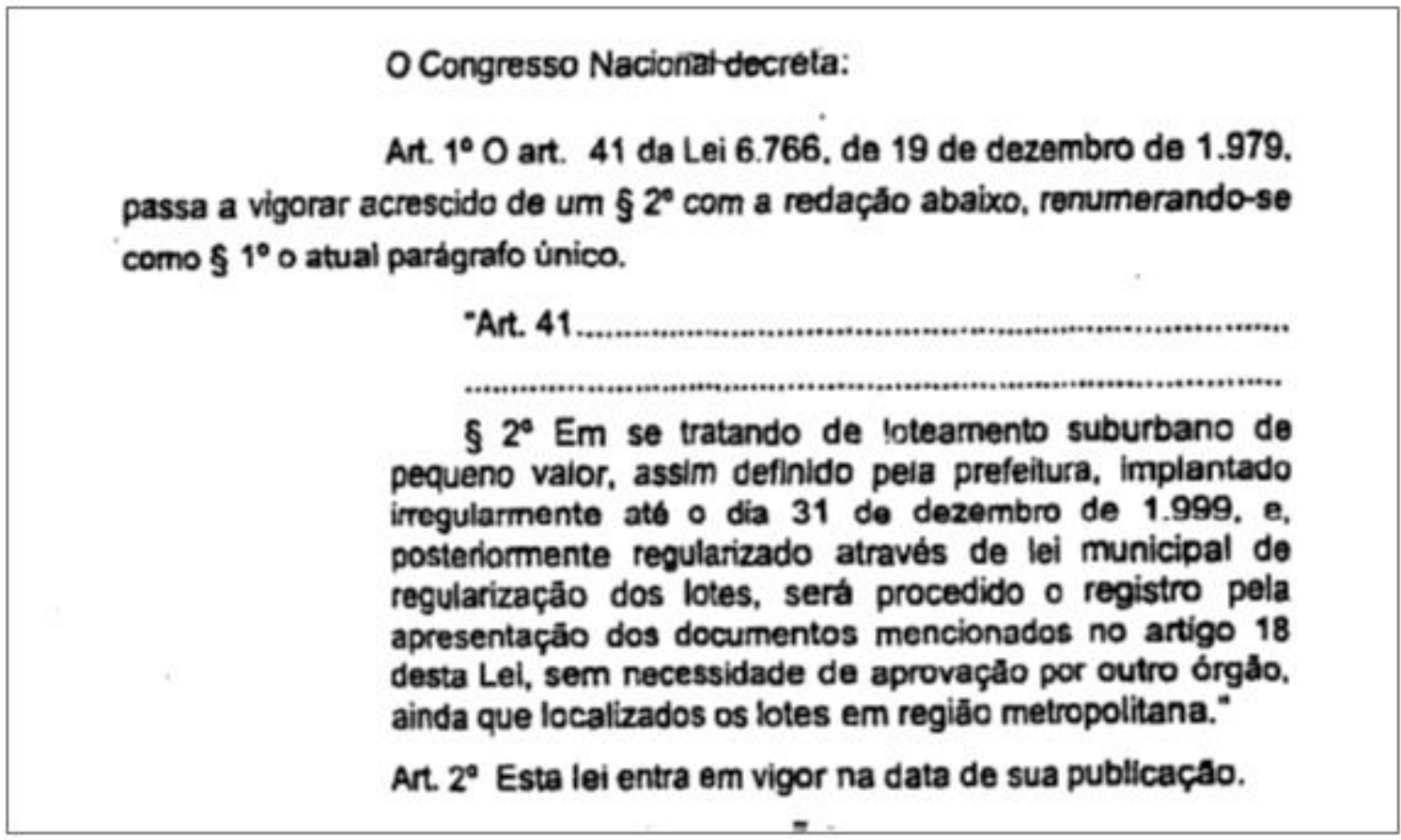

Autoria: Deputado Federal Bispo Wanderval.

O Grupo de Análise e Aprovação de Projetos Habitacionais (GRAPROHAB) foi criado pelo Decreto Paulista no. 33.499, em 10 de julho de 1991, e constitui um grupo colegiado que tem por escopo centralizar e agilizar os trâmites dos projetos 
habitacionais, que são apresentados para apreciação no âmbito do Estado. Esse colegiado é composto pelos seguintes órgãos do estado: I - Secretaria da Habitação; II - Secretaria da Saúde; III - Secretaria do Meio Ambiente; IV - Procuradoria Geral do Estado; V - Companhia de Tecnologia de Saneamento Ambiental (CETESB), VI Companhia de Saneamento Básico do Estado de São Paulo (SABESP); VII Eletricidade de São Paulo S/A (ELETROPAULO); VIII - Companhia de Gás de São Paulo (COMGAS); IX - Companhia Energética de São Paulo (CESP); X - Companhia Paulista de Força e Luz (CPFL); XI - Empresa Metropolitana de Planejamento da Grande São Paulo (EMPLASA); e XII - Corpo de Bombeiros da Polícia Militar.

Ocorre que, pela ausência de legislações específicas de regularização fundiária e, principalmente, pela função precípua de aprovação de empreendimentos novos, os projetos de regularização fundiária contavam com dificuldades extremas de aprovação. Assim, é bem provável que a inciativa legislativa do Deputado Bispo Wanderval tenha tido endereço certo: possibilitar o registro da regularização fundiária, sem que que fosse exigida a Certidão de aprovação do GRAPROHAB. Fato é que, com a criação do Ministério das Cidades em um governo que tinha por marca ser democrático e participativo, surge a preocupação com a criação de um marco urbanístico normativo em substituição à defasada Lei ‥ 6.766 de 1979. No bojo das amplas discussões nesse começo dos anos do 2000, logo após o Estatuto da Cidade, por iniciativa do Ministério das Cidades por meio da Secretaria de Programas Urbanos, foi elaborado, em conjunto com o Congresso, a revisão da Lei Lehmann (Lei no. 6.766).

Dessa forma, o original Projeto de Lei ํ․ 3.057 de 2000 passa a contar com uma estrutura robusta, apta a efetivar a substituição da atual lei de parcelamento do solo urbano. Dentre as matérias que foram disciplinadas pelo Projeto de Lei ㄲo. 3.057, enumeremos as seguintes: a) os requisitos urbanísticos e ambientais do parcelamento do solo urbano; b) as responsabilidades do empreendedor e do Poder Público na implantação e manutenção do parcelamento do solo; c) os requisitos e critérios sobre o conteúdo e para fins de aprovação do projeto do parcelamento do solo; d) as competências do Município e do Estado sobre licenciamento para parcelamento do solo; e) as exigências para a adoção da licença urbanística e ambiental integrada, bem como para a entrega das obras e da licença final integrada; f) os critérios para o 
registro do parcelamentos do solo; g) as regras para os contratos, h) as relações de consumo e direito do consumidor em parcelamento do solo; i) a regularização fundiária sustentável em área urbana, j) a regularização fundiária de interesse específico, k) a demarcação urbanística e legitimação de posse, I) o registro da regularização fundiária de interesse social; $\mathrm{m}$ ) as infrações penais, administrativas e civis sobre 0 parcelamento do solo; n) os requisitos e critérios para implantação e regularização do loteamento com controle de acesso; o) os critérios sobre o custo do registro dos títulos inerentes ao parcelamento; e p) a regularização fundiária de interesse social.

Vale destacar que o projeto de lei de responsabilidade territorial urbana foi amplamente discutido com diversos segmentos sociais afetos à reforma e urbana, tais como institutos de pesquisa, universidades, movimentos de moradia, entidades de classe, profissionais da área com formações diversas, gestores do poder público, registradores imobiliários, ministério público, e setores produtivos. Mesmo assim, não alcançou consenso. O setor produtivo barganhava a inclusão do capítulo da regularização fundiária em troca de anistia quase que irrestrita aos condomínios fechados por eles produzidos e as entidades ambientalistas não admitiam o licenciamento ambiental pelos municípios e a flexibilização das regras ambientais para regularização fundiária em área de preservação permanente. Com o ingresso do Ministério da Justiça nas discussões, a tentativa do setor produtivo de elaborar regras de perdimento quase que integral do valor pago em caso de desistência do comprador do lote ou unidade autônoma - regras de distrato - com claras máculas ao Código de Defesa do Consumidor, perde força, e o jogo empaca. Diante de tal dilema, a Secretaria de Patrimônio da União, que também estava revisando sua legislação, incluiu o importante instituto da demarcação urbanística e outros mais que constavam do PL nº. 3.057 de 2000, dando origem à Lei no. 11.481 em 31 de maio de 2007.

Da mesma forma, diante do impasse criado pelos jogos de interesses dos diversos setores envolvidos, precipuamente dos interesses do setor produtivo, foi editada a Medida Provisória no 459 de 25 de Março de 2009, dispondo da criação do Programa Minha Casa Minha Vida. Ocorre que, para além da criação do Programa, o governo federal conseguiu incluir o Capítulo III, tratando especificamente da Regularização Fundiária de Assentamentos Informais Urbanos, surgindo assim um conjunto de normas específicas de regularização fundiária urbana. Este foi 
amplamente festejado pelos setores sociais mais progressistas, passando quase desapercebida a iracúndia dos setores que se sentiram alijados com tal inclusão. Entretanto, estes souberam aguardar o contexto oportuno para o devido revide, como veremos.

\section{DO CAP. III DA LEI №. 11.977 DE 2009}

A Política Nacional de apoio à regularização fundiária surge com a criação do Ministério das Cidades, em 2003, com décadas de atraso - haja vista que os processos de ocupação irregular das cidades e de suas regiões metropolitanas intensificaram-se a partir da década de 70, como pudemos ver. De fato, a preponderância do Estado, de acordo com a repartição de poderes constitucional, na produção do espaço urbano é inegável. É dele o controle da regulamentação, o controle sobre o solo e sobre a ocupação do solo, considerando o arranjo federativo de distribuição de competências legislativa e material.

A primeira norma geral de regularização fundiária urbana foi o Capítulo III da Lei Federal nํ. 11.977 de 2009, originado da Medida Provisória nํ. 459, de 2009. Essa legislação caracterizava-se por: a) ser a primeira norma nacional de regularização fundiária; b) estabelecer princípios e procedimentos próprios de regularização fundiária urbana; c) reafirmar a competência municipal para o estabelecimento de programas e procedimentos de regularização fundiária urbana, incluindo o licenciamento urbanístico e ambiental; d) criar procedimentos para novos instrumentos de regularização fundiária e titulação: demarcação fundiária e legitimação de posse e sua conversão em direito de propriedade, de uso exclusivo pelos municípios; e) criar regras de registro de imóveis visando o registro dos projetos de regularização fundiária urbana.

Efetivamente, é inegável o protagonismo do município nos procedimentos de regularização fundiária após a Lei 11.977/09. Nesse sentido:

A nova Lei estabelece que o Município passe a protagonizar as ações que conduzirão, junto ao Ofício de Imóveis competente, à demarcação da gleba que foi objeto de parcelamento, e por elas responsável, cuidando da apuração dos seus limites e área, definindo sua localização exata, além da 
identificação dos seus confrontantes (...). (SARTORETTO; HERNANDES; LUZ, 2013, p. 161).

Embora já estivesse previsto no Estatuto da Cidade, a Lei no. 11.977 de 2009 estabeleceu nacionalmente o conceito de Zona Especial de Interesse Social (ZEIS). Além desses aspectos, ela introduziu pela primeira vez a distinção entre regularização fundiária de interesse social, voltada para assentamentos de baixa renda, e de regularização fundiária de interesse específico, tendo por objeto assentamento de média e alta renda. A fim de dar concretude a esse novo marco normativo, foi estabelecido o conceito de regularização fundiária a partir da definição doutrinária clássica da renomada jurista Betânia Alfonsin:

Regularização fundiária é o processo de intervenção pública, sob os aspectos
jurídico, físico e social, que objetiva legalizar a permanência de populações
moradoras de áreas urbanas ocupadas em desconformidade com a lei para
fins de habitação, implicando acessoriamente melhorias no ambiente urbano
do assentamento, no resgate da cidadania e da qualidade de vida da
população beneficiária. (ALFONSIN, 1997, p. 37 )

Dessa forma, essa definição doutrinária, que já vinha sendo largamente utilizada nas práticas de regularização fundiária, passa a ser incorporada ao ordenamento jurídico brasileiro por meio do art. 46 da Lei Federal n‥ 11.977 de 2009, como um caminho para a construção do marco legal para política pública nas terras urbanas brasileiras. Também são apresentadas algumas outras formulações. A primeira delas é o conceito de área urbana como parcela do território, contínua ou não, incluída no perímetro urbano pelo Plano Diretor ou por lei municipal específica (art. 47, I). A segunda se trata do conceito de área urbana consolidada como parcela da área urbana com densidade demográfica superior a 50 (cinquenta) habitantes por hectare e malha viária implantada e que tenha, no mínimo, 2 (dois) dos seguintes equipamentos de infraestrutura urbana implantados: a) drenagem de águas pluviais urbanas; b) esgotamento sanitário; c) abastecimento de água potável; d) distribuição de energia elétrica; ou, e) limpeza urbana, coleta e manejo de resíduos sólidos (art. 47, II). Por último, temos a definição assentamentos irregulares: ocupações inseridas em parcelamentos informais ou irregulares, localizadas em áreas urbanas públicas ou privadas, utilizadas predominantemente para fins de moradia (art. 47, VI). 
Estabeleceu-se ainda o conteúdo mínimo do projeto de regularização: I - as áreas ou lotes a serem regularizados e, se houver necessidade, as edificações que serão relocadas, II - as vias de circulação existentes ou projetadas e, se possível, as outras áreas destinadas a uso público; III - as medidas necessárias para a promoção da sustentabilidade urbanística, social e ambiental da área ocupada, incluindo as compensações urbanísticas e ambientais previstas em lei, IV - as condições para promover a segurança da população em situações de risco; e, IV - as condições para promover a segurança da população em situações de risco, considerado o disposto no parágrafo único do art. 3ํㅡㄹ da Lei № 6.766, de 19 de dezembro de 1979; e, V - as medidas previstas para adequação da infraestrutura básica.

Esse conteúdo mínimo do projeto de regularização fundiária previsto na legislação em apreço, esclareça-se, não se caracteriza como de atendimento obrigatório pelos municípios. Fez-se como uma espécie de norma padrão nos casos de municípios que não tivessem a obrigatoriedade constitucional de elaboração de plano diretor e legislação urbanística decorrente, ou como norma de apoio a ser disponibilizada na elaboração de planos diretores ou de legislações outras de planejamento urbano dos municípios que assim tivessem tal interesse.

Salienta-se que, em 2005, o Conselho Nacional das Cidades instituiu a Resolução ํo. 25/05, determinando o conteúdo mínimo dos planos diretores municipais. Contudo, por ser anterior à edição da Lei ㄲo. 11.977/09, por óbvio não constam na resolução dispositivos atinentes a esta lei.

Fundamental ainda repisar o fato de que a regularização fundiária, até a edição da Lei Federal №. 11.977 de 2009, era processada por via judicial (apesar de ser caracterizado como procedimento administrativo). Com isso, os procedimentos eram disciplinados por meio de Provimentos emanados pelos Tribunais de Justiça, e seus registros por meio de mandados de registro da regularização fundiária expedidos pelo respectivo juiz corregedor. Também nesse aspecto, a Lei no. 11.977 de 2009 representou um grande avanço na medida em que desjudicializou o procedimento da regularização fundiária urbana, passando a ser processada diretamente junto ao Cartório de Registro de Imóveis, a requerimento do interessado: "Art. 65. O registro do parcelamento resultante do projeto de regularização fundiária de interesse social 
deverá ser requerido ao registro de imóveis, acompanhado dos seguintes documentos." (Brasil, 2009).

Contudo, a edição de provimentos pelos Tribunais de Justiça, mesmo na vigência da Lei 11.977, continuou a disciplinar o registro dos projetos de regularização fundiária, mesmo após a edição da Lei no. 12.424 de 2011. Esta última alterou as leis no 11.977 de 2009 , no 10.188 de $2001, n^{\circ} 6.015$ de $1973, n^{\circ} 6.766$ de 1979 , n 4.591 de $1964, n^{\circ} 8.212$ de 1991 e n 10.406 janeiro de 2002 (Código Civil). Para além disso, ela revogou dispositivos da Medida Provisória nํ⒉197-43, de 24 de agosto de 2001, e introduziu o "CAPÍTULO XII - DO REGISTRO DA REGULARIZAÇÃO FUNDIÁRIA URBANA" junto à Lei Nacional de Registros Públicos, Lei Federal 6.015 de 1973, estabelecendo, ineditamente, normas específicas de regularização fundiária.

Esses dispositivos, culminados com o Provimento no 44 de 18 de março de 2015, editado pelo Conselho Nacional de Justiça (CNJ), representaram um arcabouço legislativo consistente para a segurança do registro da regularização fundiária pelos Cartórios de Registro de Imóveis. Contudo, nota-se que, mesmo assim, durante a vigência da Lei 11.977 de 2009, com as alterações promovidas pela Lei no. 12.465, de 2011, 15 estados da Federação editaram Provimentos pelos seus respectivos tribunais de justiça. ${ }^{6}$

\section{DA LEI № $13.465 / 17$}

Em 31 de agosto de 2016 ocorreu o impeachment da presidente da República, rotacionando violentamente o rumo sócio-econômico-financeiro do país, passando o governo federal a representar claramente os interesses da elite econômica tradicional. Como amplamente debatido ao longo da presente, a história é cíclica e, em momento

\footnotetext{
${ }^{6}$ Os Tribunais de Justiça dos seguintes estados editaram provimentos normatizando o registro da regularização fundiária: AC - 10/2016 - Código Normas Extrajudiciais; PA - Código Normas Extrajudiciais (2015); RO - 026/2013 - Diretrizes Gerais Extrajudiciais; TO - 02/2013 - Manual de Normas Extrajudiciais; AL - 04/2015 - Projeto Moradia Legal; BA - 09/2013 - Código de Normas Extrajudiciais; MA - 11/2013 - Código de Normas; PB - 03/2015 - Código de Normas; PE - Código de Normas Extrajudiciais; PI - 09/2013 - Código de Normas Extrajudiciais; RN - 6/2016 - Código de Normas Extrajudiciais; MS Código de Normas (out/2016); MG 260/2013 e 327/2016 Código de Normas Extrajudiciais; RJ Portaria 86/2013; SP 58/89 e 37/2013 Normas de Serviço Extrajudiciais, e; RS - 32/06 e 26/16 - Código de Normas Extrajudicial
} 
de fragilidade democrática, inevitavelmente são editadas normas que pretendem regular o território, sempre com a promessa de resolução cabal da questão do nó da terra.

Como não poderia ser diferente, no final do ano de 2016, no dia 23 de dezembro, foi editada a Medida Provisória no. 759 pelo poder executivo federal, versando sobre inúmeras matérias relacionadas à questão da terra: regularização fundiária rural, regularização fundiária de áreas urbanas e procedimentos de avaliação e alienação de imóveis da união. Do ponto de vista das áreas urbanas, essa Medida Provisória representou grande repercussão nas potenciais formas de produzir as cidades e territórios. A MP № 759 de 2016 alterou 19 atos normativos federais editados entre os anos de 1946 e 2015, dentre os quais todas as disposições sobre regularização fundiária da Lei Federal n․ 11.977 de 2009 e os dispositivos sobre registro da regularização fundiária da Lei no. 6.015 de 1973, introduzidos pela Lei nº . 12.424 de 2011.

Desde a sua edição, a sociedade civil ativamente veio a se posicionar em relação à Medida Provisória no 759 de 2016, especialmente quanto a dispositivos atinentes à regularização fundiária urbana, participando de inúmeras audiências públicas, seminários e palestras. Dentre as entidades que participaram podemos elencar o Instituto Brasileiro de Direito Urbanístico (IBDU), o Instituto Pólis, o Laboratório de Urbanismo da USP (LabHab), a União dos Movimentos de Moradia (UMM), o Conselho de Arquitetura e Urbanismo (CAU), o Instituto de Arquitetura Brasileiro (IAB), a Federação Nacional dos Arquitetos (FNA), o Núcleo de Moradia da Defensoria Pública de São Paulo, o Instituto dos Registradores Imobiliários do Brasil (IRIB) e a Associação dos Registradores Imobiliários de São Paulo (ARISP). Todos esses debates foram fundamentais e, em certa medida, contribuíram para a edição do Projeto de Lei Complementar n 12/2017, da lavra do Senador Romero Jucá, que introduziu alterações substanciais à redação originada da Medida Provisória nํㅜ 759 de 2016.

Em 11 de julho de 2017, foi publicada a Lei no 13.465, com 109 artigos, versando sobe a Regularização Fundiária Urbana no Título II, arts. 9a ao 82. Alcunhada como a "nova lei da regularização fundiária", a lei especifica duas 
modalidades de regularização: a REURB S, que se aplica à regularização fundiária de interesse social voltada aos assentamentos de população de baixa renda, e a REURB $\mathrm{E}$, que se aplica à regularização fundiária de interesse específico - que tem por alvo os assentamentos formados por população de média e alta renda. Seguindo a linha da Lei ํo. 11.977 de 2009, a Lei №. 13.465 estabelece alguns conceitos, altera e cria instrumentos urbanísticos de regularização fundiária.

\subsection{DEFINIÇÕES DA LEI - ART. 11, LEI №. 13.465/17}

A exemplo da Lei ㄲo. 11.977. de 2009, essa nova norma traz definições e conceitos, muitos deles rebatizados com nova nomenclatura, mantendo a essência da legislação revogada. As principais definições são as seguintes:

a. Núcleo Urbano: assentamento humano, com uso e características urbanas, constituído por unidades imobiliárias de área inferior à fração mínima de parcelamento prevista na Lei no 5.868, de 12 de dezembro de 1972, independentemente da propriedade do solo, ainda que situado em área qualificada ou inscrita como rural;

b. Fração Mínima de Parcelamento: Medida da área do terreno determinada por cada município, podendo variar de 2 hectares (20 mil metros quadrados) até a 5 hectares (50 mil metros quadrados). A ausência de padrão de FMP adequa-se a realidade de cada município, e as informações específicas podem ser encontradas no site do Incra. No caso da Lei 13.465/17, a limitação da FMP se dá para cada unidade/moradia dentro do núcleo urbano, e não ao núcleo urbano como um todo (vide art.11, § 6º);

c. Núcleo Urbano Informal: aquele clandestino, irregular ou no qual não foi possível realizar, por qualquer modo, a titulação de seus ocupantes, ainda que atendida a legislação vigente à época de sua implantação ou regularização;

d. Núcleo Urbano Informal Consolidado: aquele de difícil reversão, considerados o tempo da ocupação, a natureza das edificações, a localização das vias de circulação e a presença de equipamentos públicos, entre outras circunstâncias a serem avaliadas pelo Município;

e. Certidão de Regularização Fundiária (CRF): documento expedido pelo Município ao final do procedimento da Reurb, constituído do projeto de regularização fundiária aprovado, do termo de compromisso relativo a sua 
execução e, no caso da legitimação fundiária e da legitimação de posse, da listagem dos ocupantes do núcleo urbano informal regularizado, da devida qualificação destes e dos direitos reais que lhes foram conferidos;

f. REURB-S e REURB-E: As duas modalidades de procedimento apresentadas pela lei às prefeituras dividem-se entre a de Interesse Social (S) e Interesse Específico (E). A REURB-S é destinada aos núcleos urbanos informais consolidados ocupados predominantemente por população de baixa renda. A determinação de que uma área de uma cidade deve ser alvo de uma REURB-S se dá por meio de declaração da Prefeitura competente (ato discricionário). Enquanto as obras, levantamentos, estudos, taxas e tributos próprios do procedimento serão pagos pelo município em caso de uma REURB-S, a REURB-E deverá ser integralmente custeada pelos proprietários interessados na regularização de sua propriedade;

g. Demarcação Urbanística: procedimento destinado a identificar os imóveis públicos e privados abrangidos pelo núcleo urbano informal e a obter a anuência dos respectivos titulares de direitos inscritos na matrícula dos imóveis ocupados, culminando com averbação na matrícula destes imóveis da viabilidade da regularização fundiária, a ser promovida a critério do Município, visando à criação de lote único para aprovação e registro de projeto de regularização fundiária;

h. Infraestrutura Essencial: a) sistema de abastecimento de água potável;

b) coletivo ou individual; c) sistema de coleta e tratamento do esgotamento sanitário, coletivo ou individual; d) rede de energia elétrica domiciliar; e) soluções de drenagem, quando necessário; e f) outros equipamentos a serem definidos pelos poder público em função das necessidades locais;

i. Legitimação Fundiária - legitimação fundiária constitui forma originária de aquisição do direito real de propriedade conferido por ato do poder público, exclusivamente no âmbito da Reurb, àquele que detiver em área pública ou possuir em área privada, como sua, unidade imobiliária com destinação urbana, integrante de núcleo urbano informal consolidado existente em 22 de dezembro de 2016;

j. Legitimação de Posse: ato do poder público destinado a conferir título, por meio do qual fica reconhecida a posse de imóvel objeto de regularização fundiária, conversível em aquisição de direito real de propriedade na forma desta Lei. (Brasil, 2009). 


\title{
10.2 LEGITIMADOS PARA REQUISIÇÃO DA REURB
}

A Lei no. 13.465 de 2017 amplia o rol dos legitimados para requerer a REURB, incluindo a Defensoria Pública e o Ministério Público, informando, assim, em seu art. 14:

\begin{abstract}
Poderão requerer a Reurb:
I - a União, os Estados, o Distrito Federal e os Municípios, diretamente ou por meio de entidades da administração pública indireta;

II - os seus beneficiários, individual ou coletivamente, diretamente ou por meio de cooperativas habitacionais, associações de moradores, fundações, organizações sociais, organizações da sociedade civil de interesse público ou outras associações civis que tenham por finalidade atividades nas áreas de desenvolvimento urbano ou regularização fundiária urbana;

III - os proprietários de imóveis ou de terrenos, loteadores ou incorporadores; IV - a Defensoria Pública, em nome dos beneficiários hipossuficientes; e V - o Ministério Público.

Os legitimados acima poderão promover todos os atos necessários à regularização fundiária, inclusive requerer os atos de registro.

Nos casos de parcelamento do solo, de conjunto habitacional ou de condomínio informal, empreendidos por particular, a conclusão da Reurb confere direito de regresso àqueles que suportarem os seus custos $e$ obrigações contra os responsáveis pela implantação dos núcleos urbanos informais.

O requerimento de instauração da Reurb por proprietários de terreno, loteadores e incorporadores que tenham dado causa à formação de núcleos urbanos informais, ou os seus sucessores, não os eximirá de responsabilidades administrativa, civil ou criminal. (Brasil, 2017).
\end{abstract}

Concretamente, não obstante a ampliação daqueles que podem requerer a REURB, com efeito, "os pesos e medidas" não se encontram devidamente balanceados no que tange a responsabilidade pelo processamento da regularização fundiária. A Prefeitura, nos casos de REURB $S$, deve arcar não apenas com a iniciativa, mas também com o licenciamento e com a elaboração de todos os projetos, o que foge à alçada da Defensoria Pública e do Ministério Público e se mostra 
absolutamente inviável financeiramente à população alvo que reside no assentamento.

\subsection{PROCESSAMENTO ADMINISTRATIVO DO REQUERIMENTO}

A Lei №. 13.465 de 2017 prevê um completo fluxo procedimental junto às instâncias administrativas. Essa matéria é muito importante para municípios que ainda não possuem legislação própria de regularização fundiária, pois tem o potencial de balizar os mesmos quanto às etapas e atos administrativos mínimos que a administração pública deve atender. Contudo, esse não é caso do Município de São Paulo, que já possui normas próprias e órgão gestor da regularização fundiária - a saber, a Coordenadoria de Regularização Fundiária (CRF) - com departamentos e fluxos próprios, há décadas, desde SERLA, passando por RESOLO, e agora CRF. A escala de processos de regularização fundiária, somada à expertise resultante de décadas de experiência da CRF em São Paulo, decerto a autorizam a não adotar os procedimentos previstos na lei federal; de todo modo, sintetizamos abaixo quais são esses procedimentos.

Instaurada a REURB, o Município deverá proceder às buscas necessárias para determinar a titularidade do domínio dos imóveis onde está situado o núcleo urbano informal a ser regularizado, verificando, especialmente, no Cartório de Registro de Imóveis, a origem do imóvel através de sua cadeia sucessória (art. 31, Lei de Reurb). Tratando-se de imóveis públicos ou privados, caberá aos Municípios notificar os titulares do domínio, os responsáveis pela implantação do núcleo urbano informal, os confinantes e os terceiros eventualmente interessados, para apresentar impugnação no prazo de trinta dias, contado da data de recebimento da notificação. Tratando-se de imóveis públicos municipais, o Município deverá notificar os confinantes e terceiros eventualmente interessados, para, querendo, apresentar impugnação no prazo de trinta dias, contado da data de recebimento da notificação. Se apresentada impugnação, será iniciado o procedimento extrajudicial de composição de conflitos de que trata a Lei de Reurb. A notificação do proprietário e dos confinantes será feita por via postal, com aviso de recebimento, no endereço que constar da matrícula ou da transcrição, considerando-se efetuada quando comprovada a entrega nesse 
endereço. A notificação da Reurb também será feita por meio de publicação de edital, com prazo de trinta dias, do qual deverá constar, de forma resumida, a descrição da área a ser regularizada, quando o proprietário e os confinantes não forem encontrados e quando houver recusa da notificação por qualquer motivo. A ausência de manifestação será interpretada como concordância com a Reurb. Caso algum dos imóveis atingidos ou confinantes não esteja matriculado ou transcrito na serventia, o Distrito Federal ou os Municípios realizarão diligências perante as serventias anteriormente competentes, mediante apresentação da planta do perímetro regularizado, a fim de que a sua situação jurídica atual seja certificada, caso possível. O requerimento de instauração da Reurb ou, na forma de regulamento, a manifestação de interesse nesse sentido, por parte de qualquer dos legitimados, garante, perante o poder público, aos ocupantes dos núcleos urbanos informais situados em áreas públicas a serem regularizados, a permanência em suas respectivas unidades imobiliárias, preservando-se as situações de fato já existentes, até o eventual arquivamento definitivo do procedimento. A lei dispensa o procedimento de notificação, caso adotados os procedimentos da demarcação urbanística.

A definição de procedimentos para a regularização está sendo objeto da Ação Direita de Inconstitucionalidade $\mathrm{n} \div$. 5.883, que se encontra tramitando junto ao Supremo Tribunal Federal. Essa ação foi promovida pelo Instituto dos Arquitetos do Brasil, em face à Lei no. 13.485 de 2017, sob o fundamento de que não caberia à União, e sede de norma geral, impor procedimentos aos Municípios, sob pena de ruptura do pacto federativo:

Outro dado relevante é que a Lei esmiúça no Capítulo III do Título II o procedimento administrativo a ser seguido pelos Municípios, restringindo suas escolhas a atos burocráticos de implementação da regularização e tornando, assim, sua competência executiva em meramente administrativa. (...) Tem-se, assim, que a Lei em questão, ao definir e tratar da Regularização Fundiária Urbana (Reurb), em diversos dispositivos centrais (art. 9º caput; art. 11, I; Capítulo III - Do Procedimento Administrativo; dentre outros), e também em seus silenciamentos, não se volta, como deveria, à regulamentação abstrata e nacional de princípios e determinações constitucionais da política urbana, imprimindo específico contorno social, econômico ou ambiental à matéria. Pelo contrário, consubstancia-se em 
verdadeiro manual de implementação passo a passo da Reurb para os Municípios, deixando pouca ou nenhuma escolha a quem a Constituição erigiu como protagonista do planejamento urbano; e impondo que o Plano Diretor e o contorno territorial das cidades se moldem à norma, em antagonismo aos ditames constitucionais. Consegue, desse modo, a um só tempo violar a competência executiva e normativa municipal. (Brasil, 2018).

\subsection{EXPEDIÇÃO DA CRF PELO MUNICÍPIO}

Segundo informado pela Lei №. 13.465/17, a Certidão de Regularização Fundiária (CRF) é o ato administrativo de aprovação da regularização que deverá acompanhar o projeto aprovado, e deve conter no mínimo:

I. o nome do núcleo urbano regularizado;

II. a localização;

III. a modalidade da regularização;

IV. as responsabilidades das obras e serviços constantes do cronograma;

V. a indicação numérica de cada unidade regularizada, quando houver;

VI. a listagem com nomes dos ocupantes que houverem adquirido a respectiva unidade, por título de legitimação fundiária ou mediante ato único de registro, bem como o estado civil, a profissão, o número de inscrição no cadastro das pessoas físicas do Ministério da Fazenda (CPF) e do registro geral da cédula de identidade (RG) e a filiação.

A Prefeitura de São Paulo, por meio da Coordenadoria de Regularização Fundiária da Secretaria de Habitação, ainda hoje utiliza o Auto de Regularização Fundiária com planta $\mathrm{AU}$ correspondente, estando em fase de transição para a expedição de CRF, nos moldes da lei federal.

Decerto, os efeitos da uniformização da nomenclatura dos antigos autos de regularização, em nível nacional, ainda são incertos em face do pouco tempo da edição da lei federal, e certamente demandará alterações legislativas em nível local.

\subsection{INSTITUTOS CRIADOS PELA LEI №. 13.465/17}


Além da Legitimação fundiária, cujo conceito vimos acima, a lei federal introduziu alguns outros institutos de direito urbanístico. São eles:

a. Direito de Laje: foi introduzido o direito real de laje no rol dos direitos reais (art. 1.225 do Código Civil) por meio do art. 55. A lei menciona a cessão de superfície e traz regras ampliadas, frente à medida provisória anterior, além de apresentar a possibilidade de abertura de matrícula individual para moradias sobrepostas. Isso foi possível porque fora promovida também alterações na Lei de Registros Públicos:

Art. 176. § 9‥ A instituição do direito real de laje ocorrerá por meio da abertura de uma matrícula própria no registro de imóveis e por meio da averbação desse fato na matrícula da construção-base e nas matrículas de lajes anteriores, com remissão recíproca. (Brasil, 2017).

b. Condomínio de lotes: introduziu alterações no código civil, com aplicação subsidiária das mesmas regras do condomínio edilício. As principais características são: (i) é aplicável apenas a empreendimentos novos, portanto não é cabível como instrumento de regularização fundiária; (ii) altera a 6766, de 1979 - art. $2^{\circ}$. $\S 7^{0}$ - o lote poderá ser constituído sob a forma de imóvel autônomo ou de unidade imobiliária integrante de condomínio de lotes; (iii) é aplicável exclusivamente a condomínios horizontais; (iii) terá Instituição de condomínio nos termos da Lei n‥ 4591/64; (iv) altera a Lei no 6.766 de 1979 - art. 2ํ․, § 4ำ - no caso de lotes integrantes de condomínios de lotes, poderão ser instituídas limitações administrativas e direitos reais sobre coisa alheia em benefício do poder público, da população em geral e da proteção da paisagem urbana, tais como servidões de passagem, usufrutos e restrições à construção de muros.

c. Obrigatoriedade no pagamento das despesas de conservação nos condomínios fechados: promoveu modificações na Lei №. 6.766, de 1979. Essa obrigatoriedade afasta a jurisprudência anterior consolidada do STF e do STJ, que se inclinavam em sentido contrário à essa norma.

d. Conjuntos habitacionais informais: estipula regras gerais de regularização fundiária de conjuntos habitacionais. Aliadas às normas municipais, constitui-se importante ferramenta para regularização de conjuntos habitacionais promovidos 
pelo poder público, tais como aqueles implantados pela COHAB/SP e pela $\mathrm{CDHU}$, ou pelo PROVER e pelo PROCAV, inclusive com dispensa de habite-se.

e. Condomínio urbano simples, com aplicação para habitações coletivas: as principais características são (i) CONDIÇÃO - Aprovação mediante Legislação Municipal, não requer habite-se; (ii) PROJETO - Representação gráfica e memorial, descritivo das áreas ocupadas por edificação e via interna; (iii) REURB - não precisa ser REURB; (iv) LEGISLAÇÃO - Aplicação Subsidiária dos dispositivos de condomínio edilício do Código Civil.

f. Regulamentação da arrecadação de imóveis abandonados, na forma do art. 1.276 do Código Civil. A arrecadação de imóveis já estava prevista no Código Civil como uma das formas de perdimento da propriedade, ao lado da alienação, da renúncia, do perecimento da coisa e da desapropriação. Contudo, uma das lacunas desse dispositivo que inviabilizava sua aplicação era não haver previsão legal da caracterização do abandono. Essa questão foi resolvida pela Lei ㄲo. 13.465 de 2017, ao prever que há pressuposto do abandono do imóvel quando o proprietário deixa de adimplir os ônus fiscais instituídos sobre a propriedade predial e territorial urbana por cinco anos, cessados os atos de posse sobre o imóvel. A lei traz ainda detalhamento sobre o procedimento de notificação do proprietário e informa quais serão as possibilidades de utilização do imóvel arrecadado pelo município, que, dentre outras, pode ter por finalidade o fomento a REURB.

g. Mudança na redação do artigo que trata da usucapião coletiva, no Estatuto da Cidade (art. 10). A forma de configuração do direito à usucapião coletiva foi alterada profundamente em relação à redação original do Estatuto da Cidade. Assim, essa nova redação trouxe critérios mais concretos ao instrumento.

h. Concessão de Uso Especial para fins de Moradia (CUEM): foi alterado o marco legal. O morador de área pública, para ter o direito subjetivo à CUEM, deve residir na área há cinco anos contados de 22 de dezembro de 2016. Contudo, se o Município contar com outro marco legal, o que vale para suas áreas públicas é o marco legal da legislação municipal, que é o caso de São Paulo. Esse critério também vale para estabelecimentos comerciais cujo título a que fazem jus é a autorização de uso. Os critérios para caracterização da concessão de uso especial 
para fins de moradia coletiva também foram alterados de forma análoga à alteração promovida na usucapião coletiva.

Não obstante terem sido criados inúmeros institutos urbanísticos novos e alterados substancialmente outros, o importante a ressaltar é que a maioria deles, para ser aplicado pelo município, carece de lei municipal que estabeleça regras próprias a partir das normas gerais ditadas pela Lei no . 13.465/17. Portanto, esses institutos são de difícil aplicabilidade direta em Municípios de grande porte, o que poderá ser resolvido pela elaboração e revisão das normas urbanísticas em vigência. Por fim, é importante mencionar que a Lei no. 13.465 de 2017 foi regulamentada pelo Decreto no 9.310, de 15 de março de 2018, que institui as normas gerais e os procedimentos aplicáveis à Regularização Fundiária Urbana e estabelece os procedimentos para a avaliação e a alienação dos imóveis da União.

Embora a Lei no․ 13.465 de 2017 tenha surgido com um apelo à "simplicidade" de procedimentos, celeridade, e desburocratização", atributos amplamente divulgados na imprensa - até fevereiro de 2020, um pouco mais de dois anos da edição da lei, os tribunais de justiça dos seguintes estados trataram de editar normas para registro da regularização fundiária, com fundamento na Lei № 13.465 de 2017: Bahia Provimento Conjunto CGJ/CCI № 03/2020; Maranhão - Provimento 292.019/2019; Pernambuco - Provimento Conjunto no 01 de 31 de maio de 2018; Piauí - Provimento 36 - Programa-Regularizar; Rio Grande do Norte - Provimento no 198 de 04 de fevereiro de 2020 - CGJ/RN; e São Paulo - Provimento 56/19. Isto denota que, apesar da "simplicidade" de procedimentos, festejada pelos autores da lei federal, talvez seja ausente ou insuficiente a necessária regulação registral da matéria em nível nacional.

\section{CONCLUSÕES}

Conforme foi possível de perceber, o entendimento sobre "regularizar" e os procedimentos para tanto vão se alterando ao longo da história.

No decorrer do tempo percebe-se como a leitura do que é a irregularidade vai sendo entendida e de como ela se manifesta nas cidades e particularmente na região Metropolitana de São Paulo como a alternativa de assentamento popular. 
Em quase dois séculos de legislações de parcelamento do solo e, mais precisamente, nas últimas décadas com a introdução de normas específicas de regularização fundiária urbana junto ao ordenamento jurídico, a conclusão mais evidente é que a história da ocupação dos territórios, desde sua origem, reflete um conflito de classes econômicas. Além disso, as "legislações territoriais", sejam elas de parcelamento do solo ou de regularização fundiária, são editadas majoritariamente para manutenção do poder hegemônico sobre a terra.

No Brasil colônia, a terra rural era fonte de acumulação de renda por meio da exploração extensiva; no Brasil do Império, também era fonte de acumulação de capital, expressa nos dividendos provenientes da plantação de café. Essa conta estaria fechada caso a abolição da escravatura não se impusesse pelas circunstâncias da política diplomática com a Inglaterra. Terras fartas conjugadas com homens livres são sinônimos de abandono de emprego e perda da mão de obra, desestruturando o sistema econômico que prescindia de mão de obra trabalhando na terra. O mesmo se diga em relação à mão de obra imigrante.

Portanto, a regulação das terras por meio da Lei de Terras garantiu, além da regularização fundiária das áreas ocupadas pelos posseiros, a hegemonia da elite cafeeira quanto ao domínio dos meios de produção. Durante o período republicano, houve o agravamento progressivo da questão da ausência de terras para moradia, especialmente nos centros urbanos, onde toda sorte de improvisos em forma de cortiços surgiram, agravando o quadro de epidemias à época. (BONDUKI, 2017). Ao longo do século XIX, as legislações mais preponderantes foram editadas sob regime de exceção, muitas delas imbuídas de ideologia nacionalista, mas, decerto, nenhuma delas com o objetivo de diminuir o déficit de terras ou déficit habitacional nos centros urbanos. Ou seja, as legislações produzidas ao longo do século XIX e XX não tiveram por mira a população de baixa renda. As consequências nefastas da ausência de planejamento territorial ocorrem a partir da década de 70 quando o país se torna majoritariamente urbano.

Podemos apontar com tranquilidade que as legislações produzidas a partir da Constituição Federal até 2016 foram as únicas originadas de processos democráticos, 
nas quais direitos humanos se sobrepõem à concepção de terra/moradia como fonte de renda. Estas compreendem a terra, mesmo que irregular, não como capital morto, como prenuncia Hernando de Sotto ${ }^{7}$, mas como concretização de direitos subjetivos, como o direito à moradia, alicerce da Lei Federal n… 11.977, de 2009.

A recente Lei no. 13.465 de 2017, inspirada nos ideais peruanos de regularização fundiária para promoção de capital imobiliário, demonstra em sua exposição de motivos a que veio, deixando clara a vertente financeira da regularização fundiária:

87. Nos parágrafos seguintes, serão destacadas, por tópicos, as principais mudanças sugeridas para o tema da regularização fundiária urbana. Antes, porém, convém ressaltar importante aspecto econômico que, também, serve à legitimação desta proposta de Medida Provisória.

88. É que o reconhecimento, pelo Poder Público, dos direitos reais titularizados por aqueles que informalmente ocupam imóveis urbanos, permite que estes imóveis sirvam de base para investimento do capital produtivo brasileiro, à medida que poderão ser oferecidos em garantia de operações financeiras, reduzindo custos de crédito, por exemplo.

89. Também, a regularização fundiária urbana contribui para o aumento do patrimônio imobiliário do País e representa a inserção de capital na economia, à medida que agrega valor aos imóveis regularizados, os quais, inclusive, tornam-se alvo de tributação (IPTU, ITR, ITBI) ou de cobrança de preços públicos (foros e laudêmios). (...)

103. Referido instrumento serve tanto aos propósitos de garantia do direito real de moradia, bem como de garantia dos fins sociais das cidades. Eis a razão pela qual são objeto de regularização fundiária, com os limites da proposta de Medida Provisória em tela, não só as habitações, mas também imóveis destinados a outras atividades típicas de qualquer cidade, a exemplo de atividades profissionais ou comerciais. Tudo a estimular os mercados

7 Conforme FERNANDES, 2006: na origem de tal movimento estão as ideias do economista peruano Hernando de Soto, que é, seguramente, um dos ideólogos mais influentes do momento. Seus livros "O outro caminho" e "O mistério do capital" já viraram best-sellers em muitos países e são frequentemente aclamados em editoriais de publicações influentes como The Economist, The Financial Times e The New York Times. Diversos países têm traduzido as propostas de Soto em políticas públicas nacionais de regularização fundiária em grande escala - Peru, México, El Salvador, Egito, Romênia, dentre outros -, sobretudo por exigência do Banco Mundial. (FERNANDES, Edésio. Regularização Fundiária Plena: Referências Conceituais. Brasília: Ministério das Cidades, 2006). 
locais e a manter os beneficiários nos locais originalmente ocupados. (Brasil, 2017, grifo nosso).

É importante frisar que a Lei oㅡ. 13.465 de 2017, a par de sua concepção tendo em mira a entrada de capital imobiliário no mercado, regulou de forma ostensiva a produção habitacional de média e alta renda, denominada norma como REURB-E, alargando as estratégias normativas previstas na Lei №. 11.977 de 2009 para a regularização de interesse específico. Exemplo é a alteração trazida pela Lei №. 13.465 promovida junto ao Código Florestal no art. 65, de modo a estender 0 licenciamento ambiental para empreendimentos de média e alta renda, com relativa flexibilidade a normas previstas no Código Florestal para supressão de APP (TIERNO, 2018). Vale ainda mencionar que a oportunidade perdida pelo setor produtivo com a edição da Medida Provisória no. 459 de 2009 foi amplamente recepcionada no texto da Lei ㄲo. 13.465 de 2017, especialmente com as alterações promovidas no Código Civil incorporando o instituto do condomínio edilício, o loteamento de acesso controlado e a normatização das associações de moradores de condomínios fechados, tornando-as aptas a receberem as taxas associativas. Isto além da própria regulação da REUB E todos os seus reflexos.

Contudo, as legislações urbanísticas, como supra exposto, possuem a peculiaridade de perpassar os diversos entes federativos. O Plano Diretor, ainda, é o instrumento básico da política de desenvolvimento e de expansão urbana municipal. Concluindo-se que as legislações urbanísticas são compostas por camadas de legislações, de acordo com a competência federativa para o trato da matéria. Além delas, no caso das normas de regularização fundiária, temos ainda os Provimentos emanados pelas Corregedorias Gerais de seus respectivos tribunais de justiça endereçados ao registro imobiliário.

As camadas de legislações se sobrepõem nos mesmos territórios das cidades, criando um emaranhado legislativo que acirra os conflitos hermenêuticos. Mas, sem dúvida, o principal conflito legislativo ainda é aquele que despreza a formação do território urbano. O histórico de legislações brasileiras com o escopo de regular o solo demonstra que, muito embora tenham sido editadas inúmeras normas, regulamentos, provimentos etc., o nó da terra está longe de ser desatado. De modo contrário, a 
edição de cada norma reflete a tutela da terra pelo poder hegemônico da época, em plena sintonia com os interesses econômicos em pauta. 


\section{BIBLIOGRAFIA}

ALFONSIN, Betânia, Direito à moradia: instrumentos e experiências de regularização fundiária nas cidades brasileiras. Rio de Janeiro: IPPUR/FASE, 1997.

BALTRUSIS, Nelson. Instrumentos urbanísticos e o acesso à terra urbana em Diadema: o caso das AEIS. Ambiente construído, v. 3, №. 4, p. 5-12, 2003. Disponível em: https://seer.ufrgs.br/ambienteconstruido/article/view/3507. Acesso em: 20 fev. 2020.

BONDUKI, Nabil. As Origens da Habitação Social no Brasil. São Paulo: Estação Liberdade, 2017, 7a. ed, p. 25-37.

BOSI, Alfredo. A escravidão entre dois liberalismos. Estudos Avançados, v. 2, n. 3, p. 4-39, 1 dez. 1988.

BRASIL. Constituição (1824). Constituição Política do Império do Brasil. Rio de Janeiro, RJ:

Secretaria de Estado dos Negócios do Império do Brasil, 1824.

BRASIL. Constituição (1988). Constituição da República Federativa do Brasil. Brasília, DF: Senado Federal, 1988.

BRASIL. Constituição (1988). Emenda constitucional no 26, de 14 de fevereiro de 2000. Altera a redação do art. 6ํำ da Constituição Federal. Brasília, DF: Senado Federal, 2000.

BRASIL. Decreto $\mathbf{n}^{\circ} \mathbf{1 . 3 1 8}$, de 30 de janeiro de 1854. Manda executar a Lei nํ 601, de 18 de setembro de 1850.

BRASIL. Decreto $\mathbf{n}^{\circ}$ 3.079, de 15 de setembro de 1938. Regulamenta o Decreto-Lei n. 58, de 10 de dezembro de 1937, que dispõe sobre o loteamento e a venda de terrenos para pagamento em prestações.

BRASIL. Decreto $\mathbf{n}^{\circ} \mathbf{9 . 3 1 0}$, de 15 de março de 2018. Institui as normas gerais e os procedimentos aplicáveis à Regularização Fundiária Urbana e estabelece os procedimentos para a avaliação e a alienação dos imóveis da União.

BRASIL. Decreto $\mathbf{n}^{\circ}$ 19.924, de 27 de abril de 1931. Dispõe sobre as terras devolutas.

BRASIL. Decreto-Lei $\mathbf{n}^{\circ} \mathbf{5 8}$, de 10 de dezembro de 1937. Dispôe sôbre o loteamento e a venda de terrenos para pagamento em prestações.

BRASIL. Decreto-Lei $\mathbf{n}^{\circ}$ 271, de 28 de fevereiro de 1967. Dispõe sôbre loteamento urbano, responsabilidade do loteador concessão de uso e espaço aéreo e dá outras providências.

BRASIL. Decreto-Lei n $^{\circ}$ 3.336, de 21 de junho de 1941. Dispõe sobre desapropriações por utilidade pública.

BRASIL. Decreto-Lei n 9.760, de 05 de setembro de 1946. Dispõe sôbre os bens imóveis da União e dá outras providências.

BRASIL. Lei $\mathbf{n}^{\circ} \mathbf{3 1 7}$, de 21 de outubro de 1843. Fixando a Despeza e orçando a Receita para os exercicios de 1843 - 1844, e 1844 - 1845.

BRASIL. Lei $\mathbf{n}^{\circ} \mathbf{6 0 1}$, de 18 de setembro de 1850. Dispõe sobre as Terras Devolutas do Império.

BRASIL. Lei $\mathbf{n}^{\circ} \mathbf{3 . 0 7 1}$, de $1^{\circ}$ de janeiro de 1916. Institui o Código Civil.

BRASIL. Lei $\mathbf{n}^{\circ} \mathbf{4 . 5 0 4}$, de 30 de novembro de 1964. Dispõe sobre o Estatuto da Terra, e dá outras providências.

BRASIL. Lei $\mathbf{n}^{\circ}$ 4.591, de 16 de dezembro de 1964. Dispõe sôbre o condomínio em edificações e as incorporações imobiliárias.

BRASIL. Lei $\mathbf{n}^{\circ} \mathbf{4 . 7 7 1}$, de 15 de setembro de 1965. Institui o novo Código Florestal.

BRASIL. Lei $\mathbf{n}^{\circ} \mathbf{6 . 0 1 5}$, de 31 de dezembro de 1973. Dispõe sobre os registros públicos, e dá outras providências. 
BRASIL. Lei $n^{\circ}$ 6.216, de 30 de junho de 1975. Altera a Lei no 6.015, de 31 de dezembro de 1973, que dispõe sobre os registros públicos.

BRASIL. Lei $\mathbf{n}^{\circ}$ 6.383, de 07 de dezembro de 1976. Dispõe sobre o Processo Discriminatório de Terras Devolutas da União, e dá outras Providências.

BRASIL. Lei $\mathbf{n}^{\circ}$ 6.602, de 07 de dezembro de 1978. Altera a redação da alínea i do artigo $5^{\circ}$ do Decretolei $n^{\circ}$ 3.365, de 21 de junho de 1941, que dispõe sobre desapropriações por utilidade pública, e acrescenta parágrafos ao mesmo artigo.

BRASIL. Lei $\mathbf{n}^{\circ}$ 6.766, de 19 de dezembro de 1979. Dispõe sobre o Parcelamento do Solo Urbano e dá outras Providências.

BRASIL. Lei $\mathbf{n}^{\circ} \mathbf{7 . 5 1 1}$, de 07 de juhlo de 1986. Altera dispositivos da Lei $n^{\circ} \mathbf{4 . 7 7 1}$, de 15 de setembro de 1965, que institui o novo Código Florestal.

BRASIL. Lei $\mathbf{n}^{\circ}$ 8.212, de 24 de julho de 1991. Dispõe sobre a organização da Seguridade Social, institui Plano de Custeio, e dá outras providências.

BRASIL. Lei $\mathbf{n}^{\circ}$ 9.514, de 20 de novembro de 1997. Dispõe sobre o Sistema de Financiamento Imobiliário, institui a alienação fiduciária de coisa imóvel e dá outras providências.

BRASIL. Lei ${ }^{\circ}$ 9.636, de 15 de maio de 1998. Dispõe sobre a regularização, administração, aforamento e alienação de bens imóveis de domínio da União, altera dispositivos dos Decretos-Leis nos 9.760, de 5 de setembro de 1946, e 2.398, de 21 de dezembro de 1987, regulamenta o § 20 do art. 49 do Ato das Disposições Constitucionais Transitórias, e dá outras providências.

BRASIL. Lei n ${ }^{\circ}$ 9.785, de 29 de janeiro de 1999. Altera o Decreto-Lei no 3.365, de 21 de junho de 1941 (desapropriação por utilidade pública) e as Leis nos 6.015, de 31 de dezembro de 1973 (registros públicos) e 6.766, de 19 de dezembro de 1979 (parcelamento do solo urbano).

BRASIL. Lei $\mathbf{n}^{\circ} \mathbf{1 0 . 1 8 8}$, de 12 de fevereiro de 2001. Cria o Programa de Arrendamento Residencial, institui o arrendamento residencial com opção de compra e dá outras providências.

BRASIL. Lei $n^{\circ} \mathbf{1 0 . 2 5 7}$, de 10 de julho de 2001. Regulamenta os arts. 182 e 183 da Constituição Federal, estabelece diretrizes gerais da política urbana e dá outras providências.

BRASIL. Lei $\mathbf{n}^{\circ}$ 10.406, de 10 de janeiro de 2002. Institui o Código Civil.

BRASIL. Lei $\mathbf{n}^{\circ}$ 11.124, de 16 de junho de 2005. Dispõe sobre o Sistema Nacional de Habitação de Interesse Social - SNHIS, cria o Fundo Nacional de Habitação de Interesse Social - FNHIS e institui o Conselho Gestor do FNHIS.

BRASIL. Lei $\mathbf{n}^{\circ}$ 11.445, de 05 de janeiro de 2007. Estabelece diretrizes nacionais para o saneamento básico; altera as Leis nos 6.766, de 19 de dezembro de 1979, 8.036, de 11 de maio de 1990, 8.666, de 21 de junho de 1993, 8.987, de 13 de fevereiro de 1995; revoga a Lei no 6.528, de 11 de maio de 1978; e dá outras providências.

BRASIL. Lei $\mathbf{n}^{\circ}$ 11.481, de 31 de maio de 2007. Dá nova redação a dispositivos das Leis nos 9.636, de 15 de maio de 1998, 8.666, de 21 de junho de 1993, 11.124, de 16 de junho de 2005, 10.406, de 10 de janeiro de 2002 - Código Civil, 9.514, de 20 de novembro de 1997, e 6.015, de 31 de dezembro de 1973, e dos Decretos-Leis nos 9.760, de 5 de setembro de 1946, 271, de 28 de fevereiro de 1967, 1.876 , de 15 de julho de 1981, e 2.398, de 21 de dezembro de 1987; prevê medidas voltadas à regularização fundiária de interesse social em imóveis da União; e dá outras providências.

BRASIL. Lei $\mathbf{n}^{\circ}$ 11.977, de 07 de julho de 2009. Dispõe sobre o Programa Minha Casa, Minha Vida PMCMV e a regularização fundiária de assentamentos localizados em áreas urbanas; altera o DecretoLei no 3.365, de 21 de junho de 1941, as Leis nos 4.380, de 21 de agosto de 1964, 6.015, de 31 de dezembro de 1973, 8.036, de 11 de maio de 1990, e 10.257, de 10 de julho de 2001, e a Medida Provisória no 2.197-43, de 24 de agosto de 2001; e dá outras providências.

BRASIL. Lei ${ }^{\circ}$ 12.305, de 02 de agosto de 2010. Institui a Política Nacional de Resíduos Sólidos; altera a Lei no 9.605, de 12 de fevereiro de 1998; e dá outras providências.

BRASIL. Lei $\mathbf{n}^{\circ}$ 12.424, de 16 de junho de 2011. Altera a Lei $n^{\circ}$ 11.977, de 7 de julho de 2009, que dispõe sobre o Programa Minha Casa, Minha Vida - PMCMV e a regularização fundiária de 
assentamentos localizados em áreas urbanas, as Leis ํㅗ 10.188 , de 12 de fevereiro de 2001, 6.015, de 31 de dezembro de 1973, 6.766, de 19 de dezembro de 1979, 4.591, de 16 de dezembro de 1964, 8.212, de 24 de julho de 1991, e 10.406, de 10 de janeiro de 2002 - Código Civil; revoga dispositivos da Medida Provisória nำ2.197-43, de 24 de agosto de 2001; e dá outras providências.

BRASIL. Lei $\mathbf{n}^{\circ} \mathbf{1 2 . 4 6 5}$, de 12 de agosto de 2011. Dispõe sobre as diretrizes para a elaboração e execução da Lei Orçamentária de 2012 e dá outras providências.

BRASIL. Lei $\mathbf{n}^{\circ}$ 12.587, de 03 de janeiro de 2012. Institui as diretrizes da Política Nacional de Mobilidade Urbana; revoga dispositivos dos Decretos-Leis nos 3.326, de 3 de junho de 1941, e 5.405, de 13 de abril de 1943, da Consolidação das Leis do Trabalho (CLT), aprovada pelo Decreto-Lei no 5.452, de $1^{\circ}$ de maio de 1943, e das Leis nos 5.917, de 10 de setembro de 1973, e 6.261, de 14 de novembro de 1975; e dá outras providências.

BRASIL. Lei n $^{\circ}$ 13.089, de 12 de janeiro de 2015. Institui o Estatuto da Metrópole, altera a Lei oㅜ 10.257, de 10 de julho de 2001, e dá outras providências.

BRASIL. Lei $\mathbf{n}^{\circ}$ 13.645, de 11 de julho de 2017. Dispõe sobre a regularização fundiária rural e urbana, sobre a liquidação de créditos concedidos aos assentados da reforma agrária e sobre a regularização fundiária no âmbito da Amazônia Legal; institui mecanismos para aprimorar a eficiência dos procedimentos de alienação de imóveis da União; altera as Leis n os 8.629, de 25 de fevereiro de 1993 , 13.001, de 20 de junho de $2014,11.952$, de 25 de junho de 2009, 13.340, de 28 de setembro de 2016, 8.666, de 21 de junho de 1993, 6.015, de 31 de dezembro de 1973, 12.512, de 14 de outubro de $2011,10.406$, de 10 de janeiro de 2002 (Código Civil), 13.105, de 16 de março de 2015 (Código de Processo Civil), 11.977, de 7 de julho de 2009, 9.514, de 20 de novembro de 1997, 11.124, de 16 de junho de 2005, 6.766, de 19 de dezembro de 1979, 10.257, de 10 de julho de 2001, 12.651, de 25 de maio de 2012, 13.240, de 30 de dezembro de 2015, 9.636, de 15 de maio de 1998, 8.036, de 11 de maio de 1990, 13.139, de 26 de junho de 2015, 11.483, de 31 de maio de 2007, e a 12.712, de 30 de agosto de 2012, a Medida Provisória ํㅡ 2.220, de 4 de setembro de 2001, e os Decretos-Leis n 2.398, de 21 de dezembro de 1987, 1.876, de 15 de julho de 1981, 9.760, de 5 de setembro de 1946, e 3.365, de 21 de junho de 1941; revoga dispositivos da Lei Complementar oㅜ 76, de 6 de julho de 1993, e da Lei no 13.347, de 10 de outubro de 2016; e dá outras providências.

BRASIL. Lei $\mathbf{n}^{\circ} \mathbf{1 3 . 4 8 5}$, de 02 de outubro de 2017. Dispõe sobre o parcelamento de débitos com a Fazenda Nacional relativos às contribuições previdenciárias de responsabilidade dos Estados, do Distrito Federal e dos Municípios, e sobre a revisão da dívida previdenciária dos Municípios pelo Poder Executivo federal; altera a Lei no 9.796, de 5 de maio de 1999; e dá outras providências.

BRASIL. Medida Provisória no 459, de 25 de março de 2009. Dispõe sobre o Programa Minha Casa, Minha Vida - PMCMV, a regularização fundiária de assentamentos localizados em áreas urbanas, e dá outras providências.

BRASIL. Medida Provisória no 759, de 22 de dezembro de 2016. Dispõe sobre a regularização fundiária rural e urbana, sobre a liquidação de créditos concedidos aos assentados da reforma agrária e sobre a regularização fundiária no âmbito da Amazônia Legal, institui mecanismos para aprimorar a eficiência dos procedimentos de alienação de imóveis da União, e dá outras providências.

BRASIL. Medida Provisória no 2.197-43, de 24 de agosto de 2001. Dispõe sobre a adoção de medidas relacionadas com o Sistema Financeiro da Habitação - SFH, altera as Leis nos 4.380, de 21 de agosto de 1964, 8.036, de 11 de maio de 1990, e 8.692, de 28 de julho de 1993, e dá outras providências.

BRASIL. Medida Provisória no 2.200, de 04 de setembro de 2001. Dispõe sobre a concessão de uso especial de que trata o § 10 do art. 183 da Constituição, cria o Conselho Nacional de Desenvolvimento Urbano - CNDU e dá outras providências.

BRASIL. Ofício da Assembleia ao M. do Império. Rio de Janeiro: Câmara dos Deputados, 20 de outubro de 1823.

BRASIL. Provimento $n^{\circ}$ 18/2012. Dispõe sobre a instituição e funcionamento da Central Notarial de Serviços Eletrônicos Compartilhados - CENSEC.

BRASIL. Provimento $\mathrm{CNJ} \mathbf{n}^{\circ}$ 44/2015. Estabelece normas gerais para o registro da regularização fundiária urbana. 
BRASIL. Resolução ${ }^{\circ}$ 76, de 17 de julho de 1822. De consulta da Mesa Do Desembargo Do Paço de 17 de julho de 1822. Manda suspender a concessão de sesmarias futuras até a convocação da Assembléia Geral Constituinte.

BRASIL. Resolução Concidades no 34, de 01 de julho 2005. Orientações e recomendações quanto ao conteúdo mínimo do Plano Diretor. Disponível em: http://www.cidades.gov.br/images/stories/ArquivosCidades/ArquivosPDF/Resolucoes/resolucao-342005 alterada.pdf. Acesso em: 10 jun. 2018.

BUCCI, Mário César. Parcelamento do Solo: loteamento. Campinas: Editora Jurídica Mizuno, 1998.

COSTA NETO, Joaquim de Britto. A questão fundiária nos parques e estações ecológicas do Estado de São Paulo: origens e efeitos da indisciplina da documentação e do registro imobiliário. São Paulo: USP, 2006. p. 07-54. Tese (Doutorado em Estruturas Ambientais Urbanas) - Faculdade de Arquitetura e Urbanismo, Universidade de São Paulo, São Paulo, 2006.

DEAN, Warren. Rio Claro: um Sistema Brasileiro de Grande Lavoura - 1820-1920. São Paulo: Paz e Terra, 1977. In: GADELHA, Regina Maria d'Aquino Fonseca. A lei de terras (1850) e a abolição da escravidão: capitalismo e força de trabalho no Brasil do século XIX. Revista de História, São Paulo, v. 120, p. 153-162, jan/jul. $1989 . \quad$ Disponível em: http://www.revistas.usp.br/revhistoria/article/view/18599/20662. Acesso em: 24 fev. 2020.

DIADEMA. Lei Municipal no 975, de 03 de novembro de 1988. Desafeta áreas municipais e autoriza a outorga de concessões de direito real de uso independentemente de prévio procedimento licitatório à moradores de favelas e dá outras providências.

FERNANDES, Edésio. Regularização fundiária plena: referências conceituais. Brasília: Ministério das Cidades, $2006 . \quad$ Disponível em: http://www.urbanismo.mppr.mp.br/arquivos/File/Livro Regularizacao Fundiaria Plena Referencias C onceituais.pdf. Acesso em: 20 fev. 2020.

FERREIRA, Waldemar. O Loteamento e da Venda de Terrenos em Prestações. Revista dos Tribunais, São Paulo, v. 1/116, p. 99 - 124, 1938.

GARCIA, Graciela Bonassa. Registros Paroquiais de Terras. In: MOTTA, Márcia; GUIMARÃES, Elione (Orgs.). Propriedade e disputas: fontes para a história do oitocentos. Niterói: EDUFF, 1‥ edição, 2011, p. 65-67.

HOLSTON, James. Legalizando o ilegal: propriedade e usurpação no Brasil. Revista Brasileira de

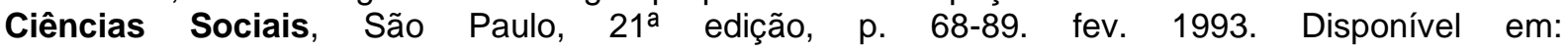
http://www.anpocs.com/images/stories/RBCS/21/rbcs21 07.pdf. Acesso em: 24 fev. 2020.

KÜMPEL, Vitor Frederico. Evolução histórica da atividade registral imobiliária no Brasil e o surgimento dos princípios registrais. Disponível em: https://www.migalhas.com.br/coluna/registralhas/179743/evolucao-historica-da-atividade-registralimobiliaria-no-brasil-e-o-surgimento-dos-principios-registrais. Acesso em 15 nov. 2019.

LACERDA, Manoel Linhares de. Tratado das terras do Brasil. Rio de Janeiro: Alba, 1960. v. 1, 870 p.

LEONELLI, Gisela Cunha Viana. A construção da lei federal de parcelamento do solo urbano 6.766: debates e propostas do início do séc. XX a 1979. São Carlos, Universidade de São Paulo, 2010. Tese (Doutorado em Teoria e História da Arquitetura e do Urbanismo) - Escola de Engenharia de São Carlos, Universidade de São Paulo, São Carlos, 2010.

LOPES, Cacilda. As influências das legislações de Parcelamento do Solo na produção dos espaços urbanos. São Paulo: PUC-SP, 2001. Dissertação (Mestrado em Direito do Estado) - Pontifícia Universidade Católica de São Paulo, São Paulo, 2001.

MAGALHÃES, Alex Ferreira. O Instituto da "Legitimação de Posse" no Direito Brasileiro. 1997. Monografia conclusiva (Mestrado em Direito da Cidade) - Universidade Estadual do Rio de Janeiro, Rio de Janeiro, $1997 . \quad$ Disponível em: http://www.angelfire.com/ut/jurisnet/art71.html\#: :text=O\%20instituto\%20da\%20legitima\%C3\%A 
7\%C3\%A30\%20de\%20posse \%20surge \%2C \%20formalmente\%2C\%20no\%20direito,terras $\% 20$ devolu tas\%20do\%20lmp\%C3\%A9rio\%20brasileiro. Acesso em: 11 jun. 2018.

MARICATO, Ermínia. As idéias fora do lugar e o lugar fora das idéias: Planejamento urbano no Brasil. In: ARANTES, Otília; VAINER, Carlos; MARICATO, Ermínia. A cidade do Pensamento Único. Petrópolis: Vozes, 2002. p. 15-16. 3를 $\mathrm{ed}$.

MARICATO, Ermínia. Brasil, cidades: alternativas para a crise urbana. Petrópolis: Vozes, 2018. p. 16.

MARTINS, Maria Lúcia Refinetti. Moradia e Mananciais: Tensão e Diálogo na Metrópole. São Paulo: Maxprint Editora e Gráfica, 2006. 205 p.

MEIRELLES, Hely Lopes. Direito Municipal Brasileiro. Revista dos Tribunais, São Paulo, $3^{a}$ edição, p. 621-622, 1977.

MEIRELLES, Hely Lopes. Direito de Construir. São Paulo: Editora Malheiros, 1996.

MENDES, José Sacchetta Ramos. Desígnios da Lei de Terras: imigração, escravismo e propriedade fundiária no Brasil Império. Caderno CRH, Salvador, v. 22, n. 55, p. 173-184, abr. 2009. Disponível em: http://www.scielo.br/scielo.php?script=sci arttext\&pid=S0103-49792009000100011\&lng=pt\&nrm=iso. Acesso em: 23 fev. 2020.

MIRANDA, Pontes de. Tratado de Direito Predial. São Paulo: Bookseller Editora, 1955.

MIRANDA, Pontes de. Tratado de Direito Privado. São Paulo: Bookseller Editora, 1957, tomo XIII.

OLIVA, Jaime Tadeu; FONSECA, Fernanda Padovesi. O "modelo São Paulo": uma descompactação antiurbanidade na gênese da metrópole. Revista do Instituto de Estudos Brasileiros, São Paulo, № 65, p. 20-56, dec. 2016. Disponível em: http://www.scielo.br/scielo.php?script=sci arttext\&pid=S002038742016000300020\&lng=en\&nrm=iso. Acesso em: 01 mar. 2020.

PASTERNAK, Suzana; D'OTTAVIANO, Camila. Favelas no Brasil e em São Paulo: avanços nas análises a partir da Leitura Territorial do Censo de 2010. São Paulo, Cadernos Metrópole, 2016. v. 18, n. 35, p. 75-100. Disponível em: http://cadernosmetropole.net/artigo/334. Acesso em: 29 jun. 2018.

PEREIRA, Antônio Francisco. Sentença revolucionária em ação de reintegração na posse contra semterra. Revista Jus Navigandi, Teresina, ano 3, n. 27, dez. 1998. Disponível em: https://jus.com.br/jurisprudencia/16339. Acesso em: 21 fev. 2020.

PORTUGAL. Carta Régia dirigida ao governador e capitão do Estado do Brasil. Lisboa, 20 de fevereiro de 1695.

PORTUGAL. Lei de Sesmarias. Santarém, 28 de maio de 1395.

SÃO PAULO. Decreto no 33.499, de 10 de julho de 1991. Cria Grupo de Análise e Aprovação de Projetos Habitacionais - GRAPROHAB e dá outras providências.

SÃO PAULO. Lei Municipal $\mathbf{n}^{\circ} \mathbf{7 . 6 8 8}$, de 30 de dezembro de 1971. Dispõe sobre a instituição do plano diretor de desenvolvimento integrado do município de São Paulo - PDDI - SP, e dá outras providências.

SÃO PAULO. Lei Municipal $\mathbf{n}^{\circ} \mathbf{7 . 8 0 5}$, de $1^{\circ}$ de novembro de 1972 . Dispõe sobre o parcelamento, uso e ocupação do solo do município, e dá outras providências.

SÃO PAULO. Projeto de Lei Complementar $n^{\circ}$ 12/2017. Dá nova redação ao artigo $2^{\circ}$ do Capítulo VI da Lei Complementar no 1.261, de 2015, para prorrogar o prazo de apresentação do Projeto de Lei Revisional dos Municípios Turísticos. Publicada em: 12 mai. 2017.

SÃO PAULO. Provimento $\mathbf{n}^{\circ} \mathbf{9} / \mathbf{8 0}$. Dispõe sobre comuoicaçio ao distribuidor, a requerimento do interessado, de decisio que ponha fim ao processo.

SÃO PAULO. Provimento $\mathbf{n}^{\circ} \mathbf{2 / 8 2}$. O Doutor JOSÉ DE MELLO JUNQUEIRA, MM. Juiz de Direito da Primeira Vara de Registros Públicos da Comarca da Capital e Corregedor Permanente dos Cartórios de Registro de Imóveis da Capital, no uso das atribuições que lhe são conferidas por Lei (...).

SÃO PAULO. Provimento n 3/82. O Desembargador Bruno Affonso de André, Corregedor Geral da Justiça do Estado de São Paulo (...). 
SÃO PAULO. Provimento $\mathbf{n}^{\circ} \mathbf{5 8} / \mathbf{8 9}$. O desembargador Milton Evaristo Dos Santos, Corregedor Geral da Justiça do Estado de Säo Paulo, no uso de suas atribuições legais (...).

SÃO PAULO. Provimento CG no 21/2013. O Desembargador José Renato Nalini, Corregedor Geral da Justiça do Estado de São Paulo (...).

SÃO PAULO. Provimento CG no 37/2013. Modifica o Capítulo XX, do Tomo II, das Normas de Serviço da Corregedoria Geral da Justiça. O Desembargador José Renato Nalini, Corregedor Geral da Justiça do Estado de São Paulo, no uso de suas atribuições legais (...).

SÃO PAULO. Provimento CGJ n 51/2017. Altera os Capítulos XIII e XX e acrescenta a Seção XIII às Normas de Serviço da Corregedoria Geral da Justiça

SÃO PAULO. Provimento CGJ n $56 / 2019$. Atualiza o Tomo Il das Normas de Serviço da Corregedoria Geral da Justiça - Serviços Extrajudiciais de Notas e de Registro do Estado de São Paulo.

SARTORETTO, Ana Lúcia Callari; HERNANDES, Claudia Emilia David; LUZ, Mariana Monteiro de Andrade. Regularização de loteamentos no município de São Paulo: aplicação pioneira da demarcação urbanística. In: NALINI, José Renato; LEVY, Wilson. Regularização Fundiária: de acordo com a Lei 12.615/2012. Rio de Janeiro: Forense, 2013.

SAULE JR., Nelson. A Proteção Jurídica da Moradia nos Assentamentos Irregulares. Porto Alegre: Sérgio Antonio Fabris, 2004.

SILVA, Carlos Eduardo F. da; SÉRIO, Francisco Corrêa. Considerações patrimoniais e fundiárias para a criação de unidade de conservação da natureza. In: IV CONGRESSO BRASILEIRO DE DEFESA DO MEIO AMBIENTE, 4., 1995, Rio de Janeiro. Anais [...]. Rio de Janeiro: Instituto de Engenharia/Universidade Federal do Rio de Janeiro, 1995. p. 100-109.

SILVA, José Afonso da. Curso de Direito Constitucional Positivo. São Paulo: Malheiros, 2017, 40aㅗ ed.

SMITH, Roberto. Propriedade da terra e transição: estudo da formação da propriedade da terra e transição para o capitalismo no Brasil. São Paulo: Brasiliense, 1990.

TIERNO, Rosane de Almeida. Legitimação de Posse e Legitimação Fundiária na Lei Federal $n^{\circ}$. 13.465/2017. In: MENCIO, Mariana; LEITE, Luis Felipe Tengon Cerqueira (Orgs.). Regularização Fundiária Urbana: Desafios e Perspectivas para a Aplicação da Lei $n^{\circ}$. 13.465/17. São Paulo: Letras Jurídicas, 2019. p. 425-452.

TIERNO, Rosane de Almeida. REURB em Áreas de Preservação Permanente: análise da compatibilidade das normas no ordenamento jurídico diante das disposições trazidas pela Lei $\mathrm{n}$. 13.465/17. Revista brasileira de direito urbanístico, Belo Horizonte, v. 6, p. 16-44, 2018.

TONE, Beatriz Bezerra; FERRARA, Luciana Nicolau. Notas sobre a Produção da Irregularidade no Espaço Urbano em São Paulo. In: BÓGUS, Lúcia Maria M; RAPOSO, Isabel; PASTERNAK, Suzana. Da Irregularidade Fundiária Urbana à Regularização: Análise Comparativa Portugal - Brasil. São Paulo: EDUC - Editora da PUC, 2011. p. 314-315.

VALENTE, Gilberto. As Prefeituras Municipais e a Regularização dos Loteamentos. São Paulo: Biblioteca do Instituto de Registro Imobiliário do Brasil, 2003. Disponível em: https://irib.org.br/obras/226. Acesso em: 21 fev. 2020. 